eva Cove. eva

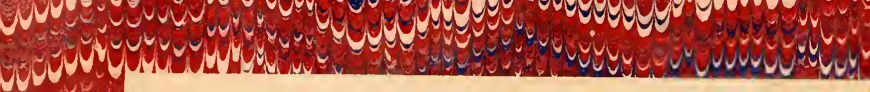

\section{veyzy}

Noy yove Yyou yes (ate $20 y^{2}$ wyyy yy $y=9$ $y=y$ Wut yory pryas ay cove yoy.

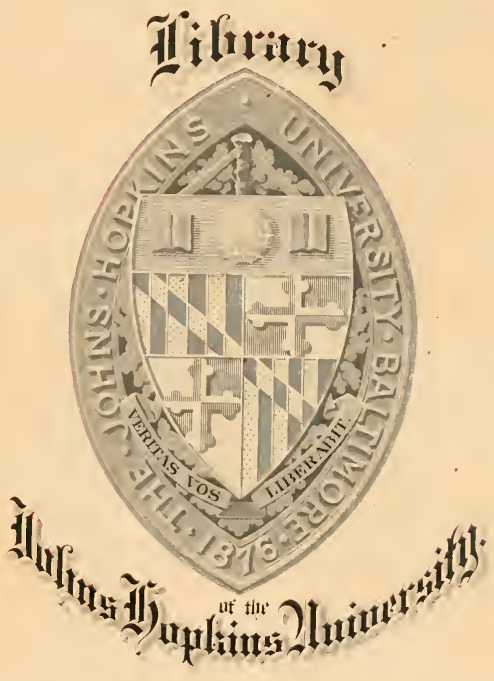

ve $y=y$ was

\section{5}

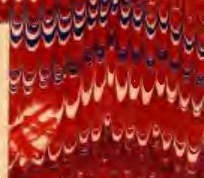

yoy you

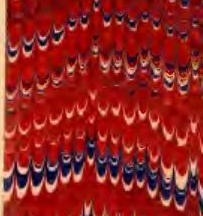

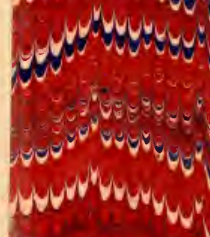

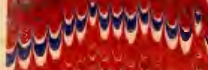

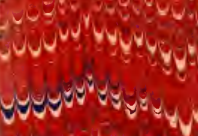

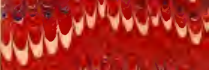

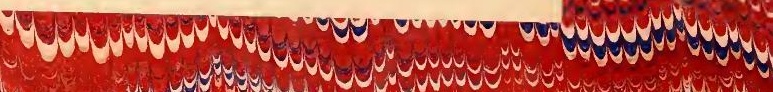

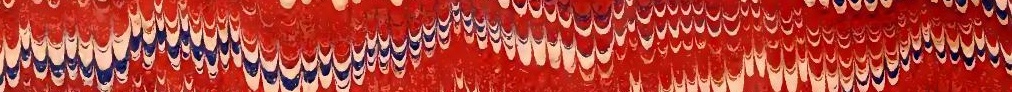

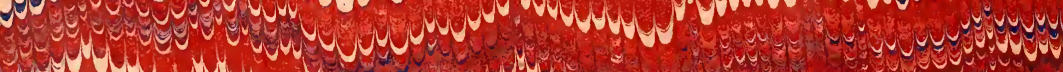
Cy ye 
axy 

, 





$$
\text { - }
$$






THE NEURONES ANU BUPPORTING LEEUENTS OH THE BRAIN OH A BELABHIAN

\author{
A Dissertation \\ Submit tel to the Board of University Studies \\ of the Joins Bopkins. University for the \\ Degree of Doctor of Philosophy
}

$B Y$

GILBERT LOgAN HOUSER

Baltinore

1301 
98105 


\title{
THE NEURONES AND SUPPORTING ELEMENTS OF THE BRAIN OF A SELABMIAN
}

\author{
BY \\ GILBERT L. HOOSER \\ Professor of Animal Yorphology in the University of Iowa \\ $-0--$ \\ Nith Plates I-VIII. \\ $--0--$
}

TABLE OH CONTENTS

Section II. REVIEW OF EARLIER RESEARCHES . . . . . 6

1. Anatomical Nork Involving Errors of Interpretation 6

2. Work on the Microscopical Anatomy of the Brain 9

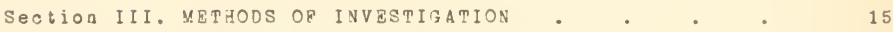

1. Chrome-Silver Inpregnation . . . 15

2. The Application of Methylen-Blue . . 17

a. The Staining Vethod of Nissl . . . 17

b. Intra-Vitum Injection . . . . 19

3. Iron Haematoxylin . . . . . . 21

4. The Chloride of Vanailum Methoi . . . . 22

Section IV. THE OBLONGATA . . . . . . . . . . . 23

1. General Morphology of the Oblongata. . . 23

2. Reviex of Nerve Components . . . . . 26

3. Neurones of the Ventral Cornu . . . . 32

a. Tract-Neurones . . . . . . 32 

b. Comaissural Neurones . . . . . 35

4. Lobus Vagi and Fasciculus Communis . . . 37

a. Neurones of the Lobus Vagi . . . 37

b. Termination of Communis Pibres . . . 39

○. The Rasciculus Communis.. . . 4 40

5. The Viscero-Motor Nucleus . . . . 41

B. General Cutaneous Nucleus and Spinal V Tract 44

a. The Molecular Layer . . . . . 45

b. The Substantia Gelatinosa . . . . 46

c. The Deeper Neurones . . . . . 4 48

d. Termization of General sutzneous Fibres. 50

7. The Tuberculum Acusticum . . . . . 52

a. Molecular and Granular Neurones . . . 53

b. Purkinje Neurones . . . . . . 54

c. Ternination of Acustico-tateral Fibres . 55

d. Theoretical Conclusions . . . . 56

8. Supporting Elements . . . . . . . 58

a. Ependyma . . . . . . . . . 58

b. Neuroglia . . . . . . . . . 59

9. Sumnary of the Oblongatz . . . . . 61

Section V. THE CEREBELLUM . . . . . . . . . . . 63

1. The veurones of Purkinje . . . . . 64

2. The Molecular Layer . . . . . . . 68

3. The Granular Layer . . . . . . 71

a. Granular Neurones Proper . . . . 71

b. Golgi Neurones . . . . . . 73

4. Supporting Elements . . . . . . . 74

a. Epenjyma

b. Neuroglia . . . . . . . . . 76

5. Arohitectur and Physiology of the Cerebellum. 79

6. Evolution of the Cerebellum . . . . . 82

7. Sumnary of tbe Cerebellum . . . . . 85

Section VI, THE MIDBRAIV . . . . . . . 87

1. The Tectum Mesencephali . . . . . . 88

a. Ternination of the Optious. Str.Melul.Profun.89

b. The Superficial Neurones . . . . 91

c. The vidile veurones . . . . . 91 

d. The Deoper Neurones . . . . 93

2. The Central Gray Matter . . . . . 96

a. The Rool-Nucleus . . . . . 96 96

b. The Nucleus of the Oculomatorius . . .102

c. The Nucleus of the Trochlearis.. . 103

3. The Ependyma . . . . . . . . . 105

4. Phylogeny of Midbrain Structuras . . . $10 B$

5. Sumary of the Midbrain . . . . 107

Section VII. THE INTERBRaIN . . . . . . . . 110

1. The Thalamus . . . . . . . . 110

a. Nucleus Strati Grisei . . . . . 111

b. Nucleus Geniculatum . . . . . 113

2. Epithalamas: The Nucleus Habonulae . . . 114

3. Hypothalamus: The Lobi Inferiores . . . 115

4. Supporting Elgments . . . . . . 119

5. Summary of the Interbrain . . . 118

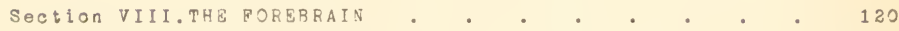

1. The Olfactory Lobe . . . . . . 122

2. The Striztim . . . . . . . 123

a. Epistriatum . . . . . . . . 123

b. General Striatam . . . . . . 125

c. Nucleus Postolfactorius . . . . 128

3. The Nucleus Neuroporicus . . . . . 128

4. The Pallium . . . . . . . 131

a. Neurones of the Tractus Pallii . . . 132

b. Associative and Comissural Neurones . 134

c. Cajal Neurones . . . . . . . 134

1. General Consilerations on the Pallium . 136

5. Supportizg Elenents . . . . . . 138

6. Summary of the Rorebrais . . . . . 139

Section IX. GEVERAL SOMMARY ANJ CONCLUSION $\quad . \quad$. $\quad . \quad 141$

Section $X$. LITHRATJRE CITEJ . . . . . . . . 149

Section XI. DESCRIPTION OR THE RIGURES . . . . . . 160 



\section{SECTION I.}

InTRODOCTORY.

The student of mammalian neurology has his attention fixed on mechanisn of surpussing complexity. In the parsuit of his rork, he is continatly touchins problems, both morpholosical anl physiologicql, which feequently transcenl all his porers. But the complex nervous skein which he seeks to unrivel is merely the final nember of a series raaching backwarl through ever simpler and simpler conditions to the organization of the primitive vertebrate. In other words, the mammalian brain is the product of endless rodifications wrought in the orisinal plan of structure by the continual atjustment of nervous mechanisms to the play of a shifting environment. What the arohitecture of the ancestral vertabrate nervous system may have been re can never hope to know fror actual observation. Fortunately, there are simple vertebrates existing to-day wich rətain many features of primitive nervous orsanization. To such animals, the student of neurology must ever turn for the solution of the problens which vex him in hisher fields. One of these simple vertabrates is represented by a selachian of the moder seas, someshat specializad in certain directions, 

of course, but retaining, withyl, much of the archaic nervas orsunization from which highar bruins have been gralually evolved. A study of such a simple brain as that of a selachias constitutes, tharefore, a necessary introduction to the more hiphly differentiated nervous systems of biris and manmals.

Our knowledge of the nervous system is so peculiarly dependent upon methols of investigation that the conceptions held by us might 2 most be saix to Eron out of the teahnique employed. The developnent of neurolosical methots daring the last fen years has been indeed phenomenal, and with this advance there has come tha necessity for a re-investigation of many nervous systems. The rasults obtained by the earlier observers, while praisenarthy in themsalvas, simply do not furnish the precise and complete pictures of neurones which moder comparative neurology requires. And hence it is that the writer has attacked anew the structural problems of $\Rightarrow$ brain which has by no means escaped the attantion of investigators. The phylosenetic value usually assigned to the Selachii has caused many to examine the brain of the shark, both anatomically and microscopically. A historicul roview of the latter class of researches $x i l 1$ be found in Section II, 2 .

The results set forth in this paper ure intended to further axact knoxlexşe concernins the external morpholosy, the internal orsanization, and the architectural relations of the selachian neurones, while also ailing, it is hoped, in the elucidation of certiin questions of a general character. The particular selz- 
chian solecter, Mustelus canis of DeKay, is one in which are combined a structure eqirly representative of the Selachii as I whole, a size convenient tor work, and availability in sufficient numbers to meet the rigorous demands of certin methols of investißुgtion.

This rasearah was begun at the Marine Eiological Laboratory of Woods Holl, where two seasons kere spent in the use of an abundance of living material. The principal stuly Nas continued at the Iniversity of Iona as my regular duties pernitted; while certain collateral lines were followed in the neurological laboratory of the Iniversity of Chicago. A short preliminary notice of the most important results then in hand was published in the Proceedinşs of the Iona Academy of Sciences, Volume IV. The resezrch has finzlly been brought to completion in the biological laboratory of the Johns Hopkins Iniversity.

It is a resl pleasure to acknowledje ny intebtedness to the officials of the Marine Biolosical Laboratory for courtesies extending over a period of several yaars; and to Professor Brojks, I cannot to less than express ny sincere appreciation of the nunerous helpful suggestions given me laring the completion of my nork. 

ZFCTION II.

KEVIH,h OP EARLIK.F RESKAFCHKS.

\section{Anatonical Work Inucluing Errors of Interpretation.}

To trace the history of a misconceptior is a task upon which tew can enter with even the least degree of enthusiusn, but it is necessary for us to notice briefly here certain erroneous viexs which have held sway relstive to the homolopies of the parts of the selachian krain. The interkrain, and alonf with it the midtrain and often the cerebellum as well, have been variously interpreteo ky the investigstors of the last three decades. Niclucho-Naclay ('70) was the first to lreak away from the established teachings of vonEaer ('g7) concernire the possible homologies of the severyl krain-segments. Overlookins, in effect, the true intertrain entirely, since he refarded it as nothing more than a longitudinal comissure, Nicluctokaclay identified the zoischenlim in thot segment which we know as the aidtrain; the cerebellum, beinf next in the longitudiral series, consequently stood for his mi titlhim; while he found his hinterhipn in the small inferior lote of the true cerehellum. Such an interpretation appears slmost inexilj(atle to us, tut ne must not allow ourselves to forfet that the homol- 
ofies so confidently traced by us to day are frounded on many neurolofical studies, the results of whict were not availatle t.o the investigators of the earlier veriod.

Unfortunatelp for comparative anatomy, the conclusions of Niclucho-Naciay nere accepted ky Gesenbsur, and Nere incorpor.ated by him in the seconà edition of his Grundzïge ('70), and were continued in the smaller Grundriss ('74). Appearing also, of course, in the French translation of the former work by Voet, and in the EnElish translation of the 1atter ky Eell, the errors were, througt these several channels, given the widest possicle jistribution amon investigator.s, nith all the prestife of Gecentaur's authority tehind them. Gecenbaur has rectilied the mistake in the latest form assumed by his text-kook ('98), but it probatly will be many years tefore the mischief is fully undone.

Stiedz ('7z) devoted himself' to a correcition of the erroneous conceptions promulgated by diclucho-haclay and Gegenbaur. After carefully consilering the sukject-matter at issue, he embodied his conclusions in a tatle in which the homologies of the several train-segments are properly set for.th. The work of this author had the effect, at least, of directing the attention of anatouists once more to the fact that the homolofies of the fisl-brain were reslly in question, resultirf, ultimately, in the true interpretation prevailing at the present time.

Rohon ('77), althouch writiug several years after the 

publication of Stieda's pafer, sil not fully accelt the work of that author, but took a fosition almost between the errors of Niclucho-Haclay on the one hand, and the truth on the other. Thile Eivine the cerebellun its proper recontition as a brainsegment, he apparently annexed his regio ventriculo terti $i$ to the forebrain, thus leaving the midtrain standing for two whole segments. His zuigchenhirn, therefore, embraced the dorsil portion of the oftic lokes above, and the hypothalanus below; while he located the mittelhim between and kehina these tno divisions of his zwischentipn. Such an interpretation was certainly renarkakle for the incenuity witr which a place was found where sn error bifht te lodgej, but it was almost, if not guite equaled by the Eeneral homologies drawn by Fritsch ('75), who took the whole milkrain for a seconatry vorlerkirn. These several errors, curious as some of then certuinly are, wifht hav little more than a passing interest for us to day, were it not that they continue to reappear at intervals, tingin the work of those making claims to a certain degree cf authorit»tive treatment. As an instance of tris kinj, it may be noted that one of our most recent treatises on comparative anstory contains a fifure of the selachian trair witr the cerebollun jesigrated lobe ortique, and the anterior end of tre oblongaty the cervelet*.

* Roule, I; L'Anatorie Comparé́ des Animaux, Tome 2, Pig.1137. Paris, 1888 . 



\section{Nork on the Vicroscopical Anatomy of the Erain.}

Anatonical work on the nervous system of the Selachii was beģun relatively early, but nicroscopical study laffed somenhat behind that on the kony fishes. One of the earliest researches touchine the microscopjcel structure of the selachiar brain was that of Leydif ('52). This versatile investigator was enfaged in tracing the seneral orsanogeny and histology of the rays sna sharks, anà so his work upon the train was not special in its character. Here, however, he discovered the olfactory Eloneruli, a result altoøether sufficient in itself. Of course, the nature of the microscopical methods then in use did not permit Leyaic to see much more than the general outline of a Elomerulus and the fibres associsted therewith. It remained for later norkers to trace the full significance of his discovcr.y.

The two decades following the research of Leydif witressed the unfolding of the germ of a special neurolofical technique. Stilling had introduced the method of studying the krain ty means of sections as early as 124z, but the great gavantafes to be derived fron stainiug the sections nere not realized until 1958, when Gerlach soaked his sections in a solution of carmine. Later, 1872, Gerlach obtained such briljjant results witr gold chlorjde as to lesa to wany trials witr this reafent, while some of the possibilities of osmic acid were Elso becomine known. Firraly, chromic acid and the tichroastes had come 

to be recopnized as valuatle means for tardening nervous tissues. Fortunate that nan who was permitted to contrikute to the inauguration of a new era in the comparative study of the nervous systen, the era of microscopicel research. Tro investisators extended such a possibility to the field of the selachian train at practically the same time, Viault puklishing his results in 1876, and frohon in 1877.

The research of Vitult ('re) is quite troad in its scope. It includes a review of the anatonical features of the selachian nervous systen; a description of the structural elements common to all nerve-centres; toporraphic histology, or the structure of the severyl parts of the brain and cord; and, finally, a consideration of the homologies of the brain-segments. The figures xhich accompany the paper are perfectly clear in their execution, but they represent such a low degree of magnification that they are really little more than diarrans. While the otservations recorded by this author are of the nost general character, he should receive great creait for juterpreting the brain-segments properly at a time when there was much confusion in this respect.

In the prosecution of his resesrch, Rohon ("rin) had all the stimulating advantages of the latoratory of claus, and his work has 2 hioh order of merit. There is a section devoted to the compargtive anatony of the cranisl rerves and the several regions of the train, in toth the rays and the sharks. Certain figures illustrating this portion of the work are taniliyr to 

all comparative anatomists throukh their reproduction in the text-books. The histolopical portion of the research is carefully written, and it is clear thyt the writer had seen all that the technique of the period would demonstrate. Ne find in his figures, therefore, nerve-cells represented with some detail of structure, nerve-tibres showing some connection with particular groups of nerve-cells, and fitre-trocts which trke a certain definiteness in their courses. The most noteworthy discovery made by Eohon was the dachkerne of the midtrain; see Section VI. But the Ereatest service which he bas rendered consisted in his pointing out for the first time the many structural teatures which the brain of the selachian has in common Nith the organization of hicher vertebrate trains.

The next research which we have to notice is that of Sanders $\left(8^{2}\right)$. Ihis author seems not to have been familiar with the Ereat advances just made in methoas of research, (see infra); and so we find him rejecting carmine as a staining medium and expressing a preference for rosaniline because of the clearness of the pictures yieljed by it, while he Eives a mere hint of haematoxylin. The scale of the work is ambitious to a defree bordering on superficial treatment. There are to be included the anatomy and histology of the brain, spinal cord, and cranial nerves in both the rays and the sharks. The histolofical descriptions usually embrace the Eeneral distrilution of the nerve-cells of a Eiven recion, followej by exhaustive measurements of their sizes. His fíures are harjly more than outlines of brgin- 
sections, exhibiting very little detail. His most Erievous mistake lay in his refusal to apply the brilljant Eeneralizytion on the pallium which Fabl-Fückhard ('88) had putlished sbortly beiore, rejectinf it as an impossible explanation of the selachian forebrain.

We now turn to the work of an investifator whose privelege it has been to lay many of the stones for the foundation of comprative neurology. Dr. Edinger has demonstrated that it is possible to carry on research in the right way in spite of the exhausting cares of a physician's life. His earlier work ('98) includes the consideration of toth the embryonic and sdult selachian forebrair as a part of a systematic stuay of the forebrain of the several Eroups of vertebrates. By this time there had been छiven to neurolosical workers two of the most important methods of investigation yet inasined, the chromesilver imprẹnation of Golpi, and the mvelin stain of Tieicert. The former has led, ultintely, to the modern conception of the neurone as a structural and physiolosical unit; while the latter, including bere the various modifications of the essential principle, has §rounded our knowledge of the course of nerve-fibres in the cerebrospinal axis. In the research under consideration, ('88), Exinger was the first to apply the staining method of Neigert to the brain of the selachian. Using a counter-stain to define the nerve-cells more clearly, his results were characterized by a precision not known to the earlier workers. The chief part of the text is occupiej by 1 description of the 
fibre-tracts, ana the drawings are evidently intend do illustrate this phase of the subject slone. The nerve-cells are Jescribed as to distritution and Eeneral external morphology, so far as they are male visible by the method employed. The principal sim of the research is an elucidation of tibre-tracts rather than the investigation of nerve-cells.

In a later research ('g2), Eidinger applied essentially the same nethods to the interbrain of selachians and amphibians, and the results have a scope similar to those just noticed for the forebrain. In the later editions of his text-book (1900) he has amplified ior the conpsrative portion of the nork the results of 211 his own stuaies, together with those of others, giving us the troadest exposition of moder.n comparative neurology yet attenpteว by any writer.

To Sauerbeck (' $g$ f ) belongs the credit of first publishing results from ths application of chrome-silver impregnation to the selachian brain. The paper contains a very trief description of those neurones and supportine elements which had been impresnated; by far the greater number of the structures present evidently were not demonstrated at all. The treatment is quite unequal for the several regions, and the figures are drawn on a small scale. Thile Sauerbeck must not be छiven credit for the thines he neither described nor portrayed, yet a first attempt in this tield is certuinly to be commended.

$$
\text { Schaper ( } g e \text { ), in the course of } a \text { series of studies on the }
$$
ceretellun of vertetrates, has taken occasion to afply the 
chrome-silver method to the selachian cerebellum. His paper records observations with a considerable defree of detail. Reference to the results of Schaper will te arde more particularly under Section $V$.

Inspired by the elaborate classification of nerve-cells in general promulgated by Nissl in his writings, Szczawinska ('98) жаs impelled to make a study of the internal structure of the selachian nerve-cell. His work fresents the results of his researches upon certain types of cells through the use of methylen-blue, safranin, and haematoxylin stairs. The cells studied were from the sensory छangliz, notor cells from the cord and oblongata, and cells of Purkinje from the cerebellum. Szczawinska reached the conclusion that the nerve-cells of selachians have remainej on a low plane of development. In support of this view he cites certain ol his results _. (1) that the cell-todies are usually ti-polar in form; (z) that there is but slight demarcation between the cell-body and its protoplasmic processes; and ( 3 ) that the chromophile substance is less differentiated than in teleosts and hisher vertetrates. 



\section{SECTION III. \\ VETHODS OR INVESTIGATION.}

The technique employed in the course of this research has covered a wide range. In fact, every process holding any pronise of value has been given a careful trial. It seems desirable to descrjbe here, however, only those methods which have contrituted most largely to the firal results.

\section{Shrome-Silver Impregnation.}

The projuction of a chrone-silver deposit in nervous elements is far more than a simple chemical reaction between the potassium bichromate and the silver nitrate employed. There is to be added as a prine factor, the chemistry of the nervous tissues themselves. The sutstances present in the nervous elements enter into the reaction to such $\approx$ desree that the results are either positive or nesative according to the character of those sutstances. In the economy of the animal, serving both as the basis for nervous activity and produced as the result of it, there is a constant round of netabolic change altering the chemical composition of the nervous tissues. In my work 

upon Mustelus, it was soon found that stricit account lsad to te taken of the physiological state of the animal. An individual f'resh from the pursuit of his prey in the open sea Eave altoEether different results from one which had been kept for some tine in a small aquariud, simply because the reactions of the tissues in the two instances were quite diflerent. And so, before even fij results with chrone-silver inurefnation coulj be secured, it was necessary to make a. careful study of physiological conditions.

It ras also found that selachian nervous elements lenj themselves but @ruß̊inEly, at best, to the reaction desired. Numerous trials nere nade of the several published schemes for securine imprẹnation, but particularly of the procedure indicated by Golgi ('94); by kanon y Cajal ('94); by Flechsig ('89); by Cox ('91); and by Strong ('95, '9e). Ivery application practicatle was also made of formaldehyde as a constituent of the reasents employej. A general critique of these processes has already been હiven by me in a former paper ('97a). The slices oi periectly fresn brain from the most active snimsl procuratle were placed in the "rapid" hardeninf nixture of Golgi. The pieces were always small, not over two millimeters in thickness for, e.q., a transverse section of the forebrain. The proportion of the hardeninE fluid usej embraced one part of 19 osmic acid to four parts $=.59$ potassiun bichromate, and this reacent was usej in liberal quantities. The proper durution of hardeninf $x_{a s}$ intluences by the tempersture of the 
room and the physiological state of the aninal, but an average length of time was three days. The Ereatest clearness of imprefnation was secured with silver nitrate solution of $0.75 q$ strength. In the preparation of serial sections, the most aesiratle clearing asent was found in a mixture of oil berpsmot, oil cedarNood, and melteả cartolic acid crystals, equal parts. After. being hardened in chlorolorm, the celloidin tlocks were placed in the clearine mixture, and they were kept flooded with the oil Juring cutting. The arove mixture clears the block rapid1y, it nay be usej repeatealy, and it has the additional advantage of allowing the preparations to be kept in it for some time without impairing the impresnation. The sections were cut 75 micra in thickness.

\section{The Application of Vethylen-Elue.}

Nethylen-blue holds so many possibilities as a neurological reagent that we are douktless but crossing the thresholj of its use to ày. I have appljed tbis aniline in every way of which I could learn, and the most important results are set forth belon.

a. The Staining Nethod of Nis8l..- Nissl's description of his method ('94) called for the fixation of the tissues with alcohol. Ihis bas proven an unsutisfactory fart of the technique for my work. Better cytolopical preservation ty tar has 
been secured throukh the use of the chrome-oxalic mixture of Graf ('99). This reagent akpears to have escaped the Eeneral attention of microscopists, at least no mention is made of it in the fifth exition of Lee (1900). The composition is here Éiven:

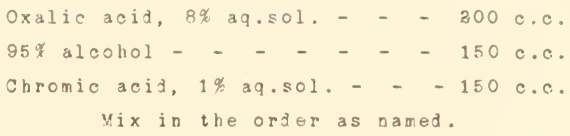

Quite small pieces of the brain were fixed in this fluid for six hours, and the fixing agent $w a s$ then washed out with 70\% alcohol. Sections were đade ky the paraffin method.

The slide was taken from distilled water, and the steaminehot stain of $\mathrm{Niss}$ r $\mathrm{k}$ as poured over the sections, five ninutes. The excess stain was rinsed away with distilled water for the briefest possible time, and the water clinging to the slide was atsorbed with filter paper. Differentiation with the anilinalcohol of Nissl took but a fen seconds, being stopped by flloodin nith oil of cajeput just as soon as the sections took on a delicate rose tint. Clearine with the oil of cajeput was aijed by holding the slije for a f'ew monents in sentle heat. Mountin sas done in colophonium dissolved is xylol. The stainin is remarkatly precise, and the color has shown no tendency to fiade.

The counter-staining methods described by Held ('9.5), and by Tarrington ('a3), were also afplied, with certsin modifications found necessary. The erythrosin nixture of Held 

was Eently warmed, poured over the slide for ten seconds, and then nashed away quite thoroufhly with distilled nater. Styinins was 3one with either the pure stain of Nissl, or with the same diluted with an equal volume of $5 \%$ acetone; the results did not seem to Jiffer very much. In either case, the stain was heatej and allowed to act for five mirutes. Difierentiation with 0.19 alum solution for just a few seconds, until the sections appeared distinctly red, was followed by a brief rinsing witr water. The results given ky this process have been of value as an accessory to the pure methylen-blue stain, but they are far from supplanting the original method.

b. Intra-Vitur Injecticn.-- The colorstion of the nervecells through intra-vitun. injection of methylen-blue was given a most thorough trial, a laroge number of animals being utiljzed for this purpose. The subcutaneous injection preferred by Neyer ('ge) is not practicable for Nustelus because of the absence of either loose areolar tissue or of lymph spaces. The syringe was ther.efore inserted directly into the vascular systen. A ñ solution of methylen-blue, EX trand, nas injected some four times durirg the course of an hour. Beginning 3 small quantity, the amount rose successively until as much as 30 c.c. $x$ as introduced in the fingl injection, making some 50 c.c. in all. This whole process nss छoverned, however, not by fixed quantities of the reagent nor by exact periods of time, but by the stopuine of the hasrt's action and the blue- 

ness of the animal. Half an hour after the firal injection, the brain was removed, cut into thin slices, and then exposed to the air until the tint has become a brighter blue. In the conversion of the unstable methylen-blue stain of the fresh tissues into the insolutle form. I have not been successful with the methos recommended by Eethe ('ga). The use of the picrate of ammonia as a prelininary fixer has seemed to actually impair the clearness of the final preparation. I obtaired the best results with the solution Eiven by Meyer ('gs):

Distilled water - - - - $-100 \mathrm{c} . \mathrm{C}$.
Ammonium nolybate - $-10 \mathrm{grams}$
Hydrochloric acid - - - -10 drops

Heat the first two ingredients togetber, then add tbe acid.

The pieces of brain were placed in this mixture, cooled witb ice, for four hours. They were then washed with iced water for two hours. Dehydration with cooled alcohols, and imbedding in paraffin were hastered as much as practicalle; in fact, it is nell to have the tissues in parafiin on the same day when the injection was begun. The preparations were used chiefly for the study of the architectural relations between the neurones, and so tbe sections were cut quite thick.

The results given by this method are characterized by exceptior.al clearness, due, in large measure, to the selective coloration of certain neurones, only. The atteinment of the desired end is far from constynt, however. Atter experience haj shown the rule, care was always tgken to apply this technique only to those animals which had teen in an active conji- 

tion, fresh from the open sea, if possible. But even with this precautionary recosnition of physiolosical conditions, so far as they could be readily determined, there apparently yet remained some unknown factor which caused a negative result in some instance where it was least expected.

\section{Iron Haematoxylin.}

This reagent was imagined by Heidenhain ('g2) for refined cytological rork, but it truly has a place in neurological investisation. It is a most excellent stain for defining the internal structure of the nerve-cell, and also for the tracing of nerve-fitres. For the latter purpose, iron haematoxylin has proven itself preferable in this research to the stain of Neigert, since it defines the axis-cylinder instead of the myelin, permitting fibres to be followed through their ramifications entirely to the terminal arborizations.

Fixation of the tissue may be done with any good fluid. Where the tracing of axones, only, is desired, 10\% formaldebyde cannot be surpassed; but where the aim is purely cytological, either the chrome-oxalic mixture of Grat or the filuid of F'lemmin will Eive superior results. For work on axis-cylinders, celloidir sections were made 37 micra thick; and for the minute study of the nerve-cell, thin sections were cut ky the parglitin method.

The sections were brought from distilled water into the 

mordant of $4 q$ iron alum for two hours. The excess mordant was then rinsed axay with distilled water. Stuining with $0.5 \%$ aqueous haematoxylin required at least four hours tor entirely Satisfactory definition. Clean tap-water was used for washing out the uncombined stain, since this appears to fix the lake more firmly. The styin was differentiated with a $2 q$ solution of iron alum, frequently renewed. This process was observed with the microscope, and when the desired effect had teen obtained, the sections were transferred to tap-rater. Thoroukh washing at this stase is necessary to prevent fading of the stuin, anj the slight alkalinity of ordinary tup-xater appears to be a factor aijin@ in its preservation.

\section{The chloride of Vanadiun Kethod.}

The technique required for staining with the chloride of vanadium method of Nolters ('90) is somewhat trouklesome, but the results, when obtained, certainly justify the means. Nervecells, axis-cylinders, ependyas, and neuroglia are all defined in one and the same section. No other method known to me Eives so comprehensive a picture for Eeneral study. Its sole value lies, bowever, in the purely general scope of the results.

It is hardly necessary to give a description of the process here, since its essentials are outlined in Lee (1700, p.410). 

SECTION IV.

THE OBLONGATA.

\section{General Morbhology of the Oblongata.}

In Nustelus, the transition of the architecture of the spinal corj into that of the oblongata is traceable with 3 degree of definiteness which rarely obtains in other animsls. It is therefor.? possible to contribute towara the solution of certain problems which vex the stujy of this highly specialjzed region of the mammaljan brain. Only an introductory survey of the entire field will be presented here, leaviug the development of details and the consijeration of special questions to the following subsections.

As the canalis centralis xidens into the fourth ventricle, the several structures of the cord lateral to it are pushed into more and more widely divergent positions, retaining, however, essentially the same mutual relations to each other. Concomitsnt with this diverefence, the dorsel ependy na becomes broadened to forn the morpholopical roof of the fourth ventricle(Fig.?,t.c.p.).

In approaching the oblongaty, the ventryl cornus are encroached upon more ana more by commissuryl fitres until, just 

above the level of the first spinal nerve, the mammalian hypoछlossus, these nuclei disappear altogether as contiuuous collections of nerve-cells. A small number remain associated as the nucleus of the sbducens, while the remgining neurones become scattered through the formatio reticularis (Fip.?,c.n. and t.n.)

The intermediate zone and the dorsal cornu of the cord are relatively small in size, but as the paired halves diverfe to right and left of the fourth ventricle they increase in mass and assume characters and tunctions of a special order for each refion. The intermediate Eray matter contributes the lobus vaki and the viscero-motor nucleus of the oblonéata; while the dorsal cornu becomes specialized as the eneral cutaneous nucleus. We will note each of these in turn.

The lobus vasi is a longitudiral elevation in the lateral xall of the fourth ventricle (Fig.1,1.vE.). Anatowically, it is one of the most striking fegtures of the oblongata because of the row of beaj-like prominences into which its surface is thrown. The position of the structure as seen in a transverse section is represented in Fig.?, l.ve. The lotus vasi is the terainal station for communis components of the VII, IX, and $X$ nerves; see Sulsection 4. Certuin of these fibres, instead of passire directly to their termination here, enter a compact bundle and run posteriorly to the spinal cord. This tract is known as the fasciculus communis. Its position in the oblonestg will be seen in Fis.?, f.c. 

The viscero-motor nucleus is a column of larpe nerve -cells imbedded in the lateral wall of the fourth ventricle (Fif.? v.m.n.). Different fortions of this column are known as the nucleus ambiguus, and the motor nuclei of the VII and $V$, respectively. The axones for the motor roots of the V, VII, $I X$, and $X$ nerves take their origin from these nerve-cells. It is a curious fact, however, that but tew of the axones pass diractly into their nerve-roots, but take a course first in the fasciculus lonofitudinalis dorsalis. This is a massive, paired tract, the two bunales lying side by side beneath the filoor of the fourth ventricle (Eig.?,f.l.d.). There are present in the dorsal lon@itudiral bunale nerve-fibres from several sources. Into this crowded hishwsy the axones from the viscero-motor nucleus penetrate, to finally emeree as the motor roots of their respective nerves.

The dorsal cornu of the cord is continued irto the oblonEata ir sn enlarged condition, and it becomes associated with sensory fibres of the $V$, IX, and $X$ nerves to forn the Eeneral cutaneous nucleus (Fig.?, f.c.n.). The neurones of this nucleus provide a primary termination tor certain Eeneral cutaneous fibres; while others turn backward to the corjas the spinal V tract. At the posterior levels of the obloneata this system appears dorsal to all other structural features, the pair fornin the rounded, crest-like margins to the fourth ventricle. Proceeding anteriorly, the nucleus is pushed into a position both more ventral and nore lateral by the sucerposition of a 

new structure, the tuterculun acusticum.

The tuberculum acusticum is shown in Fiss. 1 and ?, t.a. It extends posteriorly from the restiformis along the lateral margin of the fourth ventricle some three guarters of the distance to the calamus scriptorius, tapering as it proceeds. It is separsted from the general cutaneous nucleus below it by \& fissure which reches well towara the limitans interna. The suter zone of the acusticum is structurally continuous witr the cerebellum; it is known as the cerebellar crest (Eif.?, cb.cr.). The acusticum is the centre for the nerves of the lateral line sense-organs and the internal ear. Its interpretytion will be considered in Subsection 7 .

\section{Feviey of Nerue Somponents.}

A proper point of vien for the structure of the oblongata can best te obtained through familiarity with the problems of the cranial nerves pertaining to this refion of the brain. Reference to the text-books of descriptive anatomy will discover hardly $a$ trace of the conceptions which domingte the modern morpholosy of nerves. The discovery made by Sir Charles Bell as to the character of the dorsal and ventral roots of the spingl nerves was one which represented 2 distinct advance in sound physiology, tut the afflication of Rell's fornula to the crarial nerves has not teen projuctive of sound morptiolofy. The effort to compare the crarisl with the spinal nerves on the 
simple basis of "sensory" and "motor" could not avoid leading to many dopmatic positions concerning the r.eal character and ultimate aistribution of many fibres. An attempt to solve such intricate problems tbrough so mechanical a method could hardly be otberwise than frulty, particularly when applied to the specialized conditions of the mammalian nerves. A thorough stuay of the less modified cranial nerves of the Ichthyopsida is a necessary preparation for sound morpholosical work in the hisher field.

The views or cranial nerves held by the neurologists of to day were founded less than a decade since, but the germ of the central idea is tracearle to a somewhat earlier date. Gaskell in a series of publications ('85,' 83, ' 89 ) was makinf the attempt to solve the metamerism of the head and the orisin of the vertekrate nervous systen through a study of the nerves. He took occasion to show that a spiral nerve not only embraces the sensory and motor fibres of Bell, but that its structure, distribution, and function, as well as the arrangement of its central nuclei, lead to the divisibiljty of the nerve into two parts. One part is somatic, innervating the external surfuce of the body, and the auscles derived from the muscle-plates. The other division is sulanchnic, supplying the internal orsans and surfaces, and those wuscles which Gaskell characterizes as "Jerived from the lateral flates of the mesoblast". Gaskell attempted to show, further, that the cranial nerves arise frow 
centres homologous with the spinal centres, likewise divisitle into somatic and splanchnic eroups.

The impetus given by Gaskell has led, ultinately, to the modern conception that a spinal nerve embraces neurones derived from four distinct sources, with as many different distributions. There are, then, to be distinfuished ir a spiual nerve: (a) Somatic motor fibres. These neurones have their cellbodies situated in the ventral cornu of the cord, their axones emerçe throush the ventral root, and they are distributed to the body musculature. (b) Somatic sensorv neurones, the cellbodies of which comprise the dorsal Englion, snd their fibres connect peripheral enj-oresns with the dorsal cornu of the cord throuph the medium of the dorsel root. These two divisions of a spinal nerve comprise the principal number of fibres in the two roots. (c) Viscero-motor; these fibres take their origin from a Eroup of cells, the paracentral nucleus of Inuf and Collins ( 93 ), lying lateral to the canalis centralis; they emerese throush both the ventral and the dorsal roots, and are distributed to the non-striated muscles of the viscera. (i) Viscero-sensorv neurones, from the viscera, throush the dorsal root, to ternination in the internediate zone of the Eray matter.

A new era ir the investifation of cranial nerves was inauEurated by Strong ('95) when he made the application of these princiules to larval amphibians. Strone round that it is practicable to reconnize certain distinct classes of fibres or 

components of the cranizl nerves, which are to be distirpuished from each other by their size and histolofical characters, by their central oriein or connections, and ty their ultinste distribution. Kingsbury ('97) mede a carefiul extension of these findinfs to several Eanoids and teleosts; while Herrjck ('97, '39, '99) has traced the conditions in the bony fish Venidia with adairable clearness. Certain conclusions reached by Johnston ('98b) from his study of the ganoid brain stand apart from the Eeneral trend of recent work, and to these we shall return furtber on.

The principles developed by the researches of Strong, Kingsbury, and Herrick, nay now be applied to the cranial nerves of Mustelus. There are to ke distinguished five systems of nerve components:

a. The Somatic yotor sustem.-- This system of neurones is homologous with the ventral-cornu neurones of the spinal cord. The fiures take origin from cells having a ventral location in the brain, and they innervate striated somatic muscles. The only representatives of this class are the nerves of the eye-miuscles, the III, IV, and VI, respectively.

b. The General sutaneous system is so callej because concerned with the innervetion of the skin of the head, but it is not associsted with specislizej peripheral sense-orsans of any kinj. Its fibres are components of the $V, I X$, and $X$ nerves, and they are homolokous with the somatic sensory suiral fitres. The cell-bodies of these neurones lie in sensory Eanklis, and 

the contral termination is comparatse to that of the somatsc sensory spjusl fijbres. Part of the gericral cutymeous fibres terminate in the Eener.yl cutaneous nucleus, the lomolofue in the heaj of the jorsy] cornu; see: Subsection f; but other.s turn into tre spinal V tract and tyke a course posteriorly for ultiniste terminction in the dorsal cornu of the cord. There can be no question as to the identity of this system with the somatic sensory systen in its simpler conditjon.

c. The Viscepo-Notor Syetem.-- Fibres of this system form the motor roots of the V, VII, IX, and X nerves. The cellrodjes from which the axones srise form s column of cells lateral to the fourth ventricle, known, accordins to the level, as the nucleus ambiçus, and the notor nuclei of the VII and $V$, respectively. This column of cells is the cranial continustion of the paracentrul nucleus of the corr, and the honolory is renderej complete by the aistribution of the fijbres to the visceryl muscul эture.

d. The communis system... This term is used in the sense Jefined ty Herrick (' $99, \mathrm{f}$. ? 9 ), and as the equivalent of the fasciculus communis of Strong ('95) as applied to the system in the tadpole, and of Kingstury ('or) as used for various fishes. Commois fitres are components of the VIJ, IX, and $\mathrm{X}$ nerves. They are whollv sensory. They inmervate visceral and mucous surftuc $\div s$, and also $l \neq s t e-t u d s$ and those specinlized sense-orfans of treskin (enj-tajs) not relormle to the latersl line syster. The titros s re charucterized ty their sagll 

size, and they are distukuishatle from other componts of the same nerves by this leature. They terminate ju the lotus vafi. The greater number of them in Nustelus pas directly to their cientrul termination without enterine the fasciculus commun, usine this term in the sense as originelly gpplied ky Ostorn ('83) to a definite lon@itudinal tract.

The comunis system is bomologous with the viscero-motor system, the lobus vagi in which central termingtior occurs being the continuation into the brain of the lateral or intermediate zone of Eray watter in the cord. The viscero-sensory system in its original condition is, however, of far less imfortance than its cranial representative. The comunis systen not only innervates visceral oreans, but it has come into relations with taste-tuls in peripheral erä-tuas, as well. It therefore is a system havine a very considerable mạnitude.

$e$. The Acustico-Lateral system is concerned exclusively with the innervatior of the internal ear and the organs of the lateral line. Its fitres are components of the VIl, VIIJ, and $X$ nerves. Ihey penetrate the tuberculum acusticum for imnediate termination there, or for a course farther for war into the cerebellum. The significance of the latter termination will he discussed later. The components of this systen. in the VII and $X$ are to be readily distinguished from other fibres associstej with them by virtus of their frest dimeter. The acustico-lateral system is rot refresented in the spinal nerves, as the tour precedins cranisl systems are. The 

evolution of this system is bound up with that of the peculiar series of sense-organs whict it supplies. Until the evidence is more nearly complete as to the entryology anj affiuities of the laterul line and its nerves as a whole, we really are not xarranted in making any positive assertion as to its phylofeny. Sone evidence as to the possible origiu of its centre will re given in Subsection 7 .

\section{Neurones of the Ventral cornu.}

Jpon reaching the level of the otionfata, the ventral cornua of the corda tecome broken up as distinct collections of nervous matter. Somatic motor neurones tirom this source are Erouped into the nucleus for the VI nerve, but elsewhere there are only isolated indivijuyls lying between the fibres of the formatio reticularjs. In an earlier paper touching this subject ('gro), I left the interpretation of these scattered neurones undecided. It is non certain that they correspond to the comissural cells and the tract-cells (vorderstrangzellen), respectively, which vonLenhossek ('g4) has jescribej from the spinal cort of the selachiur.

a. Tract-Reurcres.-- The ventral tract-neurones aro sciattered over the mid-ventral rield of the otlongats on each side of the raphe ventral to the dorsal Jonfitudinal lunjles (Hif.e, t.n.). They are to te readily distineuisled from all other 

neurones of this region by thej r size, for they are reslly Eiants. Their size is exceeded only ty the neurones of the midbrajn roof-nucleus described in Sectior VI, Subsection 2.

As to external form, the tract-neurones have a wije ranfe; a representative individual is drawn in Fig.?, t.n. There sre from three to five dendrites, and their disposition controls the shape of the cell-body to a very high degree. The dendrites may te given off at ofposite extremities of the cell, in which case the outline of the cell-body is a ruch elongrted one. The form is rounled or stellate when the dendrites are spaced at equal intervals. A dendrite is always a massive process, very wide at its base, tapering quite gradually, and reaching fer out into the surrounding nervous matter. It gives origin to but few branches.

The axone alnays arises from the body of the cell. It runs for 9 short distance in the transverse plane and then turns into a longitudinal kundle of fibres on the same side of the oblongats, or even on the spposite side.

The internal organization of a tract neurone is shown in Fig. 44. The cytoplasa is voluminous in quantity, investirg the nucleus witt a thick layer on every side. The outline of the nucleus is reqular, and in form nay be circular or oval. There are 31 nays a remarkatly suill number of coarse chromatin Eranules, the chromatic aaterial beinf distributed in the form of a delicate retjculua. Subsidirry nucleolj are rarely present. 
The cytoplasm is, as already noted, Ereat as to actual quantity. Some neurones when staired by the method of Niss absorb the methylen-blue equally throuchout all parts of the cytoplasm, and hence they appear almost homogeneous; the sifnificance of this tact is notej kelo'. Other neurones in the same section exhilijt a large quantity of tigroja substance; the neurone representej in FiE. 44 is of this type. In the vicinity of the nucleus the tigrojd-bodies are ususlly triansular in outline, and some of them rave a very considaratle size. Tieroijs are found far out in the denarites, assumiré here 3 lenticular or even a linear form, their lonf axes parallel Nith the course of the denjrite. A fiuely Eranular axonebillock lies at tbe origin of the exone. In rectangular cells, as the one fifured, the hillock may be spresa so widely as to assume a disk-like form. The tigroids tend to become somewhat saaller in the region of the hillock.

The tract-neurones are not demonstrated resilly with either chrone-silver inpregnation or the intra-vitun injection of methylen-blue. The homopeneous coloration assumed ty some of then with Nissl stainin£ has 31 ready been recorded. The character of such micro-chenicis reactions inaicates clearly that many of these neurones are not physiolosically active, at least not all of the time. The axones frou some of then may enter. the motor root of one of the anterior sfinal nerves, anj, beinf in an active conjitior, cive indications of it in a well-agrkej store of tiErojs substance. Sther neurones, however, chairing 

together hisher anz loner levels of the ot lorfaty, have come to have their functiors larkely usurved ty the develorment of more specialized tracts. Such neurones are, therefore, defraded to a far lower plane of metatolic activity, and they respond but feebly to those of our stains which depend upon the presence of jefinite chemical constituents of the protoplasm.

b. Commissural Neurones.-- The commissural neurones are readily distinguishatle from the tract-ricurones by their sualler size (Eig.r,c.n.). Comissural neurones have a wide aistribution. They are scatterej between the tract-neurones in the viciuity of the rejian raphe, and they also are to be found in all parts of the lateral region as far jorsil as the base of the general cutaneous nucleus.

The external morphology of a commissural neurone is represented in Fif.?,c.n. The cell-body is relatively small in proportion to the extension of the denjrites and the axone. The form of the cell is usually an elongated oval or an irragular triangle. The denarites are quite often only two in number, arising from the ends of the cell. The course taken by the dendrites does not seem to be affected in the least by the tracts of filies of the formatio reticularis, since it frequently takes thea obliquely tbrough a bundle of arcuate fitres. The denarites are stout at their bases. They Eive of only a few short tranches. The principel axis of the dendrite pursues a rather even course for a conparytively lone distance, 

tapering Eradually to the end. Its surfice tears tut fen Eemmules.

The axone may arise from the body of the cell, or, when the long axis of the cell is horizontal, from one of the dendrites. It takes a course directly for the opposite side of the oblongats, giving off collaterals near its point of origjn and then remining free from them. The function of such an axone is, joubtless, commissur.al.

The internal structure of a comissural neurone from the right side of the oblongata is arawn in Eig.45. The cytoplasu is always far less voluninous in proportion to the size of the nucleus than in the tract-neurones. The nucleus is almost invariatly oval in outline, with its major axis disposed the long ray of the cell. The nucleolus is not consuicuous. The chromatic material is distributed in elongated, irregularly forned strands which lie throughout all parts of the nucleus. The several masses may be connected with each other, but only the faintest sugpestior of it is indicsted witr the righest \əEnification.

The cytoflasm contains a consideratle quantity of tiproid substance. A few broadly trjancular ticroids are scattered rourd the nucleus, sometimes in the condition of nuclear cars. The Ereater part of the tisrois substance is to te found at the xide expanse where the cell-kojy nerdes into a jendrite. Here the form of tifroid is a crestly elonpsted triunfle. This is replaced farther slon the jendrite ty syindle-shaped or 

linear masses. A suall axone-hillock of fillely Elanular matter. ljes just witlin the orisin of the axone. The tisrojd-bodies near it are saaller and more irregular than elsewhere.

The commissural neurones, in contrast with the tractneurones, alkays respond to the stains applied; this indicates a uniformly active physiological condition. Comaissural neurones douttless have 9 not unimportant place in the economy of this resion of the brain, into which so many iapulses sweep through afferent nerve-fikres to great vital centres. The chaining together of the opposite halves is precisely mat we should expect to find under such conditions, and the mechanism is provided by the comujssur.9l neurones just described.

\section{Lobus Vagi and Fasciculus gommunis.}

The lobus vagi is the terminal station for the communis titires, conponents of the VII, IX, and $X$ nerves. Its Eeneral morphology has been outlined in Subsection 1.

The structure of the lobus vagi enbraces a narrox zone next to the limitans interns occupiej chiefly by nerve-fibres; and a deeper part in which there are both neurones and terminating fitres. The course of the nerve-fitres will be considcred later.

a. Neurores of the Lobur Vagi..- The constituent neurones of the lobus $v a E i$ are jany in nutiber anj closely crowded. They 

are comparatively suall in size, and are referatle to type I] of Golgi. The external norphology of a neurorie is shown in Eis. 4 .

The shape of the cell-body ranges frow almost triancular. to troadly oval. The axone may emerge directly frou the cellbody, or it may spring from one of the larper dendrjtes. It fursues an irrẹular course away from the limitans interna into the deeper levels of nervous matter. Before proceeding far, it breaks up into a widely-spread arborization such as is characteristic for neurones of this type. I believe from the course of the axones that they constitute a means for transmittin£ impressions to the viscero-motor nucleus; see Sutsection 5.

The denarites are tbree or four in number. They are guite stout near their orisin, they taper @radually, and they do not kecome very fine at their terminations. Iheir morpholosy is simple, since there are only one or two tranchings at most. Their lengths may be as great as that of the axone, and so the denàrites from all of the neurones here interlace to form 2 veritatle jungle. The surface of a dendrite bears $\approx$ few gemaules, together $x$ ith certain small knobs and elevations of various shapes.

The internal organization of $g$ neurone from the r.ift lotus vagi is shoxn in Fig. $4^{\circ}$. The nucleus is alkays larke in proportion to the bulk of the cell. In some instunces there is only a thin film of cytoplasu enclosing it at certain points. 

The nucleus is a more or less perfect oval, holjinf one or more nucleoli. The chromatin is distributed in a few thin, branching strands which Eive the apperance of joining in some parts of the nucleus. The chromatic never stains intensely in these neurones, and so the nucleus is represented by liert coloration in the figure.

The cytoplasm lies principally in the broad areas where the cell-body merges into the dendrites. Its tieroid substance is never collectej into larce masses. In the region of the nucleus, the tigrojd material is chiefly in the condition of mediun-sized granules, with a few small triangles intercalateo. The denarites have fusiform or linear ti froids scattered at irregular intervals. A very suझll Exone-hillock @ives origin to the axone. In the specimen fisured, this lies at the side of the most massive denarite, but this location is not the rule for these neurones.

b. Termination of communis Fibres.-- Ey far the greater number of the communis fijbres from the VII, IX, and X nerves uass jirectly to their termination in the lobus vagi, a few, only, entering the fasciculus commis, descrited below.

Fibres penetrate tbe lotus vaci for ultinate terningtion chiefly from the jorsyl side (Fif.?,c.t.). They reach this cosition by 3 sweeping curve which carries them to an ever hickler level as they run irward from the exterior. These incoming fitres constitute a thill stratum next the limitans inter- 

na, the neurones lyinf just beneath. The fillal artorization occurs near the body of some neurone. It is of a narrowly tranching type, with fine, bristle-like twigs terminstiuf the branches (Fis.4,c.f.).

c. The Fasciculus commis.-- This remarkatle tract was Eiven the name it now bears by Ostorn ('ss) in recosnition of the comaon relationship of several cranial nerves to it. Vsrious authors haj notjced the ïasciculus communis frevious to tbis time, but they hà failed to Érasp its sienificance. Stieİ ('73a, p. 439 ) had noted the presence of such a bundle in the spinal cord of the selachian; while Eohon ('r, p, p.4^) Jescribed it from the selachian train unjer the nane fasciculus longi iudinalis latepalis. The latter writer conjectured that it aight pertain to the tegmental system.

In liustelus, the fasciculus communis is a very sharply defined tract extending posteriorly from the VII nerve into the spinal cor.3, where it lies close besije the oray watter dorso-lateral to the canalis centrilis. Its position ill tha oklongata is shown in Fig.?, 1.c. During a part of its course, the visceromotor nucleus is triversed by it. Some of the communis fibres, instead of pursuine a course to tbe lobus va@i for termination there, turn jownard into the fasciculus communis. Thence they are carried posteriorly into the spinal cord for their ultiate distribution.

From the account Eiven by Strong. ('95) of the fisciculus 

communis in amphibians; and by Herrick ('99) for the tony fish, J conclude that this tract is developed in Nustelus to a conspicuously less defree. The significance of this smaller size for the brain of the selachian is not clear. The communis t'ibres are essentially viscero-sensory, but there have been annexed to the system certuin external sense-organs, such as tyste-buas and end-buas. There are no observations indicatinf markeà differences between the visceral connections of this system in Nustelus as compared witr teleosts and amphibians. In fiact, the archaic value and deep-seated physiolosical importance of such connections in all vertebrates nould lead us to infer a considerable sinilarity in relatej £roups. Te thus appear to be thrown dpon the jore recent yajitions to the system for the explanation. It seems to me that a comparative investigation of end-buds and taste-buds will contribute much toward the solution of questions pertyining to their central tracts.

\section{The Viscero-notor fucleus.}

The aboption in this paper of the name viscero-motor nucleus expresses the need for a Eeneral term which shall include all menbers of the morpholopjcally continuous colun of cells @iving origin to the motor fijures of the $V, V I 1, I X$, an $X$ nerves. This nucleus is the continuation into the oblongaty of the paracentral nucleus of Onuf and Collins ('ga), and the 
components haviug their origin bere innervate viscera.

The nucleus is composed of quite large neurones. The only larger ones in the oblonfaty are the figantic tract-neurones described in Subsection 2,3 . The cells are arraneed in a compact cluster, as seen in transverse section, and this is traversed durirg a part of its course by the fasciculus communis. Eig.?, v.m.n., illustrytes the disposition of the neurones and their characteristic forrns.

The cell-body has its form influenced ty the number of its denarites, ranging from triargular to stellate. The denarites are alnays several in number. They are massive processes, often arising trrough such wize bases that it is diffjcult to say where the line of derarcation between dendrite and cell-body should be arawn. The jendrites branch freely, and the closeness with which the neurones are arranged छives, therefore, a most complicated tan

The internal or ganization of a viscero-motor neurone is represented in Fis. 47. The nucleus is central, or only slifntIy eccentric, anj it bas an evenly rolinjed contour. The nucleolus is larpe; there is rarely y sutsidiary rucleolus. The nuclear reticulum has a coarse mesh which exhibits Erest clots or lumps of chromstin at the points of intersection.

The cytoplasm contuins tifrojd-todies of various sizes. The larpest wasses lie in the field of the nucleus. The ones next to the nuclear membrane nay assume the for of nuclesr caps. At the periprery of the cell, the prevailinf form of 

ti groid is much elongated. It lies parallel with the marsin of the cell. Tieroid masses are continued far along the dendrites, even into the tertiary tranches. They are disposed farallel *ith the course of the dendrites.

In that side of the cell from which the axone arises, the tigroids have a special arrangement. The axone-hillock (Fis.47,ax.h.) is an oval mass of finely Eranular material, and the tigroid-boßies are packed rather densely round it. The form of tigroid is also less elongated here, merely an irreg̨ular lump.

The axone arises directly from the body of the cell. While it is destined to ultinately be a component of either the $V$, VIl, IX, or X nerves, it @enerally takes quite an indirect course. The usual way is through the mediun of the fasciculus longitudinalis Jorsalis. An axone passes into this kundle to finally emerge at some other level. In Fig.47, the axone passes dorsal to the fasciculus communis. There is a bunde of fibres of considerable size lying here, composed chiefly of axones which have emerted from the dor.sel longitudinal bundle to enter the nerve-root. Other axones, but these are lew in number, way enter the nerve directly. Still others pass into a bundle of arcuate fibres and douttless enter the nerve on the opposite sije. These severgl paths to the nerves are shown in Fig.?, v.m.f.

The viscero-motor neurones have an internal structure which is conspicuously motor in character, the larpe amount 
, 
of tigroid substance representing wuch expenditure of ener Ey here. The larpe size of the neurone is evidently the correlative of the importance which the system assumes in the innervation of Ereat vityl orpans. Such innervation requires a nexus with viscero-sensory neurones, and the means have already been susgestej in the preceding sutsection, the interlacing of the axones from the lobus vagi with the dendrites of the viscero-motor nucleus. This @ives a complete reflex circuit for visceral innervation.

6. General cutaneous bucleus and Soinal V Tract.

The literature of tue portion of the oblongaty included here is in some confusion. The older writers did not have methods of investigation which would demorstrate the presence in this region of several important groups of neurones. They did see that it contsins numerous bundles of nerve-fikres, however, some of shich run to the cerebellum, and so pedunculus cerebel $i$ appeared to be a perfectly satisfactory designation. Kingstury )' 97 ) extended the term spinal $\nabla$ th tract to both the nuclei of the region and the trigeminal fibre-tract proper; such use of a term orifinally intended to desifnate a definite Erouk of nerve-fibres is certyinly to be avoided as leadine to confusion. Johnston ('98k) appears to irclude 2 part of this refion under his tuterculum acustlcum. Since there appears to be need for s precise ter. which shall desis- 
nate the several nuclei of the Eeneral cutyneous system, I therefore propose that the whole be called the general cutarieous nucleus.

The seneral cutaneous nucleus is the contiruation into the oblongaty of the jorsel cornu of the spinal cord, and it carries its associated tracts nith it. Its position will be seen from Eig.?, E.c.n. In structure, it is indeed complex, embracing as it does, three grours of neurones, larpe numbers of nerve-fitres intercrossine in several directions, the spinal $V$ tract, and many supporting elements. The intrinsic neurones will be considered first.

a. The Molecular Layer.-- The nolecular layer acpears in a trarsverse section as a jorssl cap to the otber constituents of the nucleus (Fig.?, x.1.). It is seen to be continuous with the cerebellar crest of the tuterculum acusticum.

The neurones of the molecular layer are of two varieties, the molecular neurones and the neurones of Purkirje. Both of these varieties are identical with those described in Sutsection 7 for the tuterculur scusticun; their morphology will therefore not be Ėiven here.

As to distritution, the minute molecular neurones are found scatteres through the whole thickness of the molecular layer. The Furkinje neurones, on the contrary, lie only in the deeper part of the layer, sendinf their freat dendrites irto the upper levels. The possitile phylofenetic sienificance of the presence of the molecular layer in this part of the 

brain will be treated in the theoreticyl considerations of Subsection 7 .

b. The Substontia Gelatinosa.-- The Eelgtinous substance of Eolanjo is continued from the spinal cord into the oblonfaty. It takes on such an intinate relation to the terninating nerve-fibres here that Barker ('99) has proposed to call it the nuclei tractus soinalis nervi trigemini. The Folandic sutstance occupies a position hish up in tbe dorsal part of the gener.al cutaneous nucleus, just beneath the caf of the molecular layer, and itselt forming an investment for the bundles of fibres and larper neurones of the central miss. The complexity of its structure, anj the difficulty of stainirg it with the usual reagents are facts well known to microscopists. The nerve-cells of Rolando's sutstance in the spinal cor.j have keen studied by vonLenhossek ('94) from man, the pie, and the mouse; while Ramon y Cajal ('ge) has Eiven us an elabor.ate jescription of the oblongata of the mouse. It gives me great plessure to be able to extend our conceftions of this peculjar formation to the field of the train of selachisns.

In Mustelus, the structure of the sutstantia gelatinosu foreshadows to a remarkatle degree the or ganization which has been descrited for the hicher vertebrates. The neurones sre associated in groups; a refresentative collection is jrawn ir Fif.5. The axones and dendrites tranch profusely and interlace so closely that the simulacrum of a fite netrork is Eiven. In 

this tangle, certain nerve-fibres of the ceneral cutaneous system terminate. Such a fibre is shown in Fif.5.p.c.f.; its arborization may be distinfuished from the tangle of neurones in which it lies by the somewhat Ereater size of its terminal twi

The neurones of the sutstantia gelatinosa, considered morpholosically, are of three varieties, all of which are represented in Fis.5. The one that is present in Ereatest numters, @iving character to the formation as such, is of quite minute size, and is an extreme example of Golęi's second type (Eig.5,3. The cell-body is very small, poly छonal in form, and there are a fex short denàrites. The axone ramifies immediately into an extremely complex series of tranches, constituting the principal renber of the tangle mentioned in the preceding paragraph. These axones are strikingly conspicuous structures when successfully impregnated with chrome-silver.

A second form of neurone is considerably larger in size. its dendrites enter into the tangle referred to, instead of its axone. From a poly छonal cell-body, some three or tour denarites radiate indifferently in all directions. The dendrite is of ine calibre, and it branches reveatedly into ever finer twies. The branchine of this system is far less profuse, however, than that of the axone of the first variety described. The difference will be readily seen by reference to Fik.5,b. The axone takes a course out of the gelatinous substance into the deeper parts of the nucleus. It Eives of $f^{2}$ number of 

lonp collaterals during that part of its course lyirp in the surstantia gelatinosa.

The two kinds of neurones just descrited evidently constitute the physical tasis for the central reception of Eeneral cutaneous impressions. The first variety, with its short axone, is so concerned entirely, it would seem; while the second one jescribed, having its axone proceeding to deeper reEions, is probarly involved to an equal degree in botb the reception of impressions and in their distribution to deeper levels.

Still a thira type of neurone remains to te described (EiÉ.5,c.). From an oval cell-body, a fen sparsely branching dendrites arise which lead far out into the surrounding field. The axone takes a course into the deeper nervous matter, \&iving off only a few collaterals. This form of neurone is found outside the margins of the groups, and apparently is purely associative in function.

c. The Deever Neurones.-- The deeper parts of the Eeneral cutaneous nucleus are occupied by fitres having courses in several different directions, and by the tundles of the spinal $V$ tract. Neurones are scattered at intervals between the nervefibres, with a somewhat more closely crowjej area just dorsal to the lobus vaEi. Neuroflia is especislly abundant in 911 parts of the nucleus, proviaing a support tor the intricate पा?ze of nervous structures. 
The external morpholosy of a neurone from the middle region of the nucleus is shown in Fis. $f$. Such a neurone is consideratly larper in size than any neurone from the sutstantia Élatinosa. From an elonǵated-oval or trianpular cell-body, three or four dendrites proceed straight outward into the tangle of nerve-fihres and neuroglia. A dendrite is a rather stout process. It has but fen branches, and these are of small size. Its surfice bears scattering gemmules and minute knobs. The axone tykes its origin directly frou the cell-body. It runs in a medio-ventral direction.

Two neurones stained with metbylen-tlue are represented in Fig.48. These are from the median collection just dorsal to the lotus vasi. The nucleus of such a neurone is proportionately quite large. It is also eccentric in its position, consequently cells are of ten found in which the nucleus appears to be in direct contact with the cytoplasmic pellicula at some point. The nucleoli are of some prominence. The chromatic material is also conspicuous. It is distributed in branching strands of some thickness in places, and the several strands may have slicht connections.

The cytoplasm is often practically absent at the side of the nucleus. The denirites are so thick, relatively, at their bases that the Ereater part of the cytoulasm appears collected in them. The tigroid sutstance is most abundant in the vicinity of the nucleus. The irdividual uasses here gre usually irreçular in form and quite small in size. In the basal farts 

of the dendrites, the tiproid-bodies become elongrted. These do not reach f'ar alons the dendrites, however.

d. Termination of General Cutaneous ibres.-- The nervefibres of the Eeneral cutaneous system are distrituted to the skin of the head without the intervention of specialized nerveendings. This sensorv system has components in the $V, I X$, and $X$ nerves. There are two principal central stations for these fibres: the Eeneral cutaneous nucleus, and the dorsal cornu of the spinal cord throuch the medium of the spinal $V$ tract. The two termini are really not essentially different, however, sirce the Eeneral cutaneous nucleus and the jorsal cornu are aorphologically continuous structures.

Fibres which have their termination directly in the general cutaneous nucleus may pass into their arborizations in relation to each of several eroups of neurones. What is probably the chief mode of termination is shown in Fig.5, E.c.f., where the fibre is seen entering the tangle of the substantia Eelatinosa. At no other point in Nustelus is there such a bewiloering naze of nervous processes as that presented by the neurones here. So far as structural features may be interpreted, it would seem that the substantia Eelatinosa is well adafted for the reception of the most delicate sensory inpressions. The larse nuaber of arborizotions found here indicates the real inportance of the Eroup.

Iermirations are also to be traced in connection with the 

deeper neurones of the nucleus. In Fig. $\curvearrowleft$ there is shown an incoming nerve-fibre, o.c.f., breaking up into its arborization near one of these neurones. The arborization is of the brosdIy digitate variety, spresding the disturbance over some slight area. The scattered distribution of the neurones at this point is doubtless a correlative of this fact.

Finally, the molecular layer which caps the whole nucleus contains many fibres of quite ninute size. This level, rith its small branching neurones, and the dendrites from deeper. zones, may serve to aistribute imfressions superficially.

Turning to the spinal V tract, this is a series of bundles of fiures which run posteriorly to the spinal cord. The bundles are scatterej through the deever part of the Eeneral cutaneous nucleus; refer to Eis.48,sp.V. General cutaneous tibres may enter the nucleus directly from the nerve of the same side, or through the medium of the arcuate bundles from the opposite sije. They may terminate at once in the nucleus, as describej above; or they may turn into the spinal $V$ tract for termination farther posteriorly. Some of those present in the tract are douctless branches of fibres which have ternirated ir part in the nucleus. The spinal $V$ tract, then, is a means for carrying great numbers of sensory nerve-fitres from cranisl nerves to the jorsal cornu of the spinal cord, eiving them a second and far wider hold.

The manifold central terminations of the seneral cutaneous system must have a sifnificance, if we can tut interlret 

the facts. The system is, priarily, a tactile apparatus for the head. Any one who has watched Nustelus exploring with his snout every corner of a new aquariua cannot doukt that tactile impressions from this region must have a large place in the lite of the animal. Nith practically no other check upon his visual sensations than can te derived from poking his nose into thines, widely spread central terainations of cutaneous fiures is no more than should be expected.

\section{Ihe Tubercilur Acusticum.}

The tuberculur acusticum is the trigeminal lobe of Viault

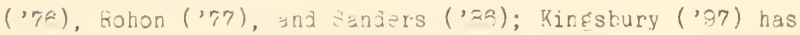
extended the term ceretellar crest to the entire structure; while Johnston (', $9 \mathrm{~b}$ ) appear's to include under his tuberculum acusticur all those structures in the oblonkata which are homolofous with the dorsal cornu of the spinal corj. The tern trigeminal lobe has been so variously usej that it should be aropped from our nomenclature. The earlier writers on the brair of the selachian so desisnated the tuberculum acusticum, supposire, erroneously so, that the Ereat uriEəxinal complex, which exeres just teneath its anterior end, must have the oriहgir of its nerve-roots here.

The tuterculur acusticun is the cringry terminal staticn for the acustico-lateral system. Fitres from the lateral line sense-orpans and the internal ear are components of the VIJ, 
VIII, anj X nerves.

The structure of the tuberculum acusticum embraces a mediocentral core in which bundles of nerve-fibres predominate; and an outer irvesting caf, the cerebellar crest (Fis.?,cb.cr.). The latter, in its outer levels, is morptoloeically contiruous with the molecular laver of the cerebellum, so that the term nolecular lauep is very properly applied here. The neurones of the tuberculum acusticum lie chiefly in the ceretellar crest, with just $\approx \mathrm{f} \approx$, also, in the central core. Trree varieties are to be distinguished: Purkinje neurones, oranular neurones, anj molecular neurones. I have so designsted them because each is the equivalent in every way of the elenent bearing such a name from the cerebellug.

a. Nolecular and Granular Neurones.-- The molecular and the Eranular neurones do not call for any extended description here, since they are directly comparatle with the cerebellar representatives described at length in Section $V$.

The molecular neurones are the most numerous of the three varieties peculiar to the tuberculum acusticum. They are found scattered throughout the molecular layer, most abundantly in the deeper levels. Each has the characteristically small cellbody with slender dendrites radiatiro from it.

The oranular neurones are far less numerous. They lie just withir the base of the molecular layer, but there are not enouch of them to form a jistinct zone. Strined with 

nethylen-blue, they exhibit the typical dense nuclear structure and the small amount of cytoplasm.

b. Purkinje veurones.-- The whylogenetic interest attıching to the presence in the oblongata of these elements calls for more special notice. The Purkinje neurones of the turerculug acusticum are not disposed in any regular order. They lie scattered between the deeper molecular neurones, and they are also found amon the छranular neurones. Their dendrites are alnays directed toward the limitans externa, whatever the situation of the cell-body may be, althoukh the exact course may be at a consideratle angle to the perpindicular. The axone alnays passes inwarl. Fefer to Fig.?, t.a.

The cell-body is slightly oval or even perfectly circular in outline (Eig.7). The particular form assumed appears to be correlzted with the position of the dendrites. The @narled character of a dendrite is quite evident. There are three or four of them, terminating in tlunt tips. A dendrite tears few branches, or none at 311 , and its surface is studaled with numerous thorny Eemmules of various sizes, some of them quite larke. The axone arises from the internal border of the cell.

It tskes a ventral course through the intervening nervous tissue into a bundle of arcuate filres. Its ultiate distritution has not teen Jefiritely tolloxed.

The internal structure presents a larfe nucleus with deeply stainir.g chromstin in the form cf a reticulum; and cytoflasm 
sonewhat less in quantity than in the cerebellar neurone, and holdine less tig̨roid substance.

From the above description of the morpholosy of the neurone of Purkinje from the tuberculum acusticum, it will be evident that it is strikingly like its earlier-known representative in the cerebellum. Compare, also, Fig.7 with Eig.1?. The neurone from the turerculum acusticum (Eis.7) is merely slichtly smaller in size, with a dendritic top which tranches somewhat less. The presence of conspicuous gemmules is characteristic of both. Ne shall take occasion to point out further on that the cerebellar neurone is to be regarjed as the more fully developed derivative of this element from the oblongata.

c. Termination of Acustico-Lateral Fibres... The fitres of the acustico-lateral system enter the tuberculur acusticum through the medium of the tbin neck joining the acusticum with the general cutaneous nucleus below. This fact is expressed in Eig.?, 3.1.f. It apkears, so far as they are traceable, that these fitres have passed over from the opposite side in the arcuate bundles. Penetrating the core of the acusticum, the fitres are at first associated in Erougs, but these soon become jissolved and the individual members spread throush the suter levels. The fine terminal tranches pass throuch the thorny Jendritic tous of the neurones of Purkinje, and the final arborizations are to be frequently otserved near the 

bodies of the Purkinje cells. Such a terninution is shown in Fik.7, 3.1.f. The nerve-fitre divides at some distance from the cell into several twigs, and from the portions of those nearest the cell-body several small terminal twies arise nhich form an arborization quite near to the cell. There is given in this way a direct nexus between the acustico-lateral fijres and the most conspicuous neurone of the tuberculam acusticam. Other eibres of ninute size evilently terminate in the molecd lar layer between thə small molecular neurones. Even here there would te an inßirect connection with the Purkinje neurones, for these send their jenarites into the molecular layer. Fitres are 1 lso to be seen in numbers which do not terminate in the tuberculum acusticuls at all. Some of these rengin in the central core, continuing anteriorly; while others are tranches of fitres which have taken a course into the acusticum for partial terminatior there. All of these pass upward to the cerebellum; they will be duly considered in Section V.

1. Theoretical conclusions.-- It has alresdy been pointed out that acustico-lateral components are not present as such in spinal nerves. Waiving the question of the origin of the system as 2 whole, it will rot be out of place to consider. here certyin problems relitive to its primary centre, the tuberculum acusticum.

The position which the tuterculum acusticun occupies in the oblongaty is inderj sifnificant, superposed, as it is, 

on tha cranial representative of the dorsal esrul, tha senerul cutanems nucleus. This tiat can only be taken to mean that the tuborculum acustiodm is phylogenetically the younter ot the two struatures in question. In Subsection 2 it a as shon that the pgeneril axtaneois nueleis has tha archaic strictural farturss of the dorsal cornu capped aith a molecular layar continuox Nith the cerobellar crest of the acusticum; and that thers are prosent hare both the molecular ael ls and the nexrones of Parkinjə. Ior this structural continuity aay slEniEy that the zcustican has been derived fron the Eeneral cataneous nucleus in tha phyloseny of the vertebrate narvous systan. If course it nill be nacjssapy to have a thorough stuly

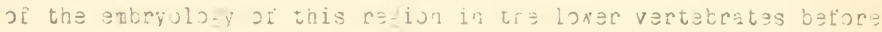

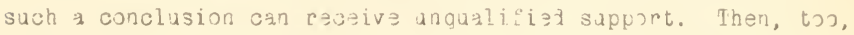
the rise of the tuberculati zcusticum has been but ore featuce in the evolution of the lateral line systen as a wole, and Sว $n \geq$ may confilently expect some assistance from tha further stuly of tha affinitias of its sense-organs.

There is somenhut nore soli.d ground for the beliet thyt tha tubarsulum zousticun has itselt siven origin to a vary important cesion of the brain, the cerebellun. The full evidanae on this point pill be presentel in Section $V$, sutsactis $r_{4} \approx$ 

8. Supporting tilenenti.

a. Eoendyna. - . The epenly in: ot the oblonfuta eonstitutes the menbrang linitals interna thesushaut, of course, bat tha legrez of dit'terentiation covers a nile ranse. The simplest conlition is found in the tela choroilex, for tne cells here lo not Eive orisin to epanjymal fibres. This misht be callel the epithalial phase of development.

The first step in the differentiation of epentyma sccurs in the dorsj-lateral resion of the oblonsata, embracins the tubarculum acusticum and the aljacent part of the general cutaneous nucleus. The epantymal cells are rather narrow hera, @iving a larsar numbor par sirïace area. Erom the tip of each cell, a very slenier epeniymal ibre pushes its way through the nervous matter to the limitans externi. The fibre loes not branch, and its general course is a straight one, although the details of its path are very irregular indeed, sharp turns of small size occurring flong its whole length. While the dianetar of the fibre as a whole is quite slender, its sizo is increased at irrasular intervals by bauls and small knobs. Sonsult wiE.?.

A slithtly more alvancel conition is to notel for the epentyma of tha vantrul region. The epantymal cells in tha tloor of the fourti ventriale are larger than those described zbove, and thein fibres are also much stouter. The peneril course of these fibres is shown in Fis.2, ep.; and the ietails of tas fibres are giver in Fis. 7 . It is to be noted thut the 

fibre exten ls entirely to the limitars exteris, that it bears no branches, that its course is tre from sharp turns, and that its diametor is varied by noles and taickenings of various shapes anl sizes. Sroups of these fibres forn raliating bands through the formatio retioularis, and their evident parpose is to provia stiys for tha vast umber of longituzinal an 1 arcuate nerv $3-t$ ibres which characterize this part ot the oblonsata. The ependyma attuins its highest diftorentiation in th: lotus vagi; see Eig.1). The fibres do not ratch the surface, and they give origin to a most complicatel serias of branchas at the level sccupiel by the neurones of the lobus. The proximal part of the fibre is gxite stout and somenhat irregular in its aurse. Iha distal part becomes lissulved in branches, tha terminal tsigs of which are minute. The interlacing branche.s forn a support for the neurones and nerve-fibres proper to this region.

b. Neuroglia.-- The nearogliz of the oblongati is, like tha epantyna, presant in ereat xiversity of form, but tha various elemant: ara referable to two onerial classes. Ine, tha Nell-knวan astrocyta, is distribatel in every part of the obloา हुata ahare thar? are nerve-fibres in numbers-- in tha rosts of nerves, in special tracts, in centres where many itibres have thair tarnination, and in the formatis raticulyris. The special form of the astrocyte iepenls, to some axtent at lerst, upon the densit, sith which the nerve-tibres are arranpel. At points 

where thare has been little pressure, the roundes incin of tae cell-boly may be retainel (Fig.3,ng.). In certuin closely packel tracts, the cell is squeezel into lenticalar form. In centras shere many minute fibras interlace, thare may be hardly any body to the cell at all, the mattor beins chieply in the raiizting processes (Eig.11). In every instance, the proc3s:3 exhibit tortuous ircestllaritios due to their insinumion between the nervo-fibres mong which they lie.

Anothar type of neurogliar cell appars to be characteristic of the vantryl part of the oblongzt;, occurring in some numbers in the tornatio reticularis (Fig.3). The cell-body is large, elongated, with grezt processes emereing lrom its en and a fen smaller ones tirom its sides. Tha laræe urocesses take a course in the ralius of the oblongata. They give orisin to seconjary and tartiary kranches, the finer ones of which lie at right angles to the course of the principal brunch. The shole systan does not spreal widely, but has the appearance of compression in one plane.

The astrocyte is evilently an important supporting element for the individual nerva-fibres between which its proc3zses twine. The secont class of neurogliar cell lescribed seams to be 31 int $\geqslant$ to th Eitres. The arcuate fibres of the formatio reticularis pass in eroups through the spreating brush of such neurofliar processes and are thərəby छivən sipport. 
9. Summary of the oblongati.

The stricturul fertures of the oblonsuty of Nustelus may be homolosizod with those of the spinzl corl to an unusuzl tescee of cleirnass.

The ventril cornu is representel by the nucleus of the VI nerve, and by the scatteres comissural and tract-neurones of the tornatis roticularis.

The lobus vasi is, morphologically, the centre ot tha viscero-sensory systom, but ther: has been annexed to it a conplax of paripharal sanse-oréans. It has come to be, therefore, the centre for the entire communis system, components of the VII, IX, and $X$ nerves. Endings are found related to neurones of the Golgi II type. These sand their axones toxard the viscaro-motor nucleus. Fewer fibres of the system enter the fasciculas communis than in either the teleosts or the amphibians.

The viscero-motor nucleus is the raprasentative of tine paracentral nucless. It is a morpholosically continuous column of cells giving origin to the motor fibres of the V, VII, $[X$, and $X$ nerves innervatine viscerz. The axones do not enter their nerva-rosts directly, as a rule, but through the metium of the fascicalus longitadinalis dorsalis. Some apperr to cross to the opposite side. Dendrites from the nucleus come into relation rith zxonas of the locus vyei.

The ganeral axtanejas nucleas is the homolofue of the dorsyl cornu. It is the primary centrefor the seneral cuta- 

neous components of the $V$, IX, an $3 X$ nerves. The substantia gelatinos* contains sroups of small Solpgi II neurones torminf Jense, felt-like tangles; many terainal arborizations are found in these. Other terninations sccur near larger neurones lying in the deepar parts of the nucleus. Many fibres of the systan Jo not terninate in the nucleus, but are carried posteriorly as the spinal $V$ tract for ultimate termination in the spinal cori.

The tubarculan acusticum is a phylosenetically young stracturs, not derivable trom the cord dinactly. It is the primary centre for the acistioj-lateril systen, components of the VII, VIII, and $X$ nerves. There are present, neurones of the moleclar, Eranular, and Purkinje types, identical sith those of the cereballum. Terminations sccur in tha molecular layer, and noar the neurones of Purkinje. The Purkinje neurones send thair axones ventrally in the arcuate bundles. The cerebellar erest is morpholo@ically continusus with the cerobellan. There is Erounl for balieving that firther investisation nill lerive the acusticam from dorsal cornu structares.

Supportins elpments are present in the oblongata in Erat numbers. There is triceable a wixe range of levelopmental forns of both nexrosliz and epanlyna. 

SECTION V.

THE CEREBELUTM.

The cerəbellun of Nustəlus is of large size in comparison with the adjucent brain-sesments. In the alult animal, it is of sufficient longitudinal extension to overhang the larger part of the midbrain in front, and also much of the oblongata behind (Fis.1,cb.). The base is only a third as gremt, howevor, indicating the smaller prototype from which the or san has been evolved. In fact, this cerebellan occupies an internediate position in the phyloşenetic scale, standing midway batwoen the simple plate-lika cerabellam of the cyclostoxe, the dipnoan, or amphibian, and the solid mass with radiating laminae characteristic of the mamal. It is essentially a great bulbous dilatation of the dorsal side of the neural tube, the Nall of wich has been thrown into folds as the process of groxth thrust the vesicle against the unyielding and more slowIy expanding craniur. So, instera of a solia central nass of nerve-fibres covered sith layers of @ray matter, we tini in Vustolus 2 hollon organ, the fourth ventricle extending free$1 y$ into it and ramifyine throdoh its sevaral folds. The folds, theroforə, ary simply doublings in the cerobellar wall, and $(33)$ 

arə f'undanentally difterent from the solia laminue tiamiliar to us in higher vertebrates.

Tha arrangement of the strictural elements of the cerebellum is readily followed, for in no other part of the brain are fistinctions pore clearly marked. Superficially, there is the molecular layer (Eig.12, m.1.); the granular layer lies naxt to the ventricle, or is separated from it only by the basal fibres (Fif.12.8.1.); between the two, there is the layer of Purkinje (Fig..12,p.l.).

The nerve-fibres of the orsan are found in two well-defined groups, the basal fibres and the median fibres. The basal fibres (Fig.12,b.t.) enter the posterior reşion from the obloneqta and soon become dissolved in the outer layers. These fibres lia next to the ventricle, and they supplant the oranular layar entirely during their course, or at least lisplace it quite laresely. The median fibres are disposed in scattered bunlles which lie in the outer part of the granular layer just beneath the cells of Purkinje. The bundles take tro seneral directions: transverse, (cut across in Fig.12, m.f:); and longुtudinal, extending parallel wita the stractural zones (甘iE.12, m. f.).

1. The Neurones of Purkinje.

The neurones of Farkinje are the laresest, and by far the wost impressive structiryl elements of the cerebellum. Their 

cell-bolies are disposed in a thin strutum interialated betueen the molecular and the granular layers. At those points where tho granular layer is absent, the Purkinje cells come into direct contact with the layer of basal nerve-titres, insterd. As to superficial distribation, the neurones follon a welldefinad rule (Eig. 12, p.1.). They are most numerous on the sides of a ceræbellar fold, often several cells in depth here, and not infrequently having their cell-bodies in contact. At the sumit of the t’oll, ther? are wixor spaces betwaen the individual cells; and for a small space at the bottor of a fjold, the cells ars absent altogether. The posterior told of the cerabellum has a part of its area sithout Purkinje neurones. Fi̊. 13 illustrutes the teatures of external morpholosy charzcteristic of z neurone of Purkinje. The cell-body is situatex, as already notex, at the base of the molecular layer. The denarites, therefors, હron upsard into the molecular layor, and to thaic presence hars is due, in part, tha marked striation perpinaicular to the surface which is so characteristic of this suporficial zone.

The axone alizays arises firom the base of the cell-body, and it pursues a horizontal course for some distance. It then turns downard throxh the granular laver to enter the systen of fibres leaving the cerabell $1 \mathrm{~m}$. Whare the granular layer is absent, the axone may be traced into the layer of basal tibres for a still Érater horizontal course. Ihe axวne is remarkable for the fact that it loes not Eive off collateral tranches. 
t. 
The cell-boly appass to have its torm detarnined quit? largely by the number and disposition of the dentrites arising from it. It may be counded, oval, or even triangular in outline. The longer axis of the cell, wile usuylly perpiniticalar to the surface of the fold, may be oblique or still farther tilted over from the orientation characteristic of it for the hiogher vertebrates. Even the size of the cell is intluencet by its position. Tha dianeter is grentest in those cells lying at the part of the fold where the side curves atruptly into the summit. On tha sides of the fold, the size is remarkably less, and the dendrites pass outward at a wider angle, often causing the cells here to assume a horizontally elongated forn. The cell studied by Szczaninska ('38) evidently as of this latter type.

The internal structire of the Purkinje cell is demonstratad less radily with methylen-blue than is the case for most nerve-cells of Mustelus. In successful preparations, however, the cytoplasm is found to hola tieroid masses of triansular or spindle-shaped form. These bodies are neither larse in size nor many in number. There are alkays several of the Ereatest diameter arranged near to and concentric with the nuclear membrane. The thick bases of the dendritas have siall, narron, lenticular tiegroils bistributel spurinsly as far as the level of the first great branches. The charactor and distribution of the tigroix-bodies sill be seen by reference to Fie.4.9. The nuclexs of the cell lies in a tasal position, but it 

is zlvays bordere? by some little thickness of cytoplasm. The forn is oval or circular, with an almost even contour. There is one larse nucleolıs, Nith a subsiliary nucleolus in some calls. The nuclear reticulam has a rather fine mesh; larşe Eranules of chromatin sccur at the points of intersection.

The denirites arise from the peripheral site of the cellbody, and they pass at once into the molecular layer, takins $z$ dicact course for the linitans externy. The size of a dentrite is maintyined without narked ximinution, the tip, in fact, being so larse ank blunt as to sive a club-like appearance to the rhole process. The mode of branching is far simpler than that of the corresponking mammalizn neurone. While tha dendrite of the latter camifies to an extrasrinary degrea, it is rare to find branching carried bevond tha tertiary divisions in Mustelus; compare my Fis. 13 rith Plates 14 and 15 of Starr's Atlas (,9a). From its greater simplicity, the selachian neurone of Purkinje corresponds, in a browd say, to the embryonic condition of the higher forn. The branches are spresil in one plane, likə a plant trainet on a rall, anz this plane lies transversely to tha cerebellar folls. The course of the branches in this plane is less rile than for mammals, causing the whole top to present a markexly more compact apparance. The surfaze of a denlrito his tha conspicuaus roughness chariuteristic of this neurone wherever found. The Eemmules, to which this roughened surfuco is tue, are of several tifferent sizes, rangins throush mere points throush slenter spines anl stouter 

thorns to knobs and mushroom-like excrescences whlch rise lar above the general level. The extəut of receptivo surlace of the entire deniritic serias is thas incremsed to 2 very considerable degree.

The part ahich the neurone of Purkinje takes in the econony of Mustel:s vill be discussel in Subsection 5.

\section{The yolecular Layer.}

This is the external layer of the cerebellum (tig.12, m.l.). It conforms throughout to the contour of the sevaral folds into which the cerebellar wall is thronn. Its trickness is carried nith consiaerable unifornity, but in most of the reEions the depth of matt $\geqslant r$ is only about half as much as that of the granular layar xithin.

The molecular layer is characterized by the prejominance of fibrous elements and the fewness of nerve-cells. In contrast rith the mass of densely-packed, conspicuous cells of the Eranular layor, the outer region presented harily more than 2 minutely punctate appearance to the earlier investisators who had recourse to nothing more differentixl than the generil stains in use at that time. Hence molecular seemed an appropriate lescriptivo tern for this layor.

Throush the use of modern methods, we find tha molecular layer to have a fen proper neurjaes of' small size, but tine હrant mass of substunce consists of tibrous material, betroen 
the parts of which the nerve-cells are intercalated. But, it is certainly a fact worthy of mention, the Eibrous constituents of the layar do not have their origin thars, penetrating it, rather, from dəepər levels. The dendrites of the Purkinje neurones, and the processes from the neurosliar cells comprise one grat class of constituents. Thase take a course pərpindicular to the surface and cause tha vertical striation which is so marked a feature of the resion. Than, too, the neurones of the eranular layer sent their axones outard into the molecalar layer for a T-shapel livision, each thus giving origin to a pair of fibres. These branches take a course across the sasittal plane of the cersballux, parallel at once with the limitans externa and the lataral surface of a fold. To the presence of these fibres, cut across in such numbers in 2 sagittal section of tha cerabellun, the characteristically punctate apparance of the molecular layer is chiefly due. Finally, it should also be note1, there are numerous terminations in the molecular layer of nerve-fibres shich have antered the ceraballan from some othar resion of the nervous system. Such terninating fibres branch so as to distribute the endings Jvər a consiler»ble superficial zre幺.

It will tius be seen that tire molecular layer is really a tangle of nervous tissue, a series of paths where many associations nay be forned. This topic sill be discussel more at lenghth in the fifth sibsection.

The neurones proper to the molecular layer ace, as alrayly 
noted, but fen in number, and those present sre scattered betive sh the nerve-tibras. The externyl torphology of one of thase naurones is representel in Fig.14. Erom a small, almost perfectly spherioal cell-body, three or four iendrites ratiate, branching in what is an approach to dichotomous anner. The denarites are not thick at their bases an 1 they become lost to vien before proceeling far, owing to the fineness of the terninal twiss. The surfuce of a denirite is almost pertectly smoth, there being only the faintest indication of Eemmies, but there are saall varicosities at irregular intervais which profuce slişht variations in the thickness.

The internal orફ̧nizition of the cell presents a larga, rounded nucleus which is env 21 oped by a stratum of cytoplasm of no great thickness (Eig.5)). The cytoplasin contains tigroid substance distributex in granules of the most minute size, mere points even when highly magnified. The chromatin is distributed along $a$ linin reticulun of such fine mesh that the nucleus is tharaby often made to appear almost porfectly black. There is a single nucleolus.

In mammalian neurology, the molacular layer is known to have tro varieties of cells: (1) Stellate cells, the processas of wich lie freely in the layer; and (2) basket cells, somexhat larger in size, occupying the deeper levels of the layer, and having their axones associzted with each othar in such 3 ray as to form plexusas or baskets arouna the cellboties of the Purkinje neurones. The latter type of cell is, 

of course, the more spacialized of tha tos. It is tharelore interesting to note that it is not reprasente? in Mustelus, but that all of the nolecular cells corrasponi, rathar, to the stellate cells of higher vertebrates. Such a rəsult is, however, to be expected in a bruin of lower phylogenetic value.

\section{The Granular Layer.}

The grinular layer lies interial to both the nolecular layer anł tha neurones of Purkinje. It is someahat irregular in its listribation. At many places it is trice as thick as the moləcular layar, notəbly at the sumits of the grazt folis; While it tents to zecraxse in extent as the bottom of a foll is razched. A saeittal saction of the antire cereballum shows 3 fen rəgious wharə the granular layer is absent altogethar (Fig. 12, s. 1.).

With nuclaar stains, the Eranular layer appears to consist of a vast numbar of lensaly packed, rounded nuclei, from which fact the names granular and nuclear have been appliei as lescriptive tarms. It is only through the application of metallic impragnation that the real character of the elements and the relations betreen them have been deternined. When thus demonstrated, ther? are to be racognized neurones of tho distinct varieties, the Eranular, proper, and the Golsi neurones. 

neurones comprising the granular layer are included in this class. The distinctive feuturəs of such a neucone (tí. 15) embrace a rounded cell-body havine a fen short dentritos, and an axone which ascents throush the levels of the eranular layer above its point of oriein to the molecular layer, ahers it divides in a T-like manner.

The size of the cell-body varies slishtly, but it is alnays smallar than a neurone of Purkinje. As to shape, there is consiarable diversity. The derivative form appars to be a rounded one, but this has been subjectel to much molification by the orişin of the dendritəs so that triansular, rectangular, and variods poly อ̊onal sutlines are Eiven.

The internal structare of the cell, (Fis.51), consists chiefly of the nucleus, only the faintest halo of cytoplasm bəing visible at any point; even the bases of the deniritəs can hardly be ræcosnized sith paraly cytolo@ical stains. Demonstrited vith either methylen-blue or iron haematoxylin, the nucleus is found to contain a fen very coarse and irregular chromatin granules strung on fine interlacing threads of linin. The presence of a nucleolus is doubtfil, at least it is difficult to distinguish one from the masses of chromatin. Fié. 51 also shors how closely these neurones are packed.

The dendrites are three or four, only, in number, arisins from the cell-body ti approxinatoly equidistant points (yig.15). A dentrite is short and narly alsays relatively staut. Its course invalves sinuous curves. It branches bat 

rarely until the tip is remched, ahere it dissolves into brush or a series of hooks spreadins over a relatively consilerable area. There are no semmiles.

The axone is excestingly slender. It may arise dirzctly from the cell-body, but it ususlly takes its orisin from one of the dendrites, either near the base or at some distance from the cell; Fig. 15 illustrates the two modes of formation. The course of the axone is invariably peripheral, pushing through the intervanins thickness of the granular layer into the molecular layer. At the boundary between the two layers, the course changes abriptly to a horizontal one for a short distance, and bence the entire course of an axone can rarely be tracej in one section. In the molecular layer, the axone divides into t*o branches which, with the orisinal stem, torm a T-shaped figure (Eig.16). The tio tranches pursue a course parall ll sith the surfice of the cerebellan and the siles of the fold in which they ran. It is thus seen that they pass throush the dentritic tops of the neurones of Purkinje, comparable to telephone xires passing through the tops of the trees alone 2 hiogh

\section{b. Solzi veurones.-- A fen neurones of the sranular layer} have an zltogether difterent character from the ones just iescribet. These lie in the apper levels of the layer. Such a neurone is shown in tik.17. The cell-body is alsays a littlo larser than that of the typical sranule neurone, and its form 

is nore roundex. A fen club-like dendrites rylizte from it for a short listance, branchino but sparsely. The size of a dendrite is increasel at intervals by sliont swellinfs.

The axone passes donnsari into the deeper levels of the granular layer, instazd of upNard. It gives off collateryl branches soon after its orioin, and it braks up into a number of fine terninal toigs bafjore any graat distance has təen traversad.

This neurone is homolocous with the variety Jescribed by Solgi ('94) from the human cerebellum, and by him made z representative of his second type of nerve-cell. The branching of the axone is far less profiuse, hosever, than in the mammal.

We thas see that the Eranular layer of the cerəoellam of Nustelus is marked by the presence of the same varieties of neurones which charactorize this layer in hioher vertebrates. The morpholosy is somenhat more simple in the selachian, as should be expected, but it is a suggestive fact that the strictural plan of higher forms is here outlined in its essentizl fieztures.

\section{Supporting Elements.}

The supporting elenents of the cerəbellum are referable to botin the ependynal and the neurogliar series, the former being limitod to the franular layer, and the latter to the molecular layer. Tha structury in each instance appears to 

be particularly adapted to the supportinf of the nervous nechanisms peculiar to thesa rasions.

a. The Epenlyma.-- Ihe epenlynz of the cerebellan presents the usual palisate of closely cronded cells forming the menbraaz limitans interna (Eig. 13). The cell-body is irrosularly pyramilal in form, the siles rarely tapering evenly to the apex but exhibitinE more or less bol a curvatures of outline. Erom the apax of the cell-body, 2 process, the ependymal fibre, arises, and this pursues a course through the structures of the Exanular layer to near the suter linit of that zone. I have not found a single instance where one of these fibras passel bəyoni the Łranular into the nolecular layer, z fict of some possible phylogenetic value, indicating the more ancient character of the internal ragion.

The ependyma-fibre is relatively stout, but its diametar is far from uniform. There are fibres which have portions of the lensti four or five times the thickness of the intervening parts; seə Fif.12,b. Jccasionally, knobs and other rounded thickenings are found, particllarly at angles where the course of the fibre changes abriptly. The treni of the fibre is never conspicuously irregular, only such slight turns and winjinss Jccurring as might be expəctei nhere obstructions are present luring the periot of Eroxth. The seneral trand is diractly toxard the surface of the ceraballar fold, the sevaral tibres lyine nore or less nearly parallel with esch other. 

The leģree of brunching exhibits aile diversity. Certuin fibres (Fis. 18, a) have some halt-dozen principql branches of various lengths, none of then very lone nor diversine videly from the main stem; besiles tha principal tranches, there are shorter trigs distribated sparingly along both the main stem and its ramifications. Other fibras (Fis.19,c) are so beset with a rultitude of small toiss, quite irresular in their tranching, that the whole series is Eiven much the appearance of $\Rightarrow$ long and cylindrical trush. Betiaen these tro extremes, there are every intermediate condition of branching forns.

The ependymal fibres lie quita near to each other, and the many processes irom them constitute an interlacing tanele, the profision and extreme delicacy of which cannot be alequately represented in any jrawing. In order to appreciate the sipnificance of this dense supporting framenork, the vast numbar of the granular neurones must be racalled. Here se find the means by wich these nervous elements are Eiven that support which is one of the primary conditions for thair activity.

b. Neurogliz..- The neuroelia proviles a support for the outer strictures of a cerebollar f'old, just as the ependyma functions within. The characteristics of neuroeliar elements are shonn in Fig. 1.9, ast and bg.?. The cell-body lies at the junctire of the molecular and srinular layers, between the cells of Purkinje. Iro conditions ara to be distinsuishel. One variety (Eig.19, zst) has a cell-body of quite irresular 


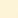


outline form ahich many processes rutiate. These processes raraly branch. Some of them may proceed to a distance equal to several times the orauter axis of the cell, but most of the branches are far shorter. They are placed so closely zlonf the marsin of the cell that the whole has something the eftect of a halo. These cells are clezrly homolosous with the astrocytes of hioher vertebrites.

The other type of neuroolia cell (Eis.19,be.f.) is referable to the catesory of Bersmann's fibres of the anmalian cerabellim. The cell-body has fener processes than the astrocyte, but it gives orişin to one stout fibre which takes 3 peripheræl course, sithout branching, throush the entire taickness of the molecular layer. Ihe path of the fibre is not one directly towart the surface, for it runs almost parallel nith the layer of Purkinje neurones for a short distance; it then tarns upward, terninating at the limitans externa in a conic2l expansion. During the proxinal part of its length, it bears fine processes similar to thos emerşing from the cell-body. The distal part of the fibre has a remarkably vast number of fine processes. These may remain separate tirom each other, but at intervals they become mattex together so closely that the whole has the appearance of lelt or even that of a solix. The account piven by Schaper ('98) of whyt he took to be Berฏึann's fibras does not corraspond with my finaings in several particulars. This author joes not mention the processes of the cell-boly, nor do his figures show them. It may be thrt 

his preparations were insufficiently impragnated. Neisht is given to such 9 possibility from the fact that ho did not finl gstrjcytes at all. It is certuinly of some phylogenetic interest that Beremann's fibres appaur to be jerived from astrocyt?s. I have found numerjus i.astances shere transitional forms are recognizable, linking the extremes of the simple astrocyt? Nith the one provized with a lone process, the fibre of Berśmann.

The position occupied by the cell-body of a Beremann's fibre is also significant. Kölliker ('99,0.363) stutes that at birth Bersmann's fibres in mammals lia at the boundary of the eranular and nolecular layers, and that during growth they normally mierate into the Eranular layer. Now the parmanent position of Eersmann's fibre in Nustelus corresponds to the embryonic state in the mamal. An additional comparison may be institated regarding the form of the fibre, the adult element of Wustelas remainin@ simple, while the mammalian fibre becomes much branched. That the condition in Vustelus corresponds to the emtryonic stace of development in higher vertebrates is, of course, no wore than should be expected.

The chysiolosical interpratation of the cerebellar neuroglia is not difficult. The numerous processes from both the astrocytes and Beremann's cells provile a delicate suspensory apparztis for the neurones of Furkinje. The oreit Eerśmann's fibres, razching upward as they do throush the molecular layer, may be likened to sว many telegraph polos; and the mattad tan- 

Eles extening laterally from these are the cross-bars for the xires. The rires to be supported, folloning out our comparison, are the harizontal axones of the erunular neurones, which, as we have already noted, extand through the molecular layer in larģe numbers.

5. Arshitesture and Physiology of the Cerebellum.

It is now a vell established fact that the principal function of the cerebollam is to presile over the equilibration of the body. Noræover, a fiarly direct connection is traceable between the morpholosy of this segment of the brain and the nature of the muscular activities which are characteristic of the animal. To the student of comparative neurology, therefore, the cerebellam holds problems of a special order, and is ever potential with no mean interest.

Ne have seen that the cerabellun of Nustelus ratains an external form of a far lower orjer than that found in the birl or mammal. The internal orsanization is not so inferior, hoxever, as we misht, from this fact, be lex ts infer. The architecturyl featur»s of the loxer and the hi gher types are so similar that the contryst is really one of desere and not one of kind. In both instances, the same sorts of neurones ara present, £roxped in a sinilar $x a y$, and related to each other physiolosically in assentially the same connections. This remarkable identity of t'eatıres can only te intəruretef to mean 
that the cerebellum became established in its orsanization quit? azrly in the history of vertebrates.

Undoubtelly, the kay to the significance of cerebellar structurs and physiolosy is to be looked for in the nemrones of Purkinje. These strikine cells, with their characteristic trəe-lika tops, apparently have all of the other structiral elements present arrinsed contributory to them. Imbedded in the midst of the nervous matter, supported by the interlacins processes of the neurjofliz thers, a Purkinje neurone sents its Ereat branching denarites outvard into a veritable maze of possitle physiolosiczl connections, for such the molecular layer railly proves to be. We have seen that the Eranular neurones contribute their axones to a series of fitres passing horizontally throush a ron of sprazing Purkinje dendrites; that the neurones of the molecular layer are themselves radiately connectine paths; and, finally, that the incoming nervefibres, those arisine outside the cerəbellum, end, some in the Éranular layer, others taking a longer course into the volecular layer. These severzl elements evidently have no other purpose than the bringing of all incomine impressions, through one path or another, to bəar upon the neurones of Purkinje. The enrəzt sprezding top of a Parkinje cell is obviously a device for providing a large receptive surfice for such impressions, wile the many thorn-like eemules with which the Jendrites are studded serve as q Eraţar extension still of that surfice, or, perhaps, make one shich is more readily impressed. 


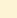


The axone of the cell takes a more or less iirect course out ot the cerebəllum, carryine the resultant of the nervous intermetions to the proper point for altimate distribution. If it is the parpose of the whole series of cerebellar elements to provile a central mechanisu of equilibration, then the neurone of Purkinje is certainly the centre of that mechanism. The various nerve-ficres sweəpinf into the cerebellam may terminate in several ways and at jiverse levels of the orean, but evervwhar? ther ara devices for connecting them physiologic$21 \mathrm{ly}$ with the neursnes of Purkinje, which receive all and preside over all.

The researches of Lee ('32,' $92, ' 34, ' 93)$ upon equilibration in fishes have shown with what nice aiscrimination these aquatic animals balance thamsalves, devoid, as thay are, of many sources of impressions possessed by terrestrial vertebrates. Doubtless a larşe number of equilibrial inpressions are derived from the visuzl mechanism of the fish. Axones from the roof-nucleus of the midbrain pass backwart into the cerabellum; and it will be shown in Section VI that there is a most intimate associztion between the root-nucleus and optic terminations. Another source of aquilibrial imprassions is to bə found in the fins and body musculature, enterinf the cerebellum through tha tractus cerəbello-spinalis. But the rork of Lee clearly demonstrates the overshadorine importance of the piscine ear as a peripheral oraan of equilitrution. In fuct, his latest rosearch (', ga) makes it clear that the prout ear of 

Nustel is is not a true auditory orsan at all, but thut its severyl parts are to be interpreted from the standpoint of the equilibrium sense. The larke nerve-tracts from the ear to the cerəbellam arə, therəfore, definitely sienificant, beins thə connecting fibres between the centrul mechanism and its most important peripheral organ. It also appears that not only does the ontopeny of the ear shon its relationship to the lateral line oreans, tut the fanctions in the tro instances are comparable as nəll.

An analysis of the hacits of vustelus will, it appears to ne, ఏ๐ far tonard explaining the disproportionately @reat development of both the aar and the cerabellum which we find the animal to have. This shark, although a comparatively small reprasantative of the sroup, is, withal, a restless hunter of the seas, ever ursed onward by an appetite which, apparently, has no bounds. Continually suspended in a filid melium, and compellet to balance itself at every turn, the animal requires a precise mechanism of equilibration. Ihis is to be found, in the wais, in both an ear and a cercbellum levoloped to a degree out of all proportion to the scule occupied by the creature as $q$ hole.

8. Euolution of the serebellum. Evilence of the orisin of one bryin-structure from snother is usually of the most meager value, but it appears as though 

it Nere now possible to neave tosether a fen scytteral threy is in the evolution of the cerebellum. Schaper ('94) has called attention to certuin facts in the embryology of the teleostean ceraballum which may be taken as the startino pjint. The ceryballam arises in ontogeny, not as a bruin-sesment having the full value of the others, but as a paired thickening in the parietal walls of the neural tube at the anterior end of the oblongati. These thickenings gron upNard and reat each other in the nedian line. Schaper has since extended his studies to 211 classes of vertekrates, and he finds (',9.9) that the antərior limit of the bilaterılly symmetrical anlage may be definitely fixed, coinciding with the boundary between the primary mit- and hindbrain vesicles. The posterior limit of the futıre cerabellim is by no means clear, honever, for it seems to merş backwarl into the oblonpata. These are certainly siognificant facts.

It as sho\%n in Section IV, Subsection 7, that the molecular layer of the cereballum is continuous with the cerabellar crest of the tuberculum acusticum, maintaining essentially the same morpholoहुicłl characters throukhout. It was also shown that there are present in the tiberculat acusticum neirones which are ilentical nith those of the cerebellum-- molecular neurวnes, Equndlar neurones, and Purkinje neurones; the last tro varieties are not Erjuped into jefinite strata, however. The presence of Eranular neurones in the acusticum is worthy of renark, but the હræutest weisht must be attached to the 

t'indino of Purkinje neurones here. These neurones ners lone supposed to characterize the cersbellum alone, and their strikinsly peculiar appearance makes them readily identified. The neurones of Purkinje from the acusticum of Mustalus gerəe $x i t h$ those from the cerebellum as to size, eneral form, shape and character of dendritic top, and even in the presence of the spiny Eemmules so charactoristic of this nervous element. There can be no question as to their morpholopical ixentity in vustelus. Johnston ('93b) has found Purkinje nearones in the acusticum of Acipenser, somenhat smaller and simpler than those of the cerebellum, but andoubtedly equivalent. Similar results Nill probably be obtainal in all of the simpler vertebrates. It ray be concluded, in the lisht ot these embryolosical and strictural facts, that the cerebellam has arisen in the phylobany of vertebrates as a fused outoronth of the pair of tubercula acustica. The acusticum is the primary end-station, as ae have seen, for the nerves of the ear and the lateral line organs. The cerebellam has been differentiated from the primary ending as a special centre for presiaing over equilibration. Farallel with the increasing development of the equilibrial sense in vertabrates, the cerebellum has erudually acquired associations sith other than the orisinal source, so that the fibres entering the organ have ever bəen હ़rosing more numerous, and the bulk of the fibrous centre consequently more massive. 
7. Sumnary of the cerebellim.

The cerabellum of Mustolus is of relatively larse size, and, althoush remainine in the prinitively hollon condition, its wall has the sane essential plan of structure as the orkan in hisher vertebrates.

Neurones of Purkinje form a zone, crowled at certain points, between the nolecular and the granular layers. Such a neurone has the structural features characteristic of its mamalian representative, but sith a simpler branchins of dendrites. Its office is to receive incomine equilibratory impressions.

The neurones of the molecular layer are $f e n$ in number. They are all of one variety.

The neurones of the granular layer are of two kinds: Golfi neurones and granular neurones. Tne former lie in the upper strata of the layer. The હranular neurones are strikingly like those of hisher vertebrates; their axis-cylinters branch in a T-shaped manner in the molecular laver, meliatine between many inconing fibres and the dendrites of the neurones of Furkinje.

Ependyma is developed into a profusely branching fibre which extends throush the Erunular layer, only.

Neuroeliz provides a supportine framenork for tha naurones of Furkinje and tie nolecular layer. Both astrocytes and Fert́mann's fibres may be reconnized, but there are transitional forms indicatins that the latter have been lerived from the former. 
The larse size of both the ear and the cerebellum of Nustelus is to be explained by the swimmine habits of the animal. The structires have an equilibrytory vilue.

The cerebellum has apparantly arisen in the phylogeny of vertebrates as a fusel outorowth of the pair of tabercula acustica, a specializytion of that part of the obloneata formino the oridinal terninal station for the acustico-lateral syster. 

SECTION VI.

THE NIDBRAIV.

Tne mitbrain of Nustalus has retained to a marked degrəe the features characteristic of this cerebral vesicle in its primitive condition. Its ventricle has been so little encroachad upon by nervous mattor that the name aqueduct of syluius rould not be applied as a descriptive term xere it not nade necessary by usase in hicher vertebrates. The aqueduct is produced laterally into a pair of spacious recesses, each of which occupies the intorior of an optic lobe, shile the general cavity comnunicates freely tirough narrower extensions with the third ventricle in front and the fourth ventricle behind (Fiฏ.1,mb.). The optic lobes are tro thin-nalled bodies of dome-like form, separatel from axch other by a conspicuous median furrox, and the pair taken together are someshat broader than the base of the mixtrain on which they rest. The anterior divisions of the cerabellun lie upon and partially conceql the optic lobes from the dorsal aspect. The base of the mi abrain is a direct continuation anteriorly of the Ereat titresystems of the oblongata and metencephalon, shorine but slisht Birinution in size. 

The microscopical angtomy of the milbrain is reslly quite complicatet, owing to the diversity of the terminations and connections wich are established here. The base is a crosuad hishway betreen the ditterant parts of the encephalon. Ihe fibres of the optic nerve have their termination in the dorsal mijbrain, the tectam mesencephali, with a nexus of intrinsic neurones and fibres of more distant orioin associated with them. Finally, the aquejuct of Sylvius is borlered by nervous matter which is phylosenetically listinct from either the base or the tectum, and this has underşone special development at certain points as the nuelei of inportant motor neurones.

\section{The Tectum Vesencephali.}

The tectam mesencephali lies as an investing cap upon the central gray mattor shich surrounds the aqueluct of Sylvius, Its sitiation here is fraught with sisnificance, for it reprəsents an addition to the more ancient nervous structaras made necessary by the development of lateral eyes in the vertebrate phylum. The tectum anbraces the central expansions and assjciated connections of the nerve-fibres having theic ori sin as axones of the retinal neurones. Certain neurones of the tectum may, also, sent their axones outward into the optic nerve. The ahole complex is, in fioe, the prinitive visual centre.

The tectum of Nastelus does not quprowch the extreme deÉræe of differentiation which kamón y Cajal ('3.9,',91) has le- 

scribel from the optic lobes of birls, but it is prycticable to distinguish three zones of structural elenents: the layers of the superficial, the midile, and the deepar neurones, respectively, (Fig.21, sn., m.n.,a.n.). VanGehuchten (·34) nas lescribed three zones from the optic lobe of the teleost, but these are not exactly equivalent to the layers aoted here. his couche noléoulaire appears to incluje both my superficial and midale layers; his couche granuleuse corresponds in position to my deeper layer; while his couche des cellules épenilymaipes is an inner zone which apparently does not include the central §ray mattər.

a. Teprization of the octisus. Str. Yeiullare Profundun.-- A Erat bundle of fibres may be traced dorso-posteriorly from each angle of the chiasma to the sptic lobe, shere it becomes dissolved through sprealing over the surface. A section shors that the fibres in the outar zone lie parillel with the surface during sore little part of the lenth of their course, and that they then pass dornara into deaper parts of the tectur. Fine branches are given of neuranes of the mixile and deeper layers, and many terminations appazr to occur here. A certain number of fitres, horever, pass to ever deeper levels, tendine to become collectez into bunlles, and they finzlly blend into the strutam mejullare profindus.

The strutum melullare profindum is a conspicuous featur? 

of the deepest part of the tectum mesencephali. At the crown of the arch shich the optic lobe presents in section, the fibres are seen as Erat horizontal bundles interrupter at almost perfectly repular intervals by small éroups of vertical fibres. The tro lateral halves are united by a strons commissure just dorsal to the zqueduct of Sylvius. Fis.?), s.m.p., represents these tieatures in a transverse section.

Traced laterally, the fibres of the stratum meiullare profundim are found to pass into the base of the milbrain in two soraenhat clearly marked divisions. The outer division takes a larô number to the lateral surface (Fis.२),e.l.); while a markedly smaller group passes downward nearer the median line for a ventral decussation (Fig.?o,i.l.). The inner division is composed of those fibres lyine nearer to the central Eray matter from the outset. Some of these have but a short course donnari and outrar 1 , but the great mass of fitres continues Dear the median line as a series of intercrossing bundes ahich zre destined to decussate ventral to the aqueduct of Sylvius (Eis.27, ๖.m.,i.m.).

The fibre-systam composine the stratum melullare profiundum nust be indeed important in the economy of the brain. Ints this systam we have tracel fibres from the corl and oblongata, fitras from the optic narve, and from the nexrones of the tectum mesencephali itself. Te will subsequently have occasion to point out that a grat tract sweaps into it from the intarbrain as a relay in tha olfactory apparatus. Fitres are also 

present here from certain of the cranial nerves. All of these fibrə-systems from diverse sources are to become related to the remarkable mechanism ot Reissner's fibre. It is certuinly evident that there are here every means for intercommuication between different parts of the nervous system, a sitich-boart, so to speak, of extruorinary possibilities; but to this subject $x \geq$ shall return further on.

b. The Superficial veurones.-- The outermost layor of the tectum mesencephali is characterized by the predominance of aerve-fibres and by the feeble development of its neurones. Receiving as it does the fitres of the optic nerve for their first expansion, ne shoula harkly expect a high degree of nervous activity here. There are a f'en scattering nervo-cells present, however, (Fis.21,s.n.). These are quit? ninute in size, lenticular in forn, and are disposed with their long axes tangential to the surface of the brain, as though squeezed into crevices between the mass of nerve-fibres. The internal organization of the cell presents no features which rould mark it as having any deçree of importance physiologically (Fis.52, s.n.).

c. The viddle veurones.-- The neurones which lie in the midale layer of the tectum are characterized by their larser size and vastly Ereater numbers as compared with the outer rasion. In fact, the number is so Erat that in a section, 

the nerva-colls often appanr superpasel one over another, ant the processe: a ake a veritable tangle of interlacins branches (Fig.21, m. n.).

The neurones of the level are to be distinguishel tron those of the deeper layer, on the other hand, both by their compactness and by thein mole of branching, which is of the ratiatins typo. The several processes of a nerve-cell spreal out and branch frealy in all directions, but they do not extend ear away from their points of orisin. A representative forn is arawn in Fis. 22. There are alnays several dentrites, and these may arise either from the outer end or from the side of the polyganal cell-body. The branching begins guite near the oriéin, so that the size diminishes rapilly from the base outnart. The dendrites of the outer extrenity have their finest tsigs penetrating the superficial layer of nerve-fibres. The dendrites arising from the sides of a cell interlace more larsely with those of other neurones. The surface of a dendrite 3lings bexrs an zbuntance of simple semmules.

The axone parsues an irregular course, often surezins over a considerable horizontal area, but the seneril trenl is ever torard the center of the brain. It gives off a sreat profusion of collaterals as it proceeds, and the final ternination is found at no छrest distance from the coll-body. There is here, then, an illastration of a cell of the Golpi II type. The several ranifying axones lie in the repion occupies by the cells of the deepar layor. 

The nuclexs is a roundet, centrally locatel body, fillins the larser part of the mass of the cell. The cytoplasm hol ts 9. fen tisroid-bodies of small siz?, an evilence of q lon order Jf metrbolic zctivity in this type of cell. Fig.52, m.n., exhibits what details of internal orsanization are visible under the hişhest amplification.

The part wich the neurones of this layer take in the physiology of the optic termination may be inforrel with some degree oi certainty. The lense tanole of lendrites just beneath the inconing optic fibres constitate a larese surface for purposes of reception. The spreiting axones in the layer benath afford, with the neurones there, a physiological nexus of some superficial extent, possible paths of association, if a choose to apply the tern here. Ne will return to this subject in the folloring subsection.

d. The Deeper Veurones.-- This layer is thicker thmn both the precedins ones put togetiar. The neurones are less closely crowded than those of the mitale layer, and they lie in groups between the bundles of optic fibres passing downard to the strutun nedullare profundum (Eig.z1, ג.n.).

The neurones which give ch»rłcter to this layer are lonsdrann-out, the dendrites extendins nearly to the external surface of the bryin, and the axone reaching xell toxart tie linitazs interna. Fis. 27 shors a typical neurone consilerably enlarzed. The cell-boty is spindle-shaped or oval in outline. 

Fron its outer and, a sinple stott denlrite procels stryisht torard the pariphary. This dentrite branches bat spursely, and no branches are siven of tor sore listance beyond the point of its oripin. The several branches pass outard throuch the nidale layer of neurones, and the most delicate twiss can be traced into the superficial layer of nerve-fibres. The ahole dentritic series presents a top both tall and narrox, in strong contrast to the for'n assumed by the neurone of the nidile layer. Gemmules are scatterea over the branches, but thay are conspicusus neithar for their size nor their numbers. There may be other minor dendrites arising from near the base of the cell, as shorn in Fig.23; but the axone alkays takes origin fron a point suposite tho principal dendrite. The axone is directel torard tia limitzos internz. It may be traced for some distance sithout any very marked diminution of size. Vany collateral branches are given off in its course, and the ultimat? destination of the principal stem appears to be a bunlle of fibres contributing to the stratum nelullare profindim.

The boly of the cell is so largely filled with the nucleus that often only the thinnest investing film of cytoplasm is exhibitox. Six cells from this layer have their strictural features shon in Fis. 5.3, ant one of these has the thinnest envelopins cytoplasm found in this class. The nucleus of a cell is resularly oval in contoar, holjing one prominent nucleolus. The chromatic netrork is delicate and of small desh.

The cytoplasm contrins masses of tifroil substance ahich, 

in proportion to the acturl masnitude of tha cell, are ralatively large in size. When the nucleus lies towarl ane en $l$ of tha cell, the larsest tisroids are found in the frae extromity. The prevailing forn of tieroid mass is triangular, and tha several nasses have a rather open arrangement.

Erom the forn of the neurone just lescribel, we should infer that it is alapted to the part of a conductins median between the superficial and the deeper levels of the tectum wesencephali. The inter'al structure also indicates that it is characterized by no slight zmount of metabolic activity. 5vidently, then, there is hera a nervous element of considerable inportance in the econony of the nidbrian.

VanGehuchten ('34) has described the deaper neurones from tha optic lobe of the trout (his couche granuleuse) as beins aithout dendrites, and as sending their axones peripherally into the superficial levels. The character of this type of neurone in Mustelas certainly corresponds the more nearly with the conditions found in higher vertebrates, although much simpler of course, so that, in this respect at least, the selichian is seen to be in the direot phylosenetic line, while the teleost is diveræent.

In the inner zone of the deeper layer of the tectum, at the level sccupied by the numerous collaterals from the proper axones, there are to be found at intervals neurones of another character (Fis.21). Such neurones are ircéularly stellata as to generzl forn, the dendrites and the axone radiatine videly 


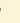


from a polyહ̧nyl cell-body. The offlice of this neurone may be to brine the collateral brunches of the other and more numerous nervous elements ints rolationship. Fis.54 shows a group of five of these cells, an unusually larşe number to find in so limitel a fiell.

\section{The Sentral Gray Vatter.}

The aguaduct of Sylvius is surrounded by a layer or nervecells and nerve-fibres representing tha most archyic part of the brain, and gito properly terned the central gray matter (Figs. 2) and 21, c. \&.m.). The frazter part of this nervous matter has been supplantea or overshadorel fiunctionally by xore recent alditions upon its sutor surface, but certain nell definez Eroups of neurones have retained their pristine importance through the character of their ultimate connections. These are, respectively, the roof-nucleus, and the nuclei of the oculomotorius and the trochlearis.

a. The Roof-llucleus.-- This is a collection of very larza neurones lying in the roof of the aqueduct of Sylvius tetween the ependyma and the dorsal commissure of the stratum vedullare profindum. The group has a considerable lonkitudinal extension, reaching from the anterior end of the optic lobes to near the juncture with the cerabollun. It is troken into tro lateral halves by the median line. His.??,r.n. exhitits the entire 

nucleus; shile Fis. 55 represents the distribution of the cells mors in letail on the right sile.

These neurjaes gre the larpest of any in the nervous organization of Mustelus. The size attrined by the cell-body nay bə as grazt as 30 micra in transvarse 1iameter by 12.$)$ micra lengthnise. The group, therafors, presents a very striking picture in the tield of the nicroscope. The torms assum31 by the cell-boties are somewhat diverse, ranging from ovyl, through inresular outlines to a considerably elongated conjition. The longer axis lies parallel, or nearly so, with tha limitans internz.

In a thick section, the denarites appoar as two or three stout processes which pash thei= Nay into the nervous matter jorsal to the group and are soon lost to view. Those cells lying very close to the metian plane sent their axones to the opposite sile; but the remaining nembers of the group, comprising nearly all of the cells, have their axones extenting away from the mid-line. The axones from the several cells of the same side, togethar with the crossed axones, run laterally for a frezter or less listance, tirn anteriorly, and become associatei into bundles which constitate a fairly well-markel truct (Figs.2) and 55, r.n.t.). This truct extends forkart to the anterior limit of the nitbrain, whers it unites aith its fellon from the opposite side, and tre unit? eroup of fibres emerses from the midbrain roof to penetrate the aqueluct of Sylvius as the fibra of Reissner. The ultinate destination will be 

traced in a subsequent parressph.

Those cells of the roof-nucleus lying in the posterior region have a different ternination for thair axones from the one just lescribad. In this instance, the axones pass posteriorly, insterd of anteriorly, and they take a course into the cereballan. Tha significance of this fact has been considarad in Section $V$, Subsection 5 .

The cell-nucleus is a large, evenly rounjed body, almost invariably eccentric in its position, sometimes, even, lyine in what appazrs to be a special protrusion of the general cellmass. The chromatin is distributed in the form of z reticulum of rather fine mesh which holds coarser Eranules at intervals. The nucleolus is evanly rounjal and of conspicuous size. Many of tha cells have tiro or even nore nucleoli.

The cytoplasm, strinəd rith methylen-blus, exhibits a minutely punctate appearance even unler the hioghest amplification, due, chiefly, to the minxte size and łiffuse distribution of the tişroid substance. The tigroids are quite densely packad in the peripheral regions of tha cell. In the field of the nucleus, the prevailing forn of Erinule is roundex; farther axay, the shape is a more elongatel one, the long axis beine tangentizl to the margin of the cell. Fig.55 shows the details of cell-orsanization, Nissl staining.

Ahen these cells gre stained with icsu haeratoxylin, they exhibit nhat appears to be the equivalent of the perinucleir reticulum of Golei (132)). We tind the internal part of the 

cytoplasm exhibitine deeply stainel, massive bodies, branchinf. and guastoussins sith eqch other through more slenler connections. The several intiviaual masses are disposed in such a xay as to give the appearance of enclosing the nucleus as $x$ it? an open netiork. The bodies fale axay as they enter the denIrites, ant there is no appearance of their having comunication with the exterior such as has been descrited by Holmsen ('э9a,'9.9b). Fis.57 represents the appeirance of this series of structures.

It is doubtless necessary to axait turther researches in many distantly related fields before we attenpt to pass final judement as to the significance of the perinuclear reticulum, but the hypothesis noted by Golgi (1900) is one which certainIy deserves our consideration. The apparance presented by the netrork may be caused, not by solia bodies at all, but by 9 series of comminicatins canaliculi filled with a fluid which is deaply colorel by certain stains. Such a raticular canalsystem xoula probably take no part in the irritable life of the cell as such, but rould finction on a loxer plane of pureIy vegetative character.

The nexrones of the roof-nucle'ss cone into intinate relations aita the nerve-fibres of the stratum medullare profundum. The dorsal decussation between the opposite halves of the stratum carries a strong bundle ot fitres across the median plane imnadiatoly above this Eroup of neurones (wis.55. dc.s.m. ., ) There are to be fount here numerous instances of 

nerve-fibres amersing from the generıl bundle and terringtins in arborizations neur the bodies of the nerve-cells. Fis.57, ar., reprasants tno such arborizations near the sume cell.

The character of the tervination is exceelingly intersstins. The axones are found to present a reticulo-vesicular stricture throughout thei whole length, the protoplasm apparently consisting of vesicles of severyl degrees of size united by $z$ reticulun. Non as the axone approzches its tornination, the reticulation becomes more pronounced, and the tinal arborization is seen to be essentially an expansion of the same thing. The ending is simply a ridely-spraat, dieitate raticulun. There are many thorn-like branches from all of the strands, and ndmerous anastomoses occur tetsean the prinaipal ones. Consult तis. 57 , 2r.

The remarkable group of nerve-cells comprising the roofnucleus has been variously interpreted, but its true ralations were not discoverət until quit? recently. Rohon ('77) first describel this collection of cells as the lachkerne, a name applied, of course, from the position occupied by its paired membars in the root of the aqueluct of Sylvius. It nas later recognized in the brains of various fishes, Eurckhardt (' 92 ) identifying it as the midbrain trigeminal nucleus. It has remained for Sargent (193)) to shon that not only is the roofnucleus present in all vertebrates, but that it is part of a most interesting mechunisa, the fibre of Reissner ('00). Reissner's fibre is a rol-like boly lyine in the centryl canal 

of the spinal corl, extenting tornara. It hat come to be neslected entirely in recent years owing to the prevalent vien that it meraly represents a coaglation of the cerabrospinal fluid. Sarsent (1900) demonstrated that such $z$ vien is erroneous, that Reissner's fibre is a raal structure, with a perfectly Jefinite character and distribution, ant, furthernors, that it is found in all classes of vertebrates, alrays extending from the postarior and of the canalis cantralis to the anterior enl of the aquedict of Sylvius. He has also shown (1901) tnat the fibre reprasants, in tha main, tha closely fused axones of the cells of the roof-nucleus. The great number of neurones corprising the antərior field of the roof-nucleus send theis axones into the zqueduct of sylvius, as noted above, whence they pass backsard as Reissnar's fibre through the extent of the fourth ventricle and the central canal of the spinal cord. Eine processes are given of $f$ to the nervous watter of the corl as tha fibre proceeds.

An interpretation of the roof-nuclexs and of keissner's fibre arising firm it may nor be attempted. In the next to the last parapraph, a nəxגs nas traced betreen the tibres of the stritum medullare protinaum and the neurones of the roof-nuclous. Thare are herə, it is evident, the elements of a tract throush which quite direct connections nay be astablishel betxeen the somatic motor neurones of the spinal cord and certain sensory impræsions, visul and olfactory, at least. The classes of impressions not?d aro carried throush the stratim medullare 

profundum to the terninal arborizations which we have jescribed near the cells of the roof-nucleus. The neurones of the roof-nucleus transmit such impressions throukh their axones, Reissner's fibre, directly to motor neurones at the severil levels of the spinal cord. The apparatis of the roof-nucleis and Reissnar's fibre, regarled as a thing apart, is axivantugeous to Mustelas because it is a path without relay, a short arc for motor reflexes between the eye and the olfactory oroan, on the one hand, and the body musculatire on the other. Ine giant size of the neurones of the roof-nucleus is douttless the correlative of not only their long axones but of their importance in the econony of the aninal, as vell. In ascending the scale of the vertebrite series, hovever, it will be found that this nechznism ever takes on a progressively less and less value, oxing to the development of other mans for attaining the same end.

b. The vucleus of the oculonotorius.-- The nucleus of the III nerve lies ventral to the gqueduct of Sylvius (Fis. 53,n.III). This collection of neurones is sharply markel oft' from all surrounding nervous elements by the large size of its cells and by the prazter intensity of stain with nethylen-blue. The Eroup extents antero-posteriorly for some distance.

The prevailing form of cell is oval, with tro or three markad extensions of outline produced by the broaily trianfular bases of the dentrites (Fig.5.). The axone is more slen- 

der by far than the Jenlrites; it is directed anay from the limitans interna, taking the course of 9 sweepine curve.

The nucleus of the cell is evenly rounded in forn, ruther larse as to proportionate size, and it has a central location. There is but a single nucleolus. The chromatin is distribıtel in a delicate network, the few interlacing strands visible being of Ereat tenuity.

The cytoplasm is remarkable for the large size of its masses of tigroid substance, these bodies being visible as distinct things even unber low amplification. The form of a tioroid is almost invariably triangular. The base of the triangle lies towarl the nucleus, the apex pointing torart one of the denarites. Those masses lying in contact with the nuclerr nembrane are somewhat brjader, takine the form of a so-called nuclear cap. The size of xass decreases toward the periphery of the cell, those lying in the bases of the dendrit?s assuming a slender form. Reference may be made to Fig.5.

The striking size attained by the nasses of tigroid substance here is doubtless associated with the purely motor function of the III nerve, the fibres of which are the zxones of these porticular neurones.

c. The Nucleus of the Trochlearis..- Rohon (.77) fell into g curious error with resaris the nucleus of the IV nerve. As is well known, the root of the trochlearis passes backara and crosses over to the opposite sile, әppesrine dorsally in the 

furrow betwaen the midbriin and the ceræbellum. Hohon evidentIy sought for the nucleus of the nerve near its superlicial orisin, for be ilentified as such a group of cella on the border of the cerabellum.

The group of neurones constituting the nucleus of the IV nerve lies posterior and slishtly ventral to the nucle's of the III nerve (Fig.53,n.IV). The anterior end of the trochlear nucleus overlaps the posterior end of the oculonotor nucleus for a short distance.

The cells of this collection are, as compared with the cells of the oculomotor nuclexs, decidedly smaller in size, and the seneral sutline is more nearly triangular. The nucleus of the call is relativaly larser in proportion to the amount of cytoplasm. The chromatic network is so delicate as to be but faintly visible even under high magnification.

The masses of tigroix substance are fen in number, relatively larşe in size, and rholly irresular as to form. There is a pərinuclear zone of cytoplasm entirely free from tigrois. it Jften appears as though many of the tigroid masses are actually clinşins to the limitins pellicula of the cell. Fif. 60 exhibits a condition typical for the cells of this Eroup.

I really an unable to offer any explanation concernine the marked differences to be observed between the tikroidbodies of the trochlear and the oculomotor neurones, respectively. The contrist in both the form and the arranpement of the tigroids is quite evilent. The distinction is a real one, 

not due to variation in the action of reasents, for I have several instances showias the marked contrast in one and the same section. A structural di:ference here is a noteworthy fact, since the tro neurones are both of the somatic motor type, entirely equivalent morphologically.

\section{The Epentyma.}

The general character of the ependyma of the midbrain is reprasented in Fis.21, ep., while Eig. 91 illustrates the details of cell-orsanization. The outline of a representative cell is somerhat lance-like, tna length four times the brazath, the pointed extremity touchine the ventricle and the greatest breadth at a point further removed. The interior of the cell is occupied almost entirely by the nucleus. It is really difficult to detect any cytoplasm at all except in a small area at the base of the ependynal fibre. The observer has the imprassion forced upon him that most of the cytoplasm during the course of Erowth has passel over into the cell-process. The stracture of the nucleus is reticulated to an almost extreme despres. Some strunds of the reticulim are relatively coarse, but nany of them are so tenuous as to lie alnost beyond the capacity of the microscope.

The ependymal fibre takes a course which is almost straioht during the first part of its length, but toxard the suter limit of the central હ̧ay matter crooked turns occur, and branches 

are given of $f$. The diameter of the process remains uniforn throushout except for slisht swellings which occur at intervals. The fibre tarminates at the periphery of the brain.

The fact that the ependynal fibre becomes irregular and branches only after it leaves the central gray matter for the newar additions outside may have a phylogenetic significance, indicating that at one time the process had no farther course than the outer limit of this most ancient nerve-substance. But it is also enticely possible that the phenomena in question are rithout such deep significance, having been cqused by the Ereater number of obstacles in the path of the fibre as it gren through the outer levels.

\section{Phylogeny of Mitbrain Stmuctures.}

The midbrain has ever been a stable part of the neural tube. Marked out early in ontogeny from the other brain-sesments, the midbrain of Mustelus retains many fextures of orsanization shich are really primitive in character.

The centril gray natter is the most archaic of the midbrain structures, and the newer ajditions of the outer levels are derivable from it. The central Eray matter is to be comparex, both as to general functions and morphological topogsraphy, to the sray matter of the spinal corl before the latter has developed its specialized cornua. In a broad way, the ventral region of each is motor, and the dorsal part a series 

of sensory centres. The homology is most readily traceable in the ventral region. The neurones of the III and IV nerves are true sonatic motor neurones, corresponding entirely to those of the ventryl cornug of the cort.

The dorsal resion of the widbrain has become more and more specialized as an optic termination. At a phylosenetically early period, the optic fitres Érew backward from their oriईinal relations to establish terminations herə. Probably the most primitive connection is the one with the giant neurones constitutine the apparatus of the roof-nucleus and Feissner's fibra. Through this means, the optic neurones vere chained diractly to the somatic motor neurones innervating the body musculature. Later, the miabrain roof became thickened by the wandering outward of neurones from the central éryy matter, and by the development of new sptic terminations associated with them. Thus bas arisen the tectam mesencephali, an endstation wich has remained important in the vertebrate series as a visual centre until secondary connections were established with the palliam. Hence the tectum is of Ereqt magnitude in the lower vertebrates, where the pallium is weak, but becomes darfed in the mammalian brain in shich there is an overshudorins development of pqlitial connections.

\section{Summary of the Vitbrain.}



all of the optic fibres, spparently only collaterul brunches being given to the interbruin. Three structural zones of the tectum are to be recosnized: the superficial, the midile, and the deeper zones, respectively. The superticial layer has chiefly fibres, with a few minate, tangentially elongated neurones. The midile layer is composel of a densely crorled tansle of neurones of the Golgi II type, the $3 x$ ones of which spread laterally. The deeper layer has neurones which send long denarites into the outer levels, while their axones penetrate the stratum medullare profundum. Optic terminations occur in all of these layers. The structure of the deeper layer places the selachian more nearly in the direct phylogenetic line than the teleost.

The stratum medullare profundum receives optic fibres, axones from the tectum, fibres of the olfactory mechanism from relays in the thalamus, as sell as fibres from posterior reßions.

The central sray matter has become differentiated at certain points to form the roof-nucleus, and the nuclei of the III and IV nerves, respectively.

The roof-nucleus is a collection of very larse neurones lying dorsal to the aqueluct of Sylvius, the axones of which forr, ultimately, the fibre of Reissner. Ierminations of fibres from the stratim metullare profundum occur near the neurones of the root-nucleus. The root-nucleus and Feissner's fibre constitut? 2 direct path for motor reflexes betaeen certain 

senses and the body musculature, involving the somatic motor neurones of the spingl cord. The senses thus meliatel are, prinarily, the olfactory and the visusl, but the acusticolateral and the generłl cutaneous systens may be represented also.

The neurones forming the nuclei of the III and IV nerves have the structure of the somatic motor neurones pertaining to the spinal cord and the otlongata.

Ependymal fibres extend throukh the entire thickness of the midbrain wall, branching but feebly. 

SESTION VII.

The Intgrbraiv.

The research of Edinger, Das Zwischenhirn, ('92), presents an account of the fibra-tracts of the interbrain of Selachii and Amphibia as demonstratel by the Weişert methol. It remains for me to add to the results of that work a description of the morphology of the neurones proper to the interbrain of Mustelus.

\section{The Thalamus.}

The thalami of a selachian ar? so saall in proportion to the other parts of the brain (Fig.1,th.) that certain of the older anatomists nere thereby caused to overlook the interbrain entirely; see section II. The small size of the thalamus is, I find, the expression of 2 lox depree of orsanizution. Several investisations have made it clear that the thalamus of a mamal has several well-defined thalamic nuclei. The thal amus of Mustelus, honever, has ramainat in a condition of such primitive simplicity that it is not practicable to institate very strict comparisons between its neurones an 3 those which are characteristic of higher forns. Before such comparisons can be of much value, a stily must be made of thalani 

having intermejiqte degrzes of development.

It has seemed to me ajvisrble to distinguish but tno collections of neurones in the thalmmus of Nustalus. One group reprasents a differentiation of the ancient central gray matter; this I have designatel the nucleus strati grisei. The other collection is certailly the one from which the several geniculate nuclei of hisher vertebrates have been derived; this I have called the nucleus geniculatum.

a. The Nucleus Stpati Grisei.-- As has just been mentionad, this collection of neurones represents a differentiation of the primitive centr»l Eray ratter. The nucleus strati grisai has retrined its oriฏinal sitation next the third ventricle (Fig.24,n.s.ङ.). It forms a broad zone just xithin the linitans interna, comprising something like one-fourth the thickness of the entire thalamus.

The aeurones of this group are the largest of the thalamus. The cell-body has a polygonal form, the several diamet ers not sreatly unequal. The dendrites radiate freely in 211 directions, but they are not very long. The nucleus of the cell has an eccentric position, causiag the cytoplasm to appear massed on the side from which the chief dendrites arise. The chromatic substance is tispose in a fen thin strunds havinE thickened nodes. The entire amount of chromatin is not great, and so the nucleus presents a lishtly stained apperrance. The tifgroif substance is limited almost entiraly to that part of the 

cytoplastn havine the sreatest mass. Some of the tiproids are altogether irresular in form and are relatively quite larose. Fis.52 exhibits tos neurones as they lie in place.

The nucleus strati grisei is the terminal station for those axones of the tructus strio-thalamicus havine their orisin in the seneral striatum. These sweep into the nucleus in bundlos, and their terminations are to be noted betreen the constituent neurones (Eig. 24,f.s.t.).

The neurones of the nucleus strati Erisei are, primarily, a ralay in the olfacto-notor chain. The tractus strio-thalanicds terminating here is one of the links of that chain, as wa shall point out in detail under Section VIII. The axones from the cells of the nucleus striti grisei pass backard into the base of the widbrain as the tractus thalamo-tectalis, and then sweep uprari into the təctum to lie in the stratim mejullare profundum. Here they are associated with other sensory nervefibres, as already noted in Section VI, and the entire sroup becomes related to the remarkable motor conducting path providad by the cells of the roof-nucleus and the fibre of Reissner. It is certainly not worth while, with the knowledge which Re have at present, to attempt an extensive comparison of the nucleus strati f̧risəi with the specialized thalamic nuclei of

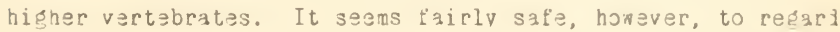
the nuclous rotandus and the nuclens masnocellularis as iescenlents of this simple collection of cells founi in the thylgmus of selachians. 

b. The Vucleus Genloulatun.-- This nucleus is imbedded in the substance of the thalamus lateral to the nucleus struti Erisai. It is separatad from the neurones of that Éroup an 3 from the external surfice of the brain by bundles of fibretracts. In trunsverse section, this collection of neurones appears as a brjad band curving parallel with the linitans externa (Fig.24, n.gen.).

The size of a neirone from the nucleus geniculatim is consilerably less than that of one from the nucleus strati Erisei, and the form is of the elongated instead of the ridizting type. Fibres from the opticus leave that nerve to form $a$ terminal zone on the periphery of the thal amus, and the dendrites of these nearsnes extend sutward into this zone, while their axones take a course intard. The neurone, therefore, comes to be drann out in a direction approximately at right angles to the limitans externa (Fig. 24, n.gen.). The cellbody is rendered somenhat elongated by the processes taking origin at its extromities. The interior of the cell is almost whally sccupied by the nucleus, leaving but a scanty amount of cytoplasm in the tases of the cell-processes (Fis.33). The chromatin is in the condition of a fine reticulum. The tifrsid substance is necessarily small in amount where ther? is so little cytoplasm, embracing only a tow scatterine granules.

Structurally consilered, the neurones of the nucleus Eeniculatum are little specialized, remainizs in an embryonic condition, so to sperk. Theic functional value is qlso of a low 

order. They are certainly of tiar less importance as an optic termination in the selachian than are their specialized representatives in the mammal. In Nustelus, only collateral branchss are, evilently, sent to the nucleus geniculatım, the Ereat mass of optic fibres sweeping backwari to the midbrain for termination in the tectam. Nith the progressive evolution of higher vertebratas, the thal amic ternination of the opticus appears to have become more and mora important, leadinp̧ to the corresponding differentiation of Eeniculate nuclei. Hand in hand witn the हrowing importance of the interbrain as a primary optic centre, honever, thera has been a related decline of the midbrain roof. And hence it is that the optic lobes of tine fish appear so disproportionately laree in comparison Nith the homologous parts of the mammalian brain.

\section{Eothalamus: The Nuclei. Habenulse.}

The auclei habenulae, or Eangliz habenulae of authors, rise considerably above the level of the thalami (Eis.1, n.h.), thə pair meating each other to form a conspicususly arohed bridge across the third ventricle at its posterior end. The epiphysis springs from the midale of the arch. The left nucleus is a little larģer than the right one, its mar@il extenlink sliehtly more anteriorly.

The nucleus habenulas is an important relay-centre, and so its structure exhibits manv nerve-fitres takine various direc- 

tions, between which thers are neurones and supporting elements. The tractus olfacto-habenularis (Section VIII, 1,c) terninates here, and the neurones of the nucleus give origin to the tructus habendo-peduncularis, (the bundle of Meynert, and the fiscicalas retroreflexus, of authors).

A representative nexrone is shown in Fis.25. The size of the entire element is rather large. The cell-body tənds to retain a rounded form, although diverted from this condition more or less by the thickened bases of the dendrites. The dendrites are some three or four in number, fnarled and irregular processes, branchine only a fen tiqes, and extendin out»ard in every direction irrar theic points of origin. The surface of a dendrite is roughened by nodal thickenings, knobs, and $a$ fen germules. The axone arises directly from the cellbody in all of the instances observed. Its course is traceable for only a short distance in a transverse section, since it soon turns posteriorly into the tractis habenulo-peduncularis. This important træct takes the usual course toward the base of the nitbrain. Its termination occurs there in the nucleus interpeduncularis. The significance of the tract is to be interpreted as a part of the olfacto-motor complex, liscussed nore particularly in section VIII.

\section{Bypothalamus: The Lobi Inferiores.}



far back beneath the milbruin; consult Fis.1. Its laree size is merely the expression of the unasual importance ahich is assumel by this part of the interbrain in selachians. Intrinsic neurones, and fibres from without are to be noted in numbers in both the infindibulum and the lobi inferiores.

The wall of the infundibulum exhibits neurones saparated from each other by considerable intervals (Fig.2f). The callbody is poly@onal or elongated-ovyl in form. The dendrites are feN in number. They spreat vilely, rarely branch, and parsue a nearly straight coursa.

The Lobi Inferiores are the nost consplcuous tieatires of the bypothalamus, a pair of Ér»at bulbous outpushings of the lateral xall of the infundibllum (fis.1, 1.i.). These lobes are the seat of a croxled sroup of neurones, a fact which is doubtless the ontogenetic cause of their large size.

Herrick ('92) has described several distinct nuclei from the lobus inferior (hypoarium) of the teleost, but I have found it impractiçble to jistinguish cell-groups in Mustalıs. The neurones are disposed in 3 layer next to the limitans interna, the cell-bodies forming a closely-packed zone involving something like the innor fourth of the thickness of the vall (Fig. 27, i.z.). The dendrites are directed sutara, forming, toEether nith the nerve-fibres here, 3 fine tungle shich presents the appearance of a molecular layer with general stuins. The form of $z$ neurone is quits anliks that of any other 

found in the anterior divisions of the bruin. It is not dissinilar to a ritely spreating bush, the cell-bady beine the short stem, and the denaritos the top (Fí.23). The denlrites are thick at their bases, they હive orişin to only a few branches, they taper gradually, and their tips usually reach almost to the limitans externa. The surface of a dendrite exhibits 9 multit'de of spiny gemales of various sizes.

The course taken by the axone lepends upon the position of the neurone. A neurone lying in the roof Eives of: its axone from the base of the cell, and the axone passes ventrally, branching profusely (Eig.27). A neurone from the siderall (Eig.23) invariably has its axone emerging from the side of the cell, taking a course toxarl the limitans externa for a short distance, then branching in a I-shaped ananer. The fibres thus formed run parallel with the sarface of the brain, one tarning into the ventral part of the lobus, the other pursuing an arcuato course sut of the hypothalamus (Eig.27, f.t.). Such a fibre is marked by varicosities at intorvals, and it bəars collzterłl branches (Fiś.2?).

The internal structare of tro neurones from the lobus inferior is ฏiven in $\$$ ig. 64. Ine fisure also shoss how closeIy these neurones are packed. The nucleus is only faicly laree, and it is surcounded by a thick lyyer of cytoplazil on all sijes. the chromatic substynce is scanty in amount; it is is isilutej in $y$ few thir strands. The tisrojd nasses sre not numerous, and most of them are quite snall, witl just a f'ex larke ones 

distributel at irresular intervals in the peripharal resion of the cell.

\section{Supoortizg Elements.}

Associatad niti tne many and cronded nerve-tracts charzctarizing the structure of the intarbrain, there is to be noted a corresponiing levelopinent of both neuroşliz and ependyma.

A neurobliar elenent has a few stout processes raliating in every direstion from the cell-body, often pursuins a markedly tortuous course. They ranify in an exceelinely complicater manner, the finəst tries intarlacins to forn a dense nat; see Fis.29. Neuroflit is found in tho nuclei or the intertrain, servins to support both the nexrones and the terminal fibres occurring there.

Ependyna is found in all parts of the interbrain. The epentymal fibra al ays extenls throushout the entice thicknes:s of nervous matter, from the ventricle to the linitans externa. The fibre branches milsay in its course, the several limbs often diversino considerıbly. The entine fibre-syster bears a dultitude of fine mossy processes. These features are shorn in Fis.37.

5. Summary of the Interbrain.

The thalamis is small in size and has ramaine on a lox plane of difforontiation. It is practicable to distinsuish 
but tirs thilamie nuclei. One, tha nucleds struti scis become lafinad from tha centril sruy instar for tha raception of tibre-tarninztions, chielly those of the tructus striothalanicus from the strixt $1 \pi$; the axones of the nuclers sive orioin to the tructus thylano tectulis. Ihe otier tnulamic nuclex, the nucleus seniculatum, receive's collataril branchos Erom optic fibres. It is aholly inferior to the tectum mesencephali as an optic teruinztion, tut it represents the spэcializol seniculate nuclei of hiogher forms.

Tha tas nuclei habenulae do not exhibit erat lisparity in size. An olfactory truct, the tractus olfacto-habenularis, terrinates here; the neurones of the nuclei sive orikin to the tractus hakenalo-0зancllaris.

The lobi inferiores are the seat of a cronled group of neurones, and the lobes are theroby given a larje size. A neurone has a ridely spreading dendritic top. Its axone branches in a $\mathrm{T}-$ shap?d manner.

Supportins elemants are stronkly levelopel. The neuroeliz is remarkable for the mat-like interlacins of its tranchas. Epentynal fibres often rinify to a strikins defroa; they extenl through the shole thickness of the neural tube. 



\section{SECTION VIIL.}

THE FORBRRAIN.

The key to the understanins of the vertebrate forebrain Nas given by Gabl-Rückhara (' $3: 3$ ) when he fornulated the thesry of the membranous pallium for the teleost. The extension of the generalization to other @roups has bəen productive of rasults shich fall into place in an almost schematic way. A quit? remarkible series is Łiven by the fishes. This series besins sith a conlition in the telesst shere the entire roof of the forebriin renzins non-nervous, and culminates in the dipnoid with a palliun havine tha essential norpholosical characters pertuining to all brains of a hisher order.

The forebrain of Mustelus appears superficially to be somenhat diversent from tho direct line of the series, onins to the absence of conspicusus external evilence of its bilaterality. The tro striata are tised topether into a soliz basal nass; thera is meraly a broad and shallox fures on the ventral side to mark their plane of contact. The pallium, while a thickenel narvaus plate as in far hisher types of brains, is perfectly continusus betreen the risht and laft sides, and it is also confluent in the melian ulan? Nith the striatz belon. 

Phese paculiarly compactel shristeristics have been th esurce of no little controversy. Stuinicks has attemptel to shon ys one of tha licta of a series of papers ('34a, '746, '95, '99) that the selachian forebrain stazds entirely apart feom that of all other vertebrates. His conclusions Nere drann from stulies on Petromyzon, and they appeir to rest upon a misconception as to the extant of the tela choroilea superior. The fallacies of his vievs have alræaly bəan pointef out ty Burckharit ('94c), anx by Eabl-Rücknari ('כ3).

The lateral ventricles and the olfactory lobes of Vastelus really anticipate the two-lobel conlition of higher forebrians in thair essantial charaeters. The lataral ventricles (Fir.1) are lerived from the outer ankles of the third ventricle, and thay pass tha lamina terninalis some distance apart from etch othar. Thei? courses lie nearly parallel throughout. Each Eives off two diverticula, the olfactory ventricle and a dorsal brinch, respectivaly. The dorsal diverticulan, (HiE.31, o.v.), is a short and narron vertical cavity for tha pallial eminence; see Subsection 4. This structure, while peculiar to the brains of certain selachians, is nevertheless of some comparative value, as aill be evilent tarthər on.

The olfactory lobes are massive proloneations of the lateral ansles of the forebrain. The primitive character of an olfactory lobe is exhibitel by the sharply lefined bilbus and tractus, and by the presence of the olfiactory ventricle (fif. 31, Jl.v.). This is a slevjer cavity lerivel ferm tha suter 
, 
sile of the lateral ventricle at the level of the pullial diverticulum.

The rocessus neuroporicas of Burckharat ( .743 ) is of such interest as to deserve especial notice. It appars superficially gs a vell-narked depression in the median plane a little anterior to the pallizl eminences (Fib.1, np.). It is rendered even more noticeable during life by the penetration of bloodVassels hera, owins to which fact kohon ('77) called it the foramen nutritiven. This structure is the vestige of a neuropore. Its ontogeny was first jescribed from the Eanoil brain by vonkupfter ('9j) as tha lobus olfactorius inpar. RablRückhard described its development in the selachian embryo ('93); and Barckharkt ('943) has ilentitiod it in many other vertebrates. The recessis neurjporicus of Mustelus retains the character of an open passage in the adult animal (Fig.31, mp.), servins as a channel for blood-and lymph-vessels. It is accompaniez by a pair of fibre-tracts, right and left, which take this primitive path from dorsum to base of tha brain; see Fig. 31 , m.s.t.

1. The Jlfactory Lobe.

It is my parpose to devote a future paper to the entire olfactory apparatus of Mustelus, and so a detail al description of the olfactory lobe sill not be Eiven hers. For the understandins of ahat follons, it Nill be sutticient to state thut, 
• 
in the bulbus, the olfactory nenrones of the first order are chyined to those of the second order throuph the usuyl tanples known as the olfactory slomerıli; and that the neurones of the second order, mitryl cells, send their zxones throush the tryctus to terninal stations described further on. Othar neurones of the olfactory lobe, havine a puroly accessory value, need not detain us at present.

\section{\%. The Striatum.}

Tha striatun is primarily a part of the olfactory apparatus, and its morphology must be interpreted with this fact in mind. Tжว ฏroups of neurones have become defined from thə હəneral mass of tha striatum for the especial reception of olfactory impressions. One of these lies next to the lateril vantricle, tha epistriatum; while tha othar one is peripheral in its location, the nucleas postolfactorius. The structure of the principal nass, or छeneral striatum, will be considered after that of the epistriatum.

a. Eoistriatun.-- The epistriatum is a sroup of neurones lyins ventral and lateral to the laterıl ventricle (üis.?1, ostr.). It comprises samething like the inner fitth of the entire thickness of the striatum. While not so sharply delititel from tha outer levels as izineer (, 32$)$ aas describod for the reptilian brain, the epistriatin of Vistol as is rayily distinfuishe 

frrom the general striatum by the siallor size und more closely crowdel disposition of its neurones. The neurones are not arranged in any definite order; they are of the Golsi II typ?, sentins their axones ventro-laterally into the striatum; ref $x r$ to Eis.32.

The call-body of such a neurone ranpes from trianoular to polysonal in outline. There are thres or four dentrites of only moderat? length. These seldom branch except near thəir bases. They bear a very fan gemmales and irregular knobs. The dendrites may extent indifferently in all directions, or they may lie tanential to the limitans interna.

The axone nay arise from the cell-body, but in many instances observal it emerses from the thick base of a lenarite. It passes into the region of the Eeneral striatum, bearine short collateral branches along its whole leneth, and altimately dividins into a wilely spreading arborization between the neurones of the outer levels. Fig. 33 shows the external features of one of these neurones.

The internal structure of the neurone is shosn in Fir. 25. The nuclaus is seen to till the erater part of the cell-boiy. It presants an oval form, and has chromatin lisposel in a fiew relatively larş masses, each consisting of a central clot xith raliatine streamers. Thera is a sinsle nucleolus. The cytoplasm lies chiefly in the bases of the larser dendrites. Its tiẹroid-todios are saall in size, few in numbor, and irresular both in forn and distribution. Judeing from the struct- 

ure presented by this neurone, it is not charucterized ty $y$ high degrrae of netabolic activity.

The epistriatum is on of the nuclei for the tarmingtion of olfactory neurones of the seconi order. Fibras also en 1 hare ahich have ascentel in the tractus strio-thalamicus, and have crossel ovar in the anterior commissure. Some of the teriainations occur near the bolies of the cells, but nany of the fibres are to be traced to z narrow zone next the lateral vantricle into which the denlrites of the neurones penetrite (Fio. 32, Jl.f.). Here the tibres Eive off branches which run parallol rith the lixitans interna. The sisnificance of tirese terminations xill be consileral under the heading of tho general striztum.

Comparing the description and fi\&ures siven by Johnston ('939) for the ganoid brain, it rould seem that the epistriztum is the more sharply narked in Vustelus. Althoubh found in an aninal ranking loxar in the zoological series, the fact is doubtless a correlative of the more ponartil olfactory orsans which characterize the selachian organizution.

b. General striatum.-- Ine median zone common to the pair of strizta contains bat $t \geq A$ naurones. It is occupiez chiefly by interlacine fibras of small calibre. The erazer number of thesa ar? doubtless commissural, tut in tha more dorsal ragion thare appeur to be connections aith tha pallium. The sreat nass of the striatum hus neirses scutterel 
throush it sithaut any orler of arransement (Hif.?1, str.). These neurones are never closely crowded, thare usually beinf *ide intervals betrean the cell-bodies. Their dendrit?s ary very lons, horavar, so that an interlacing plexus is siven throughout the shole field. FiE.34 will illustrate these festures.

An individal neurone is shown in Fie. 35 drann to a smallar scale than the other neurones of the striatum because its processes spraal so nilely. The cell-body may be rounded, oval, or polyģonal in outline. There are numerous lons and slenjer branching dendrites. Several dendrites often arise f̈rom a common thick st?m which micht almost bə consixerad a part of the cell-body. A denzrite is notenorthy t'or the many little crooks which appear in its course, and also for the peculiarly spine-like semmules which beset it. The latter fəature is eviłantly characteristic of these neurones in fishes, as Van Sehuchten ('34) has noted their presence in the trout, and Johnston $(' 98 a)$ in the sturgeon.

The all-nuclaus has its chromatin disposed in slenter, branching threwis, and in minute sranules distributel somewhat diffasely (Fig. as). Tha cytoplasm torms a thick investment to the nucleus on $a l 1$ siles. Its tieroid masses are markedly larser than those found in the neurones of the epistriatum. The larsest ones lie in the bases of the deniritos, and these have a trianfilar torm. Other masses of snaller size anl of more irrefular shape are intercalatel betaan the lar- 
. 
Eer ones. Tisroids extend into tha dendritas for a short 1istance, only.

The axone takes its oripin directly from the cell-body, So far as observel (Fig.35). It gives off collaterals durinf the first part of its length. The severıl zxones descenl to the base of the forebrain and run posteriorly in the tractus strio-thalanicus for ultimate ternination in the thalama; ses Section VII. This conșpicuous fibre-tract was describad by Rohon ('77) as the oelunculiss cerebri; by Sanders ('Z25) as the crus cerebri; and by 5 dinger in his earlier vork ('29) as the basale yorlerhirzbuliel.

The §eneral striatum has tha type of structure and the associations rhich are characteristic of motor centres. The large neurones, Nith their lons and videly spreadins dendrites, enter into $a$ nexus with the axonos derived from a parely sensory centre, the epistriatum. The latter receives, chiefly, impressions of the olfactory orker. The neurones of the striatum are indirectly affectel tirough the axones of the epistrigtum, carryins, in turn, the nervous disturbance to the intorbrain, whence a relay carries it to the freat roof-nucleus of the midbriin for direct connection vith the neurones of the body nusculature. The enornous oltiatory oréans of Mustelus indicate hox important the olfactory sense must te in the economy of the animal, and observation demonstrates tne larje place takan by olfactory imprassions in the location of food. The striatum is evidently the centre for notor reflexes, of which 
the sensory neurones chrininp the olfactory orern to it constitute one arm, and the neurones intervenine botnsen it ans the bady nusculature comprise the other.

c. Nucleus Postolfactoriss.-- The nucleus pastolfictorius is a colleation of neurones at the ventro-lateral surfiace of the striatum near its anterior end (Eis.31, n.po.). This nucleds is sharply demarcated from the óneral striatum by the closeness with shich its neurones are arranged; Fig. 26 shors the morphology of five neurones as they lie in place. The peripheral zone is sccupiet by fitres, and also by the dendritic tips of the raurones themselvas. The cell-bodies lis in a donsely mattel tanele of nervous processes just internal to the peripheral layer. A cell-kodp is somenhat larser than one from the epistriatum. The form ranges from pyranidal to elongated oval. The denarites are rather fex in number, relatively short, branching dichotomously once or trice. They are usually stout processes, Enarled, rough, and irresular, with bat fen true cammles. Some neurones send their dendrites radiately in all directions; others take a more or less tancential course; still others are extended betwean the zone of nerve-fibres at the periphary and the striatum nithin. A conspicuously felt-like tanole is thus Eiven by 911 of these interlacins dendrites.

The axone arises from one of the dendrites, so far as otserved. It passes into tho tractus olfacto-habenularis, cours- 

ins posteriorly alons the ventral borter of the forebryin for ultimate ternination in the nucleus habenulas of the interbrain; see Section VII.

The internal stractare of a postolfactory neurone is not of a pronomcet motor type. The nucleus is alnays so larre that it touches the periphery of the cell at one or more points, leaving the cytoplasm almost entirely in the bases of the denarites. The chromatin lies in a fine reticulam. There may be two nucleoli. The tigroid substance is disposed in triangular or irregular bodies of smaller size than those noted for the strigtum. These ieatures are shon in Fid.a7.

The nucleus postolfactorius recəives many olfactory fibres of the saconl orler. A fibre enterine for termination here is seen in Fie.?e, ol.f. This nucleus evilently hol is a very different plaze in the olfactory apparatus from the epistriatum. The latter appears to be a sensory Eatenay to the striatim, while the postolfactory neurones enter into linest relations Nith the posterior regions of the brain.

\section{The Vucleus veuroporicus.}

A Eroup of neurones sit dated in the region of the recessus neursporicus gुives oriein to a special bundle of the tractis strio-thalamicus, the melianbundel ot 4jinger ('23). I shall Jesişzate this Eroup the nucleus neursporicus. Ine neurones of the nucleus neurjporicus lie chiot'ly behint toe externql 

opening of the nearopore, just beneath the surtace of what is raally the most anterior part of the pallitam. Other neurones of the same eroup are found at leeper levels, in the striatum, of course. The entice group is distributed, therelore, sithout resard to the anatomicyl boundaries which we seek to dria tetacen the pallium and the striatam.

A sagittal section of the neursporic nucleus stainet by the Golsi methat exhibits a bewillerins nervous tancle. The components of this plexus are the processes of the intrinsic neurones, and the terminations of the olfactory fibres ahich sneep over from the tractus. The nucleus is seen, then, to be an axitional olfactory centre.

Tพว neuropวric neurones are shown in Fig.37, exclusive of the maze of nervous processes in shich they lie. The cellbody is large, the larsest, in tact, of any found in the forebrain. Its form is guite distinctly polysonal, the number of sides beine determined by the number of dendritos. Tne dendrites are very thick at their bases, and they are some trree to five in namber. Each one soon breaks up into large branches. The lensth of a denlrite is relatively short. Its surface exhibits thickenings and minute knobs sparingly distributed.

The axone may arise from the cell-toly, but in most instances its oriein is traceable to the thick base of one of the dendrites. The severul axones from eqch lateryl half of the zucleas ran anteriorly to the level of the neuropors, whare 

they curve upon themselves to follow the course of that channel, forming the medinubündel of 4idinger ('33); see Fis.31, n.s.t. The meliza bundles, right and left, are thus carried posteriorly and ventrally beside the recessus neuroporicus towari the base of the brain. Here erch blends with the part of the traztus strio-thalamicus takino origin from the striatum of that side, forning its central portion.

The course taken by the mexian bunile, curvinf forwari as it does to lie beside the vestige of the neurspore, is certainIy fraught rith significance. This is probably an ancient route which was at one time quite direct, but the phylogenetic enlarement of the foretrain has carried the recessus neuroporicus and the sat $\mathrm{t}^{2}$ the naurones ever farther and fiather apart.

The neurones of the nucleus neuroporicas probably function as an olfacto-motor centre, sapplementary to the chief one represented by the general striatam. The relations of this nucleus to the pallium will be discussed under the following subsection.

\section{The Pallitum.}

The neurones of the pallium lie chiofly in what are called in this paper the palltal eminences; see Fis.1 and Hif.31, p.e. I have introduced the definitive term pallizl eminence for the hamispherical roof of the jorsal diverticulam of each lataryl 

ventricle (Fis.21, p.v.). The earlier anatanists had observel the prosence of these elevations in certain selachian forsbruins, but their place in the orsanizution of the pallium hus not been recosnized heretotors. A pallizl eninence is the seat of a crowded eroup of neurones, and the elevated contition of the mass has probably arisen from the iisproportionately rapid growth which occurs hera.

The superticizl zone of a pallial eminence is occupied almost exclusively by axis-cylinders, the significance of which will be noticed presently. The neurones lie in a crowled ytasegate just vithin. Fis. 30 shors a representative group of these neurjaes. They are seen to embrace several varieties of form and size, all disposed rithout arranoenent into definite layers.

a. Neurones of the Tractis Pallii.-- The exter'lal features of the laresest variety of neurone of the pallial eminence sill be seen by referring to Eig. 2.9. This type assumes a variety of §uises, tut it is charıcterized by its larser size and by the fact that its axone enters the tractis pallii. The cell-body of such a neurone ranses from broadly oval to distinctly polygonal in fort. The dendrites are lone and xidely sprewing processes, arising throuph thick basal masses at three or four almost equilistant points. A dendrite tranches once or taice, dichotomously as a cule, and the tarningl lencths becone quite slender. Its surface is sliohtly roushened by mindte equmulos. Thes? are tar less consuicusus, hon- 


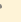


ever, thun the geminules observel in the neurones of the stristun.

The internal structure of one of these nourones is shon in Fis.63, p.t.n. The orsanizution is markedly motor in type. There is an abuniance of cytoplasm investing the nucleus on all sides. The nucleus is a sharply defined, central boly, fith a sinsle nucleolus, and chromatin which is disposed in a condition strongly suggestive of a reticulum, althagh not actually apparing so. The tigroid-bodies are quite larş in the reहion of the nucleus, the largest, in tict, of any tiscoils found in the forebriin. Nore slender tioroids extend into the dendrites for some distance. In the cell figured, the axone exhibits a sinall axona-hillock of oval fंorn.

Tì axone arises from the cell-body, (Eig.39,p.t.n.), or from the thickened base of a laroge lendrite, (Fis.39). It pursues a straight course, although one with many local sinuosities. The severzl axones of this class come to lie in the superficial zone, and they are sathared into a longitudinal bandl which lies as a broad cap on the neurone-aegregate ot the pallizl eminance (Eig.31, tr.p.). This is the beginning of the trictas pallii. The pallial tract runs backnari to the હreat posterior curve of the forebruin, whare it iips ventrally to the base and enters the interbrain. Here it decussates and passes onara tonari the oblonoata. The tractis pallit is the mant?lbünel of aijinser $(, 32)$. 

b. Assoctative anl sommissural veurones.-- A second type of neurone found in the pallial eminence is distinsuished from the preceling one by its associative or comissural vilue, and it is also readily recosnizuble by its smaller size (Fis.40). The cell-boly tends to retain a slobilar form. It ģives oriEin to tro or three dendrites which radizte fror it at equidistant points. The dendrites are only moderately stout, and they are never of @reat leneth. They branch but a fex times. Theic surfice is sparsely studied rith small semules. The axone may terminate on the same side of the briin; or it may enter the pallial comissure, (Eis.31,o.c.), for decussation, terninating in the opposite halt. The neurone shosn in Eis. 40 is an example of the comissural class.

The internal stricture of a neurone of either the associztive or the commissural type is arann in Fig. 33, as.n. The nucleus is a subspherical mass, so large that it occupies practically the rhole of the cell-body. The only cytoplasm ilstinouishable is that which composes the bases of the dendrit?s. The nucleus stains quite dəeply, oxing to the dense reticalum of chromatin shich pervales it. The cytoplaso has only a fex tiogroils of small size, an evidence ot a teeble despoe of activity for this type of neurone.

c. Sajal veurones.-. Still a thirs type of neurone is clearly the representative of the cajal cell which Ramon y Cajal ('31) described from the ceræbryl cortex of the rubbit, 

and which Retziss ('93), and Verutti ('37) have desisnatel att $3 r$ the name of the discoverar. Cajal neurones have taen observel in all of the higher vertebrates by various investizators, and their identification in the braiz of Mustelus makes it probable that they are common to all groups.

A Cajul neurona is 3 run in Eig. 41. This neurone occupies a superficial position, just beneath the stratum of fibres noted above; refer to FiE. 31. The cell-body is an irrekalarly elonoato-oval, with its major axis horizontal. From its opposite sxtremities, thick denłrites arise which run more or less nearly parallel with the limitans externa. A dentrite does not have markel turns in its course. It gives off branches along its upper nar@in which ascenl towarl the surface of the brain, while a fen branches are derived from its under side and penetrite to deeper levels. The dendritic surface bears small gemmules and larger bosses in considerable numbers.

The axone is a direct continuation of one of the denarites. Its point of origin is indicated by the surface becoming smooth and the course more irresular. Ihe axone continues to hold a course tangential to the linitans externa, and it terminates through a fen small tranches at no graat tistance from its point of orisin. This tyue of neurone is evilently purely associative, linkino together areas not Nidely separuted.

Strictırilly, the Cajil neurone is someshat peculiar (Eis. 63). The tisgroil substance is collectel into a tien lumps of relativaly larbe size. These are disposed irréxlarly in the 

Ereut masses of cytoplasin whish lie lat aril to the nucleus. The nuclers is eccentric in position, leavins but a thin pellicle of cytoplasm on one of its siles. The chromatin is grouped into a fan strands having conspicuously thickened nodes at intervals.

1. General consiterations on the Pallium..- The pallium of the selachian is really a primitive representative of the ster siving origin to the pallia of amphibians, reptiles, riris, and mammals. The continuity of its two halves, contrasted vith the tao-lobed condition of the hisher type, has caused many Nriters to rank tha salachian palliam as a diversent branch. The correctness of tne vien set forti in this peper nill qppəur when the sisnificance of the relations which exist between certain neurones of Vustelus have been considered.

It has been shown that the ventral border of a lateral ventricle is the seat of one olfactory termination, the epistriatun. The epistriatum tends to become extended around the side of the ventricle tonarl the pallixm. Axones from the marginal neurones of this olfactory centre enter the pallium, thus serving to link that resion indirectly xith the olfactory organ. Besiles this source of impressions, the olfactory centre of the nucleus neurjporicus radiates an influence to the palli:lm, of wich it is razlly a part. The pallium of vustolus, thersfory, is seen to have a eeneral association sith tha olfactory mechanism. 

It has been shorn by 4 jinper ('ga) that the special pallial olfactory confuctino path characteristic of hisher vertebrates appears for the first time in the brain of the raptile. Both filinoer and Herrick have also shown that the first sense to thus enter the field of consciousness is the olfactory one. The pallix of the selachian rally anticipates the raptilian olfactorv connection, althoroh, of course, in a much simpler way. In Vustelus, we therefore find quite y primitive condition represanted.

So far as $x \geq$ may be pərmittaz tว interpret morphological facts, the pallium of Mustelus would appear to be a lone-distance motor centre of the olfactory apparatus. Other olfactomotor centres there certainly are in abundance. Both the Eeneral striatum and the nucl ous neuroporicus contribute notor neurones to the tractis strio-thalamicas; while the nucless postolfactorius sents a tract to the nucleas habenulae. These centres obtain connection with posterior refions only through relays in both the interbrain and the midbrain. The pallium, on the othar hand, sends its tract diractly throush the base of the interbrain torard the nuclei of the great nerves of the sblongata. The trictis pallii, therefore, fives the olfactory sense an additional hold on the nervous system, a series ot connections wich cannot obtain, of course, in those fishes aith menbranous palliz.

The phylopenetic development of the pallium of selachians 1ould thus spper to be tha sutcome of the frat dependence 
which these fishes place upon the olfactory apparatus in the search for food. In hisher vertebrates, is the olfactory sense becones linked to the pyllium throush stronser bonds, an 1 gs other senses nake pallial connections, one after another, this part of the brain takes on functions of an ever hicher value. In Mustelis, there is nersly an anticipation of pallial possibilities.

\section{Suboorting Elements.}

Eoth neurobliar and ependymal elements are present in the forebrain of Vustelas.

Ependyna is found radiatine from every part of the lateral ventricle, and its characters are nearly uniform for the several reoions. The ependymal cells have their nuclei situyted at sliehtly difterent levels, and so a broad zone next to the ventricle presents chiefly nuclei. The shape of the cellbody is influenced by the position of its nucleus, of course, but the broajened part is usually not directly in contact with the ventricle. The ependymal fibre runs strwisht jutaraf from the cell-body, as a rule, and it reaches entirely to the limitans externa. It does not branch, its size remains nearly uniform, and its course is only slishtly irresular. It beurs 3 Erazter or less profision of delicate, mossy twi ss of short lensth. The inner portions of tao ependymal elements are shorn is Fis.42. 
Neuroglia is tound in the several parts of the forebrain *here nerve-cells are erouped in numbers. While the specific forms assumel by neurşliar elements exhibit considerłble diversity, all are referible to but one type. From an irregular cellboly, numerous fine processes extend in all directions for a short distance, brunching profusely as they proceed. The altimate triss are of quitaminate size, and hence it is that the shole presents a characteristically mossy appearance. Fi巨. 4? illustrates the features of a representative specimen.

\section{Summary of the Forebrain.}

A fairly well-defined epistriatum is present, receivine olfactory and other terminations. Its neurones are of the Golfi II type, sending their axones into the striatum, in the main. The axones from marsinal zones enter the pallium.

Neurroes vith sidely spreadine dendrites are arranged in open order in the striatum. Their axones enter the tractus strio-thalanicus for ternination in the thalamus. The striatum apperrs to be an olficto-motor centre.

The nacleus postolfactorius is a densely crosded group of neurones. Olfactory fibres terninate here, and the derivative axones form the tractus olfacto-habenularis.

A scoup of larse neurones in the vicinity of the recessus neursporicus sives orisin to the metian portion of the tructus strio-thalanicus. This paired tract accompanies the neuropory 
for some listance. The nuclexs neuroporicus is a third olfactory eentre.

The pallium has its two halves fused in the melian plane. Its most important region is the pair of pallial eminences. Wach of these has a special extension of a lateryl ventricle. The neurones of a pallial eminence ar» not arransed in layers, but it is practicable to recosnize three distinct forms:

(1) The neurones of the trictus pallii, the laroest variety, thair axones comorisine the tractus pallii. (2) Comissural and associative neurones, the axones of which are distributed in the pallium itselt, a special decussation of comissural fibres sccurring in the netian plane. (3) Cajal neirones, lying tangential to the limitans externa.

The pallium of Nustelis is regarded by the nriter as a primitive representative of the sten હiving orisin to the pallia of amphibians, reptiles, birds, and mammals. It anticipates the olfactory connections of the raptilian brain. The tractis pallii is interpreted as fiving the olfactory sense a hold on the nervous systen in adition to that provided by the epistriatam and striatum, and the neuroporic and postolfactory nuclei. The phylogenetic development of the pallium of selachians is believed to have been the outcome of the oreat lepondence placel upon the olfactory sense by these aninals. 
SECTION IX.

General Summary and Conclusion.

Special problems relative to the several parts of the brain have alrealy bəen discussel in the foregoing pases; ahile Summaries have baen placel at the close of each of the sections. There yet ramain for consideration a fen topics of more general scope groning out of the study as a whole. Before proceeding to these guestions, horever, it rill be desiruble to revien briefly the most important results which have been obtainel.

\section{General Summary.}

The Oblongata of Mustelus has become only slightly jiversent from the structural plan of the primitive neural tube.

The ventral cornu of the spinal cord is continued into the oblongata as tho nucleus of the VI nerve, and as the scattered commissural and tract-neurones of the fornatio reticularis.

The viscero-sensory syster has hat annexed to it a complex of paripherıl sensə-organs. The communis systen which results from this union is raprasented by components of the VII, IX, and $X$ nerves. The lobis vasi is the centre of the system. 

Hewer fibras anter the fasciculus commis than in either the teleosts or the amphibians.

The viscero-motor nucleus gives origin to the motor fibres of the V, VII, IX, and $X$ nerves. The axones enter their nerves chiefly through the medium of the fasciculus longitulinalis dorsilis. The nucleus receives impressions radiated from the lobus vagi.

The general cutaneous nucleus is the hamologue of the dorS3l cornu of the spinal corl. General cutaneous fibres, components of the $V$, IX, and $X$ nerves, terminate in both the substantia gelatinosa and the deeper part of the nucleus. Many fibres of the systen anter the spinal $V$ tract for ultimate distribution in the spinal corl.

The tuberculun acusticum is phylogenetieally young. It may have been derived from the structures of the dorsal cornu. Fibres of the acustico-lateral system terminate in tho tubarcuIun acusticum. These are components of the VII, VIII, and $X$ nerves. Neurones are present in the tuberculam acusticum of the molecular, sranular, and Purkinje types, equivalent morphologically to thase of the cerabellum.

The Cerebellun is relativoly large in Vustelus. This fact is to be interprated from the strong development of the sense of equilibrium in the animal. The stricturil plan of the cerebəllum is the same as that characteristic of higher vertebrat 3 , the differences being due to şrester simplicity of detril. 


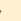


The evidence is for the orişin of the cerebəllun, in the phyloseny of the vertebrutes, as a fused outgrowth of the pair of tubercula acustica. The organ represents a specialization of that part of tha oblongata formins the original terninal station for the gcustico-lateral system.

The Viabrain appexs to have its organization arrungel contributory to the roof-nuclexs. This is a group of giant neurones, the axones of which enter into and vary largaly compose the fibre of Reissner. The roof-nucleus and Reissner's fibre, togethər xith the motor aeurones of the spinal cora, provide a direct path for notor reflaxes between certain senses and the body nusculatura. The sanses tius nediated are, primarily, the olfactory and the visual, but the acustico-lateral and the genзral cutaneous systens nay be rəpresentez also.

The stratum medullare profundum is an important highray into ahich thare are tracerble optic fibres, axones from the tectum nesencephali, fibres of the olfactory apparatus, and fibres from posterior reşions. Fibres emerşe from the stratun to terninate near tha cells of the roof-nucle'xs.

The tectun mesencephali receives practically all of the sptic fibres in Mustelus. Three zones of neurones are recognizable in the tectum, Nith optic terminations in all of them. The deepast of the three layers has a more saneralized stricture than the corresponling zone of the teleost. 
The Interbratz is the sait of several inportant relays betreen the forebriin and the posterior brain-sesments.

The thalamus is but slightly differentiated. Only tas thalamic nuclei are recosnizable. The nucleus strati grisei receives fibres, chiefly from the tractus strio-thalamicas; its axones give origin to the tractus thalamo-tactalis. The nucless geniculatım receives collateral optic terninations. It is wholly inferior as an optic centre to either the tectum mesencephali of Mustelus, or to the specializax gुeniculate nuclei of higher forns.

The two nuclei habenulae are not orextly unegual in size. The lobi inferiores are the seat of a crowded group of peculiar neurjnes.

The porebrain is regarled by the author as anticipating the forabrains of hioher vertebrates in many respects. A fiairIy nell-defined epistritum is present, the axones from which enter both the striatun and the palliun. The striatum is an olfacto-motor centre; its axones enter the tractus strio-thalmicus for tarnination in the thalzmus. An sccessory bundle of the tractis stris-thalanicus is derived from the nuclens neuroporicus. An additional olfactory centre is provided by the nucleus postolfrctorius.

The pallium has its neurones groupad, without arrangement ints layers, chiefly in the pallial eminences. Three varieties of neurones are to be distinguished. The pallium receives 


$$
\text { - }
$$


impressions radiated from the adjacent olfactory nuclei; it therefore anticipates the oltactory connections of the reptillan and higher brains. The tractas pallii, arising from the pallial neurones, is rebardel as giving the olfactory sense a quite direct connection with posterior regions.

\section{Conclusion.}

To one who has read this far, it must be evilent that there is a most remarkable structural similarity betseen the brain of Mustelus and the brains of hisher vertebrates. The results obtained by ne to not bəar out the conclusions of Szczaninsk ('93) relitive to the very low plane occupied by the selachian neurones; sea Section II, 2. The neurones of Mustelus arə, of course, simpler in their external morphology, and their architæctural relations are of a far less complicated orler, pet it is none the less true that they anticipate the conditions found in hisher vertebrates in all inportant particalars. Such $z$ fact is certæinly the more remarkable when the Erezt difterences in the scale of general orkanology are taken ints account. The fact can only be interpreted to mean that the nervous system of the primitive vertebrate had its essentials of organization vell defized before the divergence of the sevaral phyla occurred. A brain of the type presentad by the selachian of to-jay has not become sufficiently spacializel during the lapse of tine entirely to mask the ancestral charac- 

teristics. The bryin of one of the higher vertebrutes embolies many nodifications of the original plan, wrought in the course of its griluil evolution. These zlterations may even become more conspicuous than the primary structures upon ahich they have been superposed, ant it is only through comparisons with a less differentiated condition that we can hop? to distinguish the nes from the oll.

A comparative stuly of the several brain-segments of Nustelus is protuctive of some rasults that might not have been anticipatej. The cerabellan is marked by an organization out of all proportion to that of adjacent regions, an organization, moreover, far more hisghly difterantiated than is presented by the cerabellan of either the amphibian or the reptile. The oblongata, on the contrary, has retained the plan of structure of the primitive neural tube without the intervention of profound changes. It is due to this fact that homologies betreen the oblongata and the spinal cord are so raalily traced in this animal. A more extrome degुree of simplicity is found in the interbrain, the thala nus having such $z$ slight iffferentiation as to make eomparisons betwean it and high er thalani somenhat difficult. Finally, the forebrain is tar in advance of the torebrains of other fishes. Contrast the membranous pallidm of the teleost or the ganoil rith the nervous pallium of Mustalus, which, as has been pointer sut in the precedine paes, anticipates the olfaztory associations of higher brains to $a$ notenorthy degree. 

These illastrations clearly point to an underlying principle. The organizution of the brain is the expression of the adjustment ahich has constantly taken place betaean the race of animals and the stimuli to which they have been subjected. This relationship betneen nervous orşanization and pəculiarities in the enviconment is such a close one that the degree of Jevalopment of the several parts of the brain may be very unegual indes. And hence it is that the cersbellin of Mustelus is so highly orşanized, for this is the correlative of the ponarfal swimnins capacity of the aninal, requiring an adequate mechanism of equilibration. The forebrain, with its luxurious levolopment of neurones, has srisen in connection with the larş place jocupied by oltzotory impressions in tne Selachii. Norphological datz in neurology must necessarily provide the foundation for all physiological nork, but it is none the less important that morphological facts should have tho check of experimental evidence wherever this is possible. Nowhere is there to-day a more urgent nee: for careful observations of this churacter than in the group of the fishes, where nervous processes are of such a simple orler as to introduce relatively fex complications. Thorndike ('93) has male at least a besinning in this tield for the teleosts. This observer placed a scrəen with but one opening across the course in shich Fuadulus desired to sim. He found that attor severyl repetitions the animal "learned to ęt out". Hers, it would seem, thers was a trie menory of previous activities in the absence of any nervous 


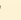


palliun at $91 \mathrm{~L}$, q very suggestive fqct in connection $\mathrm{xith}$ the interpratation placet in the present paper upon the pallium of Mustelus. An extension of the scope of experimentrl work on the tishes rill certuinly prove truitful for comparative neuroloby in so many ways that the Nriter feels impelled to bespark a larser place tor this kinf of work in our investifgations.

Since the promulggtion of the neurone concept by Naldeyer in 1391, nว Nork has demanked more critical attention than that on the ultimate tibrillar stricture of the nervous systen, studies xith which the names of Apsthy, Bethe, and Nissl rill ever be connectel. An investigation of neuro-fibrils obviously lies beyond the bounds set for the present research, and observations concerning them in Mustelus must anait another opportunity for exprassion. In the meantine, I would join with the protest made by A. Mey or ('99), Parker (1.700), and Verworn (1900) asainst the tendency to elevate the rasults of specific methods into an exclusive dogma. Although spoken from a different vantaşe-point, the Nords of Golsi (1900) may nell be quoted here: "The knosleję which we possess, either anatomical or physiological, is not yet such as to permit us to interpret Nith certainty the scæatər number of the facts discoverad, much less to attempt doctrinal constructions of $z$ high order on the functional nechanism of tha nervous elements". 
SECTION $X$.

LITTRATURE CITED.

Baer, Karl Ernst von,

37. Ueber Entaickelungsgeschichte der Thigre, Bd.2, S.303-311. Konigsberg.

Barker, L. R.

'99. The Nervous System and its Constituent Neurones. Nex York.

Betbe, Albrecht,

-96. Sine neue Metbode der Methylenblaufixation. Anat. Anzeig., Bì.12, S. $438-416$.

99. Die Locomotion des Hailisches (Seylliun) und ibre Beziehungen zu den eizzelen Gebiratheilen und zum Labyrinth.

Arch.e.d.ges.Physiol., Bd.78, S.470-493.

Burokharit, R.

-92. Das Centralnervensystem von Protopterus annectans:

Eine vergleichend-Anatomische studie. Berlin.

'24a. Die Homolgieen des $\mathrm{Z}$ wischenhirndaches und ibre Beieutung für die Vorphologie des Hirns bei neideron Vertebratea.

Anat. Anzeig., Bd.9, S. 152-155.

- 94 b. Zur vergleichenien anatomie des Vorderhirns bei Pischen.

Anst. Anzeig., Bi. 9 , S. $375-382$. 

-940. Bemerkungen zu P.K. Studnioka's Vittbeilung uber das Pischgehirn.

Anat. Anzelg., Bd.9, S. $468-489$.

- 94d. Der Bauplan ler Nirbeltheirgehirn. Morph. Arbeit., Bi.4, (.131-149.

Cox, T.H.

-91. Impragnation des centralen Nervensystens mit Quecksil bersalzen.

Archiv P.mik. Anat., Bd.37, S.16-21.

Ej inger, L.

-88. Untersuobungen über die vergleichente Anatomie des Gehirns. I. Das Vorderhirn.

Abhandl.heraus.v.d. Senckenberg.naturf.ges., B 1.15 , S. $91-113$.

-92. Untersuchungen über die vergleichente Anatorie des Gehirns. II. Das Znischenhirn.

Abhankl. beraus.v.l. Senckenberg.naturf.ges., Bd.18, S. $1-55$.

- 76 . Untersuchungen uber die vergleichente Anatomio des sehirns. II . Neue studien über das Vorderhirn der Reptilian.

Abhandl. beraus.v.i.senckenberg.naturf.ges., Bd.19, S. $313-386$.

1900. Vorlesungen über den Bau ter nervosen Centralorgane, Bte Aupl. Leipzig.

Eart, J.C.

39. On the Cranial verves of Elasmobranch Pishes. Preliminary conmunisation. Proc.Royal Society, Vol.45, pp.524-537.

92. Supplementsry Note on the Cranisl Nerres of Elssmo- 

branohs. Edinburgh.

Rechsig, P.

-89. Ueber oíne neue Parbungsmethode des centralen Nervonsystems unl teren Ergebnisse bezüglich des zusamnenhanges von Ganglienzellon unt Nervenfasern. Arch.P. Anat.und Physiol., Physiolog.Abth., S.537.

Pritsch, G.

78. Untersuchungen über den feineren Bau des Fischjebirns. Berlin.

Gaskell, N.H.

86. On the structure, Distribution and Function of the Nerves wich Innervate the Visceral and Vaseular systems.

Jour.of Physiology, Vol.7.

-88. On the Relations between the Structure, Function, and Distribution of the Cranial Nerves. Preliminary conmunisation.

Proc.Royal Society, Vol.43, pp.382-390.

189. On the Relations betaeen the Structare, Punction, Distribution and Origin of the Cranial Nerves, together with a theory of the Origin of the Nervous Systen of Vertebrata. Jour.of Physiology, Vol.10.

Gezenbaur, $c$.

70. Grundzige ier vergleichenten Anatonie,2te Aufl. Leipzig.

74. Grundriss der vergleichonden Anatonie. Leipzig.

98. Vergleiohende Anatomie der Wirbelthieremit berucksiohtigung ler Kirbellosen. Bani 1. Leipzig.

Geiuchton A. van,

- 24. Contribution a l'étude du système nerveux les té- 

1 éostéens.

La collule, T.10, P. 255-295.

Golgi, Canillo,

94. Untersuchungen uber den Peineren Bau les Central und Peripherischen vervonsystams, ubersetzt v. Teuscber. Jen a.

-88. Sur la struotire des cellules nerveuses. Arch.Ital.de Biol., T.30, p.60-71.

1900. Intorno alla struttura delle cellule nervose dells oorteccis cerebrale. Anat. Anzeig., Erganzungshept, Bi.18, S.164-176.

Grat, Arnoli,

98. On the Use and Properties of a New Pixing Fluid, ( zhrome-oxalic).

New York Stats Hospitals Bulletin.

Heitenhain, M.

'92. Deber Kern unt Protoplasna. Pestschr.?.Köl1iker, S.118.

Heli, Hans,

95. Beitrage zur Structur der Nervenzellen und inrer Portsatze.

Arob.e. Anat.und Physiol., Anat. 4 bth. S.396-416.

Herrick, C.Judson,

97. The Cranial Nervo Components of Teleosts. Anat. Anzeig., Bd.13, S.425-131.

98. The Cranial Nerves of Bony Pisbes. Jour.of Comparative Neurology, vol.8, pp.183-170.

98. The Jranial and Pirst Spinal Nerves of Menidis; A Contribution upon the Nerve Components of the Bony Pishes. 
Jour.of Compar. Neurology, Vol.9, pp.153-455.

Herriok, C. I, .

-92. Contribution to the Morphology of the Brain of Bony Pishes.

Jour. of Compar. Nourology, Vol.2, pp.21-72.

Holngren, Emil,

-99a. Zur Kentniss der Spinalganglienzellen des Kaninchens und des Frosches.

Anat. Anzeig., Bd.16, S.161-171.

- $99 \mathrm{~b}$. Weitere Mittheilungen uber ien Bau der Nervenzellen. Anat. Anzeig., Bd.16, S.388-397; Bd.17, S.113-129.

Houser, Gilbert L.

'87a. The Uses of Fornaliehyde in Animal Vorphology. Report of Iowa Acadeny of Sciences, Vol.4, pp.147151 .

97b. The Nerve-Cells of the Shark's Brain; Prelininary connuniostion.

Proceetings of the Iowa Acadeny of Sciences, Vol.4, PP. $151-153$.

Johnston, J.B.

98a. The Olfactory Lobes, Fore-Brain, and Habenular Tracts of Acipenser. Zoolog.Bulletin, Vol.1, bo.221-241.

98b. Hind Brain and Cranial Nerves of Acipenser. Anat. Anzeig., Bd.14, S. 580 -602.

Ringsbury, B.P.

-27. The Structure and Morphology of the Oblongata in Pishes. Jour.of Conpar. Veurology, Vol.7, pp.1-3e. 

Koelliker, A.

- 6 . Hantbuch der Gewebelehre les Menschen, 6te Aufl.. Bant 2. Leipzig.

Kultsehitzky, N.

87. Zur Kentniss ler modernen ixirung- und Conservirungsmittel.

Zeitscb.f.wiss. Mikr., Bd.4, S. 345-349.

Kupf $f$ er, C. von,

90. Mitteilungen zur Entaioklungsgescbicbte les Kopfes bei Acipenser sturio.

Sitzb.d.Ges.f. Morphol.u.Physiol, in Kunchen, 107123 .

Lee, Arthur Bollas,

1900. The Microtomist's Vade-Mecum, 5 th Edition. Lonton.

Lee, Prederic S.

'92. Deber den Gleichgexichtssinn.

Centralbl.f. Physiol., Bd.6, S.508.

93. A Study of the Sense of Equilibriam in Fishes. Jour.of Physiol., Vol.15, p.311.

94. A Study of the Sense of Equilibrium in Pishes, Part II.

Jour.of physiol., Vol.17, p.192.

- 98. The Punctions of the gar and the Lateral Line in $\mathrm{Pishes}$.

The Amer.Jour.of Physiol., vol.1, pp.128-144.

Lenhossek, K. von,

- 94. Beitrage zur Histologie tes Nervensystens und der Siznesorzane. Wiesbaten.

-95. Der Peinere Bau des Nervensystems, 2te Aufl. Berlin. 

Leyis, ?.

52. Beitrage zur Viikroskopische Anatomie unl Fintricklungsgeschichte der Roohen unj der Haig. Leipzig.

Meyer, Alole,

99. Critisal Review of Reoent Publieations of Bethe ant Nissl.

Jour.of Compar. Veurology, Vol.9, pp.38-45.

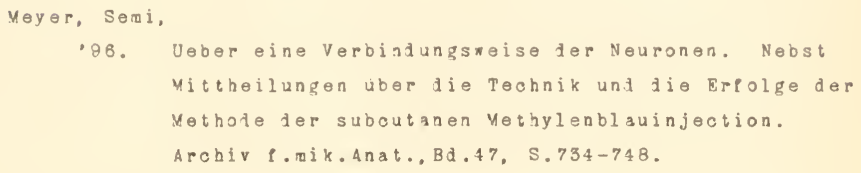

Miolucho-Maolay,

70. Beiträge zur vergleichenden Neurologie der Wirbelthiere. Leipzis.

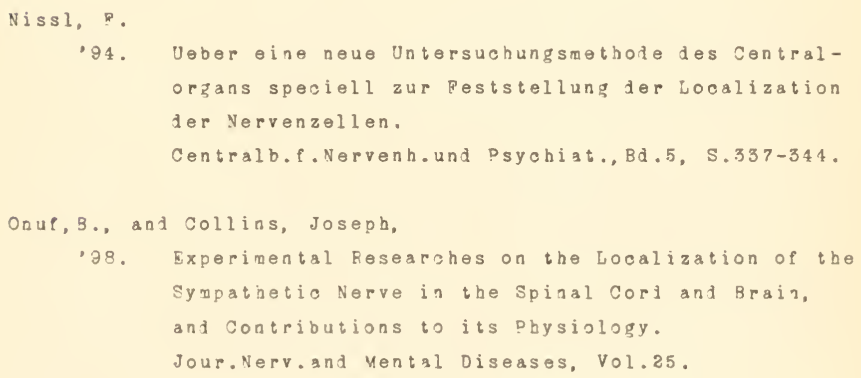

88. A Contribution to the Internal Structure of the Amphibian Brain.

Jour.of Korphol., vol.2, pp.51-96.

Parker, G. H.

1300. The veurone Theory in the Light of Peoent Discoveries. 

Amer. Naturalist, Vol.34, pp.457-470.

Rabl-Ruckhari, H.

63. Das Grosshirn ier Knocbenfiscbe unt seize Anhangsgobilde.

Arobiv f. Anat.u. Entaick, Anat. Abth., Jahrg.1983, S. 279-322.

93. 93. Der lobus olfactorius impar der Selachier. Anat. Anzeiz., Bd.8, S. 728-731.

94. Das Vorjerbirn der Jranioten.

Anat. Anzeig., Bd. 9, pp.536-547.

Ranbr y $\approx a j a l, S$.

-89. Estruotura del 16 bulo $6 \mathrm{ptico}$ je las aves y origen de los nervios bptious.

Revistra trinestral ie histol., No.3 y 4 .

-91a. Sur la structure ie l'bcorce césbrale de quelques manmiferes.

La Cellule, T. 7, p. 125-176.

91b. Sur la fine structure ju lobe optique des oiseaux et sur l'origine réle des nerfs optiques.

Inter. Monatschr.f. Anat.u. Physiol., Bd.8, Heft. 8 u. 10.

-94. Les nouvelles itees sur la structure du systeme nerveux chez $1^{\prime}$ homme et chez les vertbbre's. Paris.

96. Beitrag zum Stulium der Melulla Oblongats. Deutsob von Bresler. Leipzig.

Reissner, E.

60. Beitraje zur Kentniss vore Bau les Ruckenmarkes von Petromyzon fluviatilis. Archiv P.Anat.und Pbysiol, S.545-588. 

Retzius, G.

- 33. Die Cajal'sohe Zellen der Grosshirnrinde beim vensoben und jen Saugethieren.

Biol. Intarsuch., N.P., Bd.5.

Robon, J.V.

77. Das Centralorgan des Nervensystens der Selachier. Denksohr.d. Kaiserl. Akal. 1. Wissensoh., Wien, Yath. nat. C1asse, B1.38, S.43-108.

Sanders, Alered,

186. Contributions to the Anatomy of the Central Nervous System in Vertebrate Aninals: Plagiostonats.

Phil. Transac.Roy. Society of London, Vol.177. p p. $733-756$.

Sargent, Porter $B$.

1900. Reissner's Fibre in the Canalis Central is of Vertebrates.

Anat. Anzeiz., Bd.17, S.33-44.

1901. An Apparatus in the Central Nervous System of Vertebrates for the Transaission of Motor Reflexes arising from Optic stimuli.

Baltinore Meeting of the Amer. Morpholog. Sooiety.

Sauerbeck, Erast,

-96. Beitrage zur Kentniss von feineren Bau des Selachierhirus.

Anat. Anzeiz., Bd.12, S. $41-52$.

Sobaper, Alered,

94. Dis morphologisehe uni histologisehe Entwickelung les Kleinhirns der Teleostier.

Vorph.Jahrb.,B1.21, S.625-708.

-98. The Piner Strueture of the Selachian Cerebellum, (Mustelus vulgaris) as shown by Chrome-Silver Preparations. 

Jour. of Compar. Nourology, Vol.8, pp.1-20.

99. Zur Vorpbologie des kleinhirns.

Anat. Anzeig., Erganzungshelt, Bd.16, S.102-115.

Starr, Strong, and Leaning,

96. Atlss of Nerve Cells. Ner York.

Stieda, Ludiz,

- 73a. Ueber den Bau des Ruckenmarkes der Rochen und der $\mathrm{Hai} \theta$.

Zeitsch.f.wiss.2001., Bd.23, S.435-412.

-73b. Ueber jie Deutung der einzelaen Theile des Pischदehiras.

Zeitsch.f. iss. Zool., Bd.23, s.443-450.

Strong, 0.S.

' 75. The Oranial Nerves of Amphibiz. A Contribution to

the Vorphology of the Vertebrate Nervous Systen.

Jour.of Morphol.,Vol.10, pp.101-230.

96. Review of the Golgi Method.

Jour.of Compar. Neurology, Vol.6, pp.101-127.

Studaička, F.K.

' 94 a. Zur Losung einizer Fragen aus der Morphologie des Vorlerbirnes der Cranioten. (Vorlauf. Mitth.). Anat. Anzeig., Bd9, S. 307-320.

'94b. Eize Antmort auf die Bemerkungen R. Burakhardt's zu meiner vorlaufigen Mitteilung uber das Vorderhira der zranioten.

Anat. Anzoig., Bd. 9, S. 691-693.

95. Beitrage zur Anatonie und Entaioklungsgeschichto des Vorierhien der Cranioten. Abth.1.

Sitzungsb. d. konigl, boehmisoh. Jesell. d. Wissensch.; Matb. -Nat. Classe, No.33, S. 1-42. 

98. Nooh einige Norte zu meinen Abhantlangen über die Anatorie des Vorderbirns. Anat. Anzeig.. Bd. 14, S. $561-568$.

Szczawinska, $W$.

-98. Recherches sur le système nerveux des Sélaciens. I. Structure des cellules nerveuses. Archives de Biologie, T.15, p.463-509.

Thorndike, E.L.

99. A Note on the Psychology of Pishes. Amer. Nat1ralist, Vol.33, pp.923-925.

Veratii, E.

97. Ueber einige Structureigenthumlichkeiten der Hirnrinie den Saugethieren.

Anst. Anzeig., Bd.13, S.379-389.

Vervorn, Max,

1900. Das Neuron in Anatomie und Physiologie. Jena.

Visult, Fr.

76. Recherches bistologiques sur la structure jes Centres nerveux des Plagiostomes.

Arobiv.de Zool.exper.et gen., T.5, p.411-525.

Karriagton, $K, B$.

98. On the Structaral Alterations Observed in Nerve Cells.

Jour.of Physiol., Vol.23, pp.112-129.

Nolters, y.

90. Drei neue Methoden zur Kark- und Achsencylinierfarbung.

Zeitsch.f. . iss. Yikr.,Bi.7, S.468-173. 

SECTION XI.

DESCRIDTION OH THE FIIURES.

All of the figures have been drann with the aid of the camera lucida. A uniform scale of magnification could not be alopted because of the wile $r$ ange in the sizes of the neurones. In order that comparisons may be facilitated, the scalo $p$ diameters of the draxing as reproduced is given in the description of eacti igure. The orientation is accurately maintained in all of the draxings, the dorsal parts keing uppermost as the Pigure appears cn the plate.

\section{REFEFENCK L EITTKS .}

a. $1 .--$ Ascending $f$ ibre

a.1.f... Acustico-lateral pibre

aq.-- Aquesuct of Sylvius

ar.-- Terminal arborization

as.b.-- Associative neurote

ast.-. Astrocyte

ax.-- Axone

ax.h.-- Axone-tillock

b.f.-- Basal nerve-pibre

bv.-- Blooivessel

cb.-- Cerebellum

cb.cr.-- Cerebellar crest

cb.inf.-- Inferior lobe of the cerebellut

c. $1 .-$ Communis fibre

c.g.n.-- Central gray $x a t t \in r$

cb.-- chiasma 

c.n.-. Commissural neurone

dc. s.m.p.-- Decussation of the stratum medullare profundun

d. n.-. Deeper neurones

e.1.-- External division of the lateral ramus of the stratum medullare profundun:

๑.m.- External division of the median ramus of the stratur medullare profundur.

ep.-. Ependyma

estr.-- Epistriatum

ext.-. Linitans externa

fb.-- Forebrain

1.c.-- Pasciculus communis

1.1.J.-. Fasciculus longitusinalis dorsalis

P.s.t.-- Pibre of the tractus strio-thalaricus

g.c.f.- General cutaneous fihre

g.c.n.- General cutaneous nucleus

g.1.-- Granular layer

hy..- pypophysis

III.-- The oculomotorius

i.1.- Internal division of the lateral ramus of the stratux nedullare profundug:

i.m.- Internal division of the median ramus of the stratum medullare profundum.

inf..- Infundibulum

inf.v.-- Ventricle of the infundibulum

int... Limitrus interna

IX.- The glossopharyngeus

i.z..- Inner zone

1.i.-- Lobus inferiar

l.v.-- Lateral ventricle

1.vg..- Lobus vagi

mb..- yijurain

a.f.-- Median nerve-fibres, longitudinal bunde

m. f:- - Yedian nerve-pibres, transverse bundle

m.1.-- volecular layer

m.n.-- viddle neurones

n.s.t.- Vedian bundle of the tractus strio-tbalaticus

n.

n.gen.-- Nucleus geniculatux 



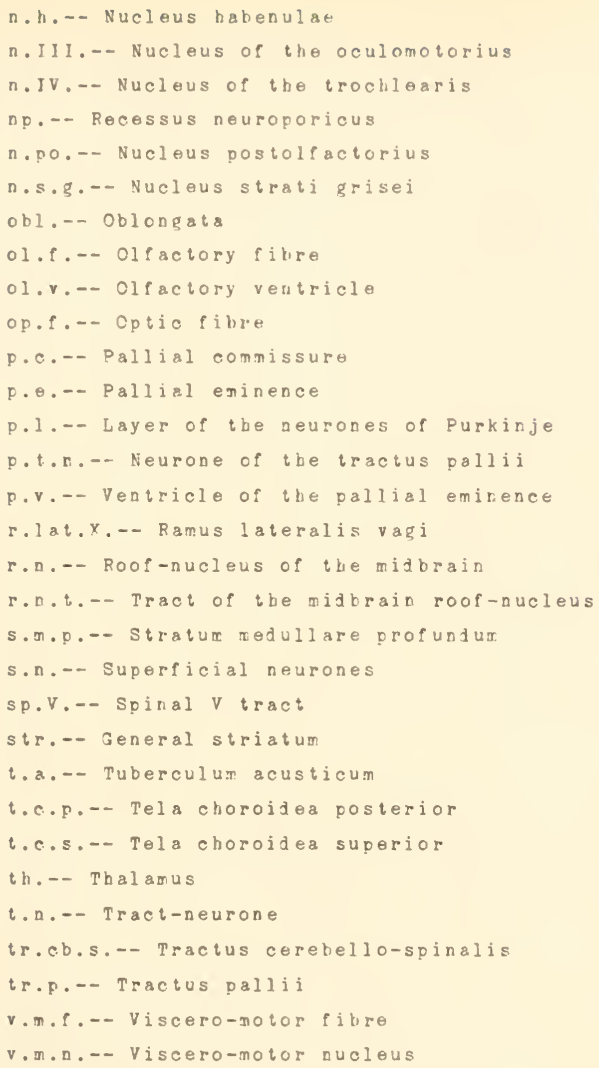

PLATH, I.

Pig.1. Vedian sagitbl section through the train of an adult vustelus. The right lateral vetiricle of the forebrait is indiczted in broken outline. vatural size. 
Pig.2. Composite transverse section of the oblongata at tbe level of the IX nerve. The Golgi retbod. Outline $\times 14$.

Pig.3. Structural elements from the formatio reticularis on the right side of the oblongata. The comissural neurone (c.n.) sends its axone across the redian raphe. The upper neurogliar cell ( $\mathrm{ng}$.) bas its longer axis extended ir the radius of tbe oblongata. The Golgi retbod, $\times 230$.

Pig.4. Two Deurones from the lobus vagi of the oblongata, and a communis fibre (c.f.) having its terminal arborization near a cell not drawn. The axones are directed in to the deeper nervous natter. The Golgi method, $\times 230$.

Pig.5. Oblongata; a small area from the substantia gelatinosa of the general cutaneous nucleus. The minute neurone (a) has a profusely branching axone, with which the dendrites of (b) interlace to form a complex tangle; in this, the general cutaneous fibre (g.c.f.) has its ternination. The axones of (b) and (e) penetrate the deeper levels of the nucleus. The Golgi method, $\times 230$.

Pig.6. Oblongata; a neurone from the deeper part of the loft general cutaneous nucleus. A general cutaneous fibre (g.c.p.) is seen breakirg up into a terminal arborization. The Golgi methoi, $\times 230$.

Pig.7. Oblongata. Tro purkirje neurones from the cerebellar crest of tbe tuberculua acusticum. An acustico-lateral fibre (a.l.p.) is seen terminating near the one on the right. The Golgi method, $\times 230$.

Pig.8. Oblongata; ependyoal ibres from the outer level of the general cutaneous nucleus. The Golgi method, $\times 230$.

Pig. . Ependy formitg a bundle ir tbe formatio reticularis. Tbe Golgi retbct, $\times 230$. 
Pig.10. Ependyma from the lobus vagi of the oblongata. The Golgi method, $\times 230$.

Pig.11. Neuroglia cell from the general cutaneous nucleus of the oblongata. The Golgi rethod, $\times 230$.

$$
\text { PLA A' h. II . }
$$

Pig.12. Sagittal section through the entire cerebellum showing its folds, the form of its ventricle, its neurone-layers, and its prircipal masses of nerve-fibres. The Folters metbod. Outline $\times 3$.

Pig.13. Neurone of Purkinje from the cerebellum. The Golgi rethod, $\times 230$.

Pig.14. Neurone from the molecular lays of the cerebellum. The greatest extension of the dendrites is parallel with the surface of the cerebellar fold. The Golgi method, $\times 230$.

Pig.15. Three representative neurones from the granular layer of the cerebellum. The intervening cell-bodies are oritted for the sake of clearness. The axones are cut across at the juncture of the granular with the molecular layer; see Pig.16, and the description in the text. The Golgi metbod, $\times 230$.

Pig.16. Axones in the molecular layer of the cerebellum passing transversely across the organ, derived from the neurones of the granular. Several ascending axones are to be seen just previous to their T-shapej division. The Golgi method, $\times 230$.

Pig.17. Neurone of the Golgi II type from the granular layer of the cerebellum. The solgi method, $\times 230$. 

Pig.19. Neurogliar cells from the cerebellum. The cellbodies lie betneen the neurones of Purkinje. An astrocyte is seen at (ast.); and a Bergmann's fibre at (bg.f.). The Golgi method, $\times 230$.

Fig.20. Transverse section of the midbrain. The Folters method, $\times 11$.

Pig.21. Transverse section of the entire thickness of the left optic lobe, shoxing the neurones of the tectum mesencephali. The Golgi method, $\times 46$.

PLAI'E III.

Pig.18. Ependymal elenents from the cerebellum. Por the sake of clearness, only a few of the fibres proper to tbe region bave been represented. The Golgi metboj, $\times 230$.

Fig.22. Neurone from the middle layer of the tectum mesencepbali. The Golgi method, $\times 300$.

?ig.23. Neurone from the deeper layer of the tectum mesencephali. The Golgi nethod, $\times 230$.

Pig.24. Interbrain. Transverse section through the left thalamus at the level of the chiasma. The jotted lines indicate tbe extent of the tbalamic nuclei. The Golgi metbod. outline $\times 30$.

Pig.25. Interbrain; a neurone from the nucleus babenulae. The solgi netboj, $\times 230$.

Pig.28. Interbraic. Tro neurones from the right sije of the infundibulum, together aith the structures ajjacent to them. The Golgi nethos, $\times 16$. 

Pig.27. Interbrain. Transverse section of the right lobus inferior. The Golgi metbod. Outline $\times 30$.

Pig.30. The inner balf of an ependymal elerent from tbe hypothalamus. The Golgi method, $\times 150$.

PLA I' F. IV.

Pig.28. Neurone of the hypothalanus from the right lobus inferior. The T-shapej branching lies parallel with the limitans externa. The solpi method, $\times 230$.

Pig.29. Neuroglisr element from the nucleus habenulae. The Golgi nethod, $\times 230$.

Pig.31. Condosite transverse section of the forebrain. ?ho solgi methol. Outline $\times 9$.

Pig.32. A small area from the left epistriatur. The neurones send their axones into deeper levels. The Golgi method, $\times 4 \in$.

Pig.33. Neurone from the right epistriatum, its axone passing into the general striatum. The Golgi method, $x 230$.

Fig.34. An area from the left general striatum to show the arrangement of the neurones. The Golgi method, $\times 46$.

Pig.35. Neurone from the general striatum. The Golgi netbod, $\times 150$.

PLATH, V.

Pig.36. A siall area of the nucleus postolfactorius to 

show the character and arrangement of its neurones, together xitb the termination of an olfactory fibre. The Golpi metbod. $\times 230$.

Pig.37. Two neurones from the nucleus nouroporicus. The section as taken in the sagittal plane. The Golgi metbod, $\times 230$.

Pig.38. A group of neurones from tbe right pallial eminence. The Golgi netboj, $\times 87$.

Pig.39. Neurone from the right pallial eminence. Its axone finally enters the tractus pallii. The Golgi dethod, $\times 230$.

Qig.10. Neurone fron the right pallisl eminence sending its axone into the pallial comissure. The Golgi rethod, $x 230$.

Fig.41. A neurone of cajal from the left pallial eminence. The Golgi netbos, $\times 230$.

Pig.42. Ependyma from the left striatur. The fibres really extend entirely to tbe lixitans externa, but only the inner portion has been represented. The Golgi method, $\times 230$.

Pig.43. Neurogliar element from the pallial eminence. The Golgi methos, $\times 230$.

PLAT'E VI.

Pig.44. A tract-neurone lying just to tbe left of the nejian raphe of the oblongata, sending its axone into a tract of the opposite size. The Nissl methos, $\times 800$.

Pig.45. Commissural neurone from the right side of the oblongata; its axone passes to the left across the median rapho. The Nissl xethod, $\times 1120$. 

Pig.46. Neurone Prom the right lobus vari. The Nisal metbod, $\times 1120$.

Pig.47. Neurone from the right viscero-motor nucleus of the oblongata. The axone passes dorsal to the paseiculus communis on its ay to the pasciculus longitudinalis dorsalis. The Nissl methol, $\times 900$.

Fig.48. Oblongata. Tro of the deeper neurones from the rigbt general cutaneous nucleus just dorsal to the lobus vagi; tbey lie between the bundles of tbe spinal $V$ tract, indicated in outline. The Nissl Ietbod, $\times 1120$..

PLATE VII.

Pig.49. Tao Purkinje neurones from the ceretellum. The Nissl notbod, $\times 1120$.

Pig.50. Tro Deurones from the nolecular layer of the cerebellum. These lie unusually close together. The Nissl metbod, $\times 1120$.

Fig.51. Pive beurones from the granular layer of tbe cerebellux. A nerve-fibre is seer ascending between tbem to tbe molecular layer. The Nissl method, $\times 11 z \alpha$.

Pig.52. Neurones of the superficial and middle layers of the tectur mesencephali. The Nissl method, $\times 900$.

Fig.53. A group of the spindle-shaped neurones characteristic of the deeper layer of the tectum resencephali. The Nissl methoi, $\times 800$.

?ig.54. A group of the stellate beurones found at intervals in the deeper layer of the tectux resencepbal1. The Nissl nethod, $\times 800$. 

Pig.55. The region immediately dorsal to the aqueduct of sylvius, shoring the disposition of tbe neurones of tbe roofnucleus. Metbylen-blue, $\times 89$.

Fig. $5 €$. Neurone from the left balf of the midbrain roofnucleus. The Nissl retbod, $\times 900$.

Pig.57. Neurone from the roof-nucleus of themidbrain, rigbt side, together nitb a part of the stratum medullare profundun. Two fibres are seen to emerge from the stratum to end in arborizations near the neurone. Iron haematoxylin staining. Outline $\times 486$; details from the homogeneous immersion.

PLAIL. VIII.

Pig.58. Midbrair. Sagittal section through the nuclei of tbe oculomotor and trochlear nerves. Methylen-blue, $\times 88$.

Pig.59. Neurone from the nucleus of the II nerve. The tigroid masses in the region of the nuclear membrane are remarkable for their large size. The Nissl method, $\times 800$.

Pig.80. Neurone from the nucleus of the IV nerve. The Nissl netbod, $\times 1120$.

Pig.61. Ependyma from the optic lobes. The ependymal pibres are represented to the boundary of the ceatral gray mat $t \in r$, only; see Pig.21 for the entirefirre. Combination of iron baematoxylir and metbylen-blue staining, $\times 1120$.

Fig.e2. Interbrain. To neurones from the nucleus strati grisei of the tbalaus. The Nissl metbod, $\times 1120$.

Pig.63. A characteristic zroup of neurones from the nucleus geniculatum of the thalarus. The Nissl method, $\times 1120$. 
- 
Fig.e4. Tro neurones from the left lobus inferior. Their dendrites are directed toward the limitans externa. The Nissl method, $\times 1120$.

Pig.65. Porebrain. A group of three neurones from the epistriatum. The Nissl xethod, $\times 1120$.

Pig.66. A neurone of the general striatum. The Nissl wethod, $\times 1120$.

Pig.67. A group of five neurones from the nucleus postolfactorius. The Nissl method, $\times 1120$.

Fig.68. Neurones from the left pallial eminence. The neurone of the tractus pallii (p.t.n.) sbows an axone-billock. The smaller neurone (as.n.) is of the associative type. The Nissl netbod, $\times 1120$.

Pig.68. Cajal aeurone from the lateral part of \& pallial exinence. The Nissl metbod, $\times 1120$. 
LH'E.

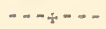

I, Gilbert Logan Houser, was born on an Iora farm in 1333. Vy preparatory training ras given by several academies and colleges not far from home. Entering the University of Iowa, I pursued an underşratuate course in that institution for four years, receivine the degrae Bachelor of science in 18991. A year was subsequently spent in graluate study at the University of Ioxa, laading to the deşree Waster of Science, 1892. My Erijuate studies have since been contiqued in connection with the Iniversity of Chiczso an 3 the Johns Hopkins University. My earlier investigations nere chiefly in the fields of seology and paleontology. The diszertation for the Naster's jeşree as a critical study of the "Genera of Paleozoic Corals of the Order Madreporaria". Later, the Iowa Geological Survey crmmissioned me to examine certain building-stones and limeburning rocks of eastern Iosa; my report on this subject is published in the Report of the Iora Geological Survey, Vol.I. Receivins an appointment as Instructse of Biology in the University of Iona, my studies have since floned entirely in biological channels.

A biological expedition to the Mest Inlies of thros montis, and four season's sork at the Marine Biolosical Laboratory of 

Woods Holl have proviled both the opportanity and the inspiration for the pursuit of numerous researches. Two papers have been published as the rasult ot these stajies:-- "The Jses of Eornaldehyde is Aninal Norphology", and "The Nerve-Vells of the Shark's Brain".

Since my appointment as an Instructor in 1392, the University of Iowa has हradually advalucel ne to positiols of larßer and larger responsibility, culninating in my election to the Professorship of Animal Morpholoby and Physioloky in June 1897. a position which I still hold. At my urgent request, I was Eranted leave of absence in September 1900 for a year of graduate study. I have chosen to spend that year at the Johns Hopkins Jniversity.

I hold membership in The 4nerican Morpholosical Society, The American Society of Naturalists, and The Iora Academy of Sciences.

Baltinore, May, $1 \ni 01$. 















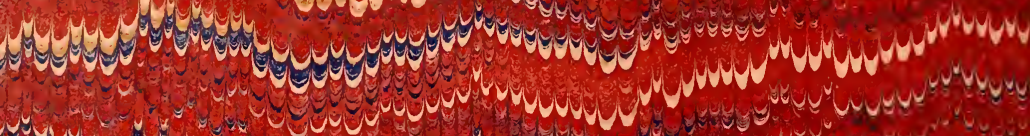

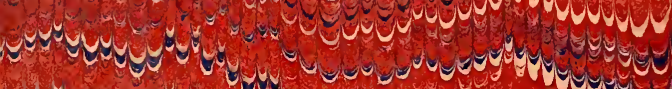

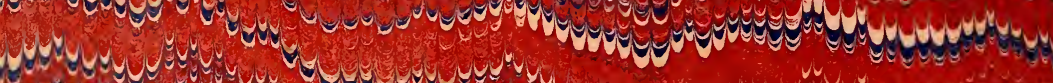

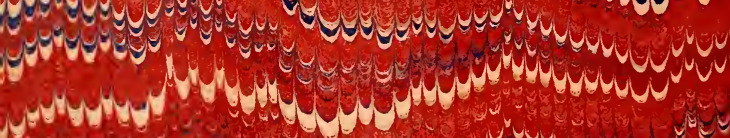
yovilyol

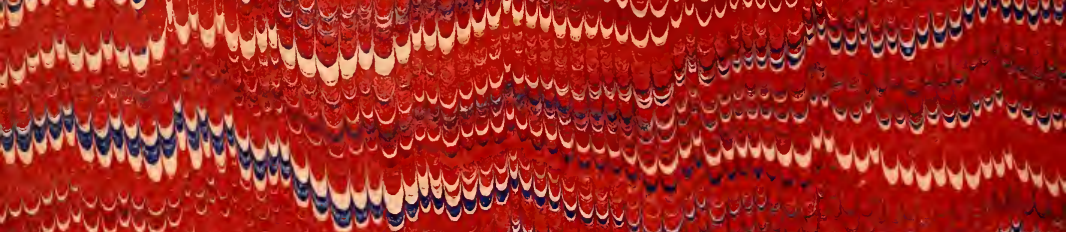

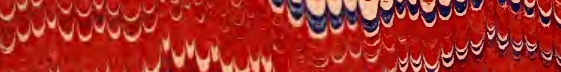

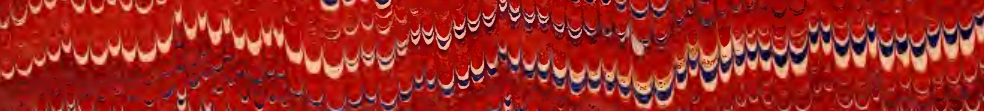

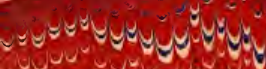

geo

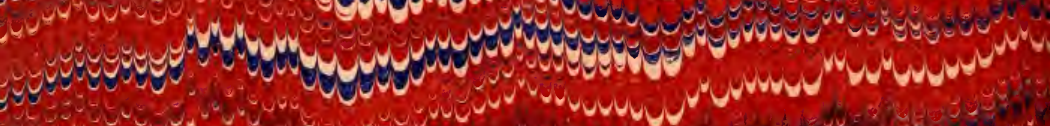
2000

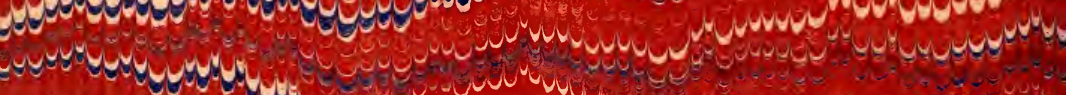

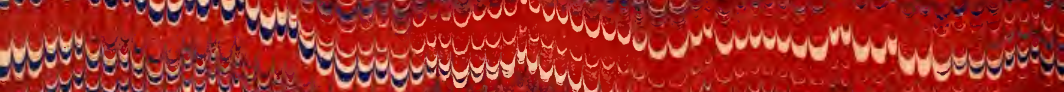

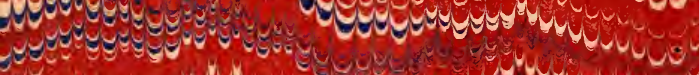

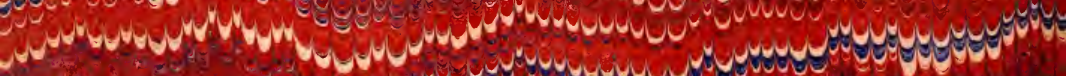

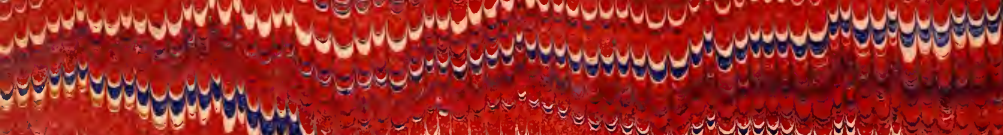

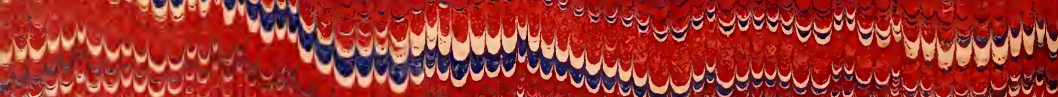

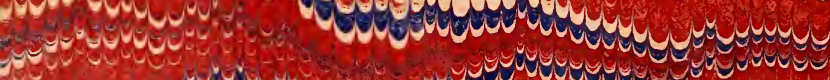
gevereg 
sum

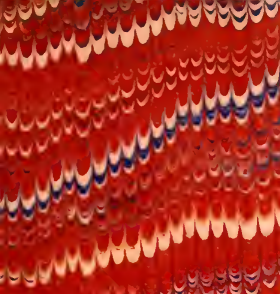

gyoy

M

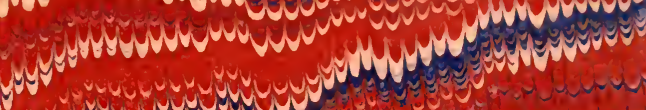

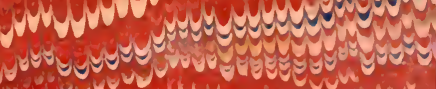

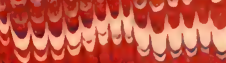

Mil yavaryas w yove ryy $y$ y woyys

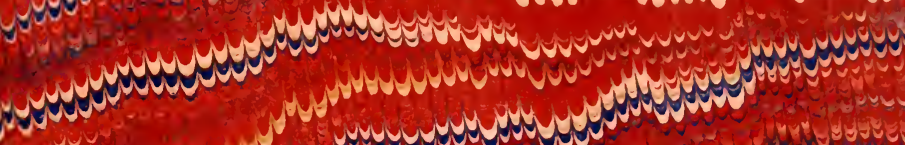
ctom

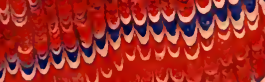

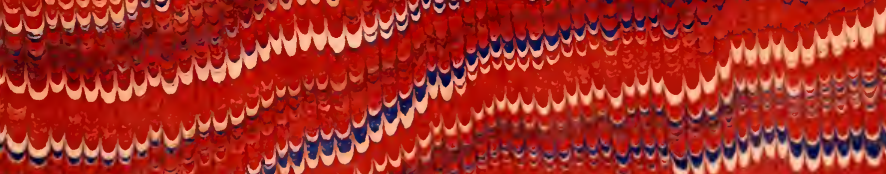

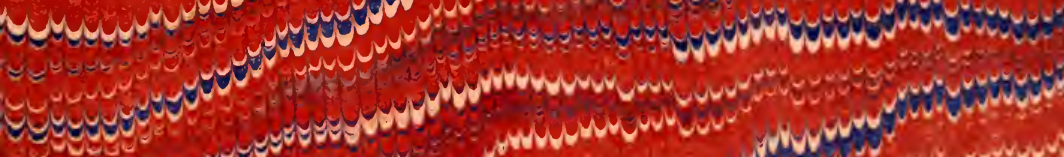

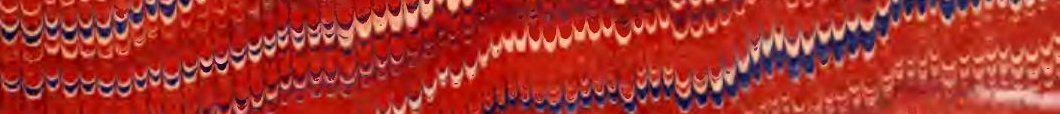
Co

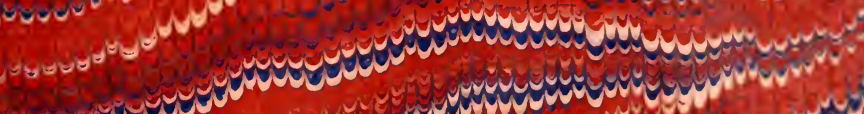
Y. -

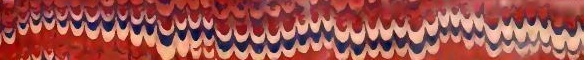




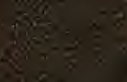

$\cos \pi=3$

39

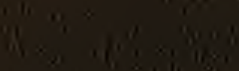

$10 \times 6$

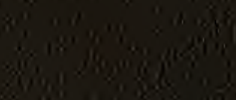

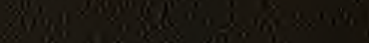

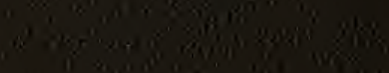

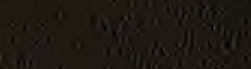

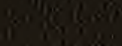

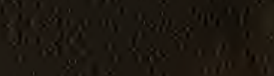

$+30$

anomgon

$55^{1}+4 \times 2$

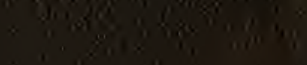

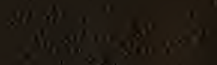

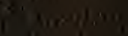

$3)^{\circ}$ 